\title{
COMBINATION OF SONOPHOTOLYSIS AND AEROBIC ACTIVATED SLUDGE PROCESSES FOR TREATMENT OF SYNTHETIC PHARMACEUTICAL WASTEWATER
}

\author{
by: \\ AMIR MOWLA \\ B.Sc. in Chemical Engineering \\ Shiraz University, Shiraz, Iran, 2011
}

\author{
A thesis \\ presented to Ryerson University \\ in partial fulfillment of the \\ requirements for the degree of \\ Master of Applied Science \\ in the Program of \\ Chemical Engineering
}

Toronto, Ontario, Canada, 2013

(C) Amir Mowla, 2013 


\section{AUTHOR'S DECLARATION FOR ELECTRONIC SUBMISSION OF A THESIS}

I hereby declare that I am the sole author of this thesis. This is a true copy of the thesis, including any required final revisions, as accepted by my examiners.

I authorize Ryerson University to lend this thesis to other institutions or individuals for the purpose of scholarly research.

I further authorize Ryerson University to reproduce this thesis by photocopying or by other means, in total or in part, at the request of other institutions or individuals for the purpose of scholarly research.

I understand that my thesis may be made electronically available to the public. 


\title{
ABSTRACT \\ Combination of Sonophotolysis and Aerobic Activated Sludge Processes for Treatment of Synthetic Pharmaceutical Wastewater
}

\author{
By: \\ Amir Mowla \\ Master of Applied Science \\ Chemical Engineering \\ Ryerson University \\ (C) 2013
}

The treatment ability and efficiency of sonophotolytic process, aerobic activated sludge (AS) process, and their combination in reduction of total organic carbon (TOC), total nitrogen (TN), chemical oxygen demand (COD), and biological oxygen demand (BOD) from a synthetic pharmaceutical wastewater (SPWW) were studied. Batch mode experiments were performed to obtain optimal experimental operating conditions for sonophotolysis process. Ultrasonic power of $140 \mathrm{~W}$, initial $\mathrm{pH}$ solution of 2 , and air flow rate of $3 \mathrm{~L} / \mathrm{min}$ were found as optimum. The initial optimum molar ratio of $\mathrm{H}_{2} \mathrm{O}_{2} / \mathrm{TOC}$ was found to be 13.77 for sonophotolysis process alone in batch mode. In continuous mode, sonophotolysis was able to reduce TOC by $90 \%$ after 180 min retention time. Aerobic AS process alone after $48 \mathrm{~h}$ retention time reduced TOC by 67\%. Combined sonophotolysis and aerobic AS processes improved the biodegradability of the SPWW and resulted in 98\% TOC and 99\% COD removal while decreasing the retention time in sonophotoreactor and aerobic AS reactor to $120 \mathrm{~min}$ and $24 \mathrm{~h}$, respectively. Additionally, the consumption of $\mathrm{H}_{2} \mathrm{O}_{2}$ was reduced significantly in the combined processes. 


\section{ACKNOWLEDGMENTS}

I would like to express my sincere thanks to my primary supervisor, Dr. Mehrab Mehrvar, and my co-supervisor, Dr. Ramdhane Dhib, for offering me the opportunity to study and work in their research group. Their continuous guidance and financial support during my graduate studies are highly appreciated.

I am very thankful to the Engineering Specialists of the Chemical Engineering Department, Ali Hemmati, Daniel Boothe, and Tondar Tajrobehkar, for providing invaluable assistance during the experimental set up.

I would also like to express my gratitude to my parents (Dariush and Giti) and my brothers (Arash, Ashkan, and Omid) for their love and support earlier and during my studies in Canada. I would like to name Samira Ghafoori, Leila Pakzad, Meysam Alian, Ciro LeCompte, Masroor Mohajerani, Roghayeh Babaie, Dinesh Patel, Dina Hamed and Mohsen Nasirian who were nice lab-mates for those times we shared in Wastewater Treatment laboratory. I would like to acknowledge my dear friends Navid Hakimi, Saeedeh Abedidoust, Samin Eftekhari, Sayeh Azar, Nasim Hashemi and Amin Alavai in Toronto for their genuine friendships. Finally, I acknowledge Natural Sciences and Engineering Research Council of Canada (NSERC) for the financial support during this work. 


\section{TABLE OF CONTENTS}

AUTHOR'S DECLARATION FOR ELECTRONIC SUBMISSION OF A THESIS.............ii

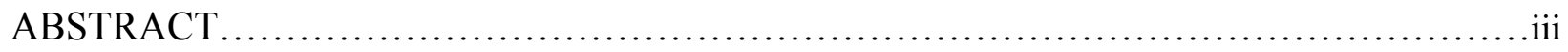

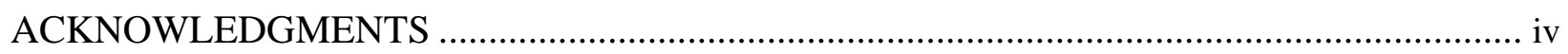

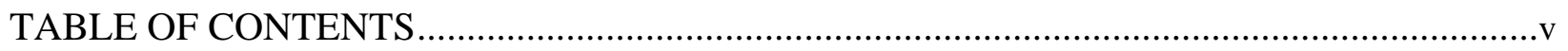

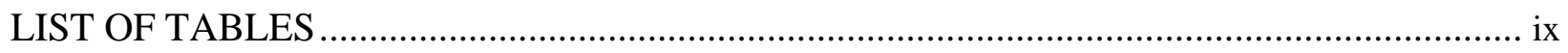

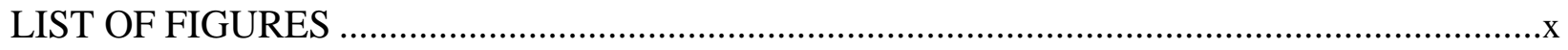

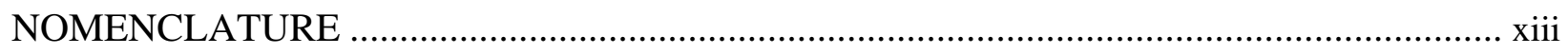

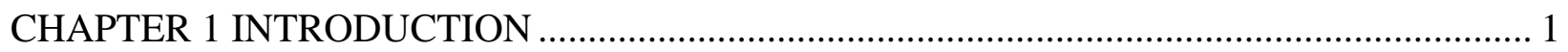

CHAPTER 2 LITERATURE REVIEW ........................................................................ 5

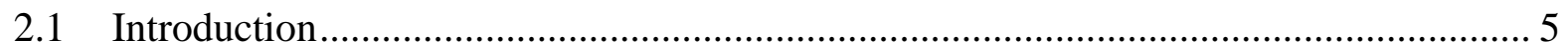

2.2 Characteristics of Pharmaceutical Wastewaters ...................................................... 5

2.3 Occurrence and Fate of Pharmaceutical Wastes in Environment .............................. 7

2.4 Environmental Effects of Pharmaceutical Contaminants ...................................... 10

2.5 Regulations and Discharge Parameters of Pharmaceutical Wastewater Effluents ....... 11

2.6 Pharmaceutical Wastewater Treatment Technologies .......................................... 15

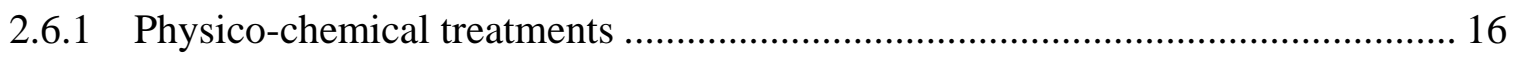


2.6.2 Reverse Osmosis and nanofiltration ................................................................. 16

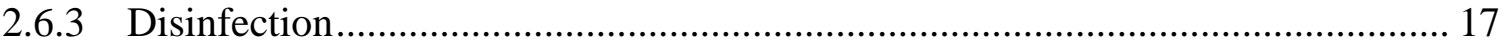

2.6.4 Biological wastewater treatment................................................................... 18

2.6.5 Advanced oxidation processes (AOPs) .......................................................... 20

2.6.6 Combination of advanced oxidation and biological processes for wastewater

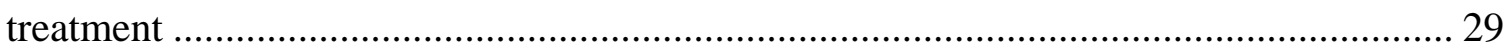

2.6.7 Parameters for measuring biodegradability of wastewater samples ...................... 31

2.6.8 Concluding remarks ................................................................................... 32

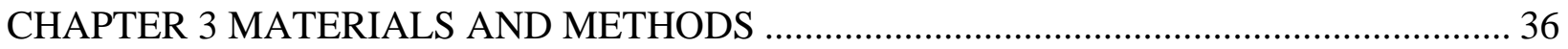

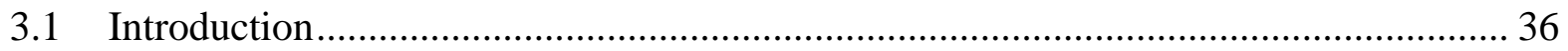

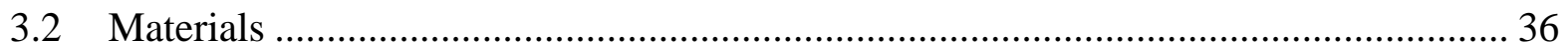

3.2.1 Synthetic pharmaceutical wastewater (SPWW) ............................................... 36

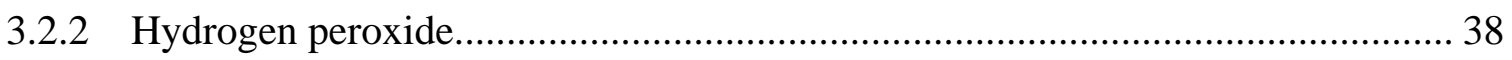

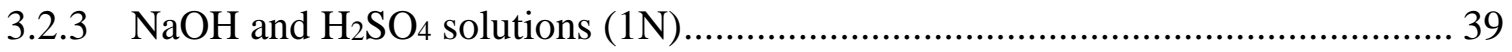

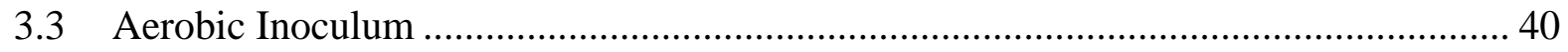

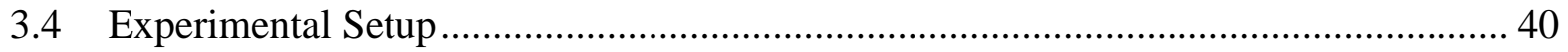

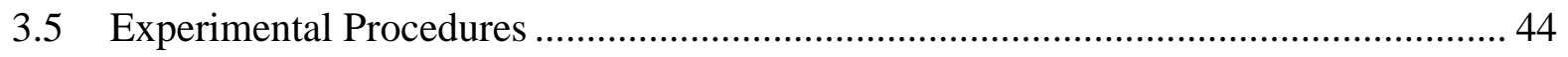

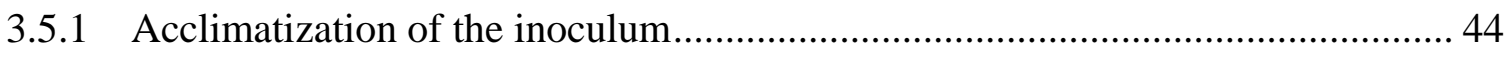

3.5.2 Aerobic activated sludge process ..................................................................... 44

3.5.3 Photolytic, sonolytic, and sonophotolytic processes in batch and continuous

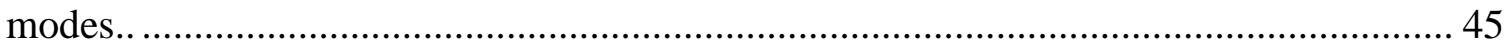

3.5.4 Combined UV/US/ $\mathrm{H}_{2} \mathrm{O}_{2}$ and aerobic AS processes .......................................... 47

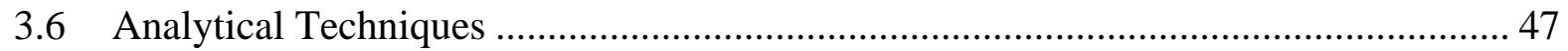

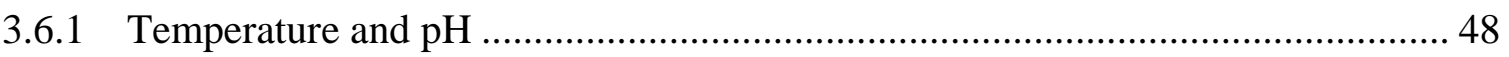

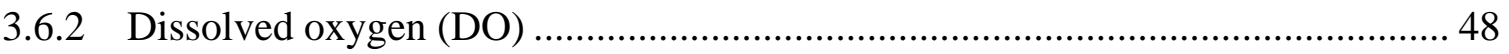

3.6.3 Mixed liquor suspended solid (MLSS), mixed liquor volatile suspended solid (MLVSS), Total suspended solid (TSS) and Volatile suspended solid (VSS) ................. 49 


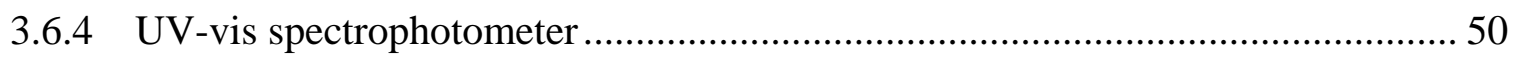

3.6.5 Chemical oxygen demand (COD) measurement .......................................... 51

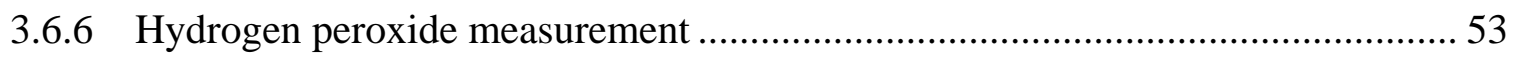

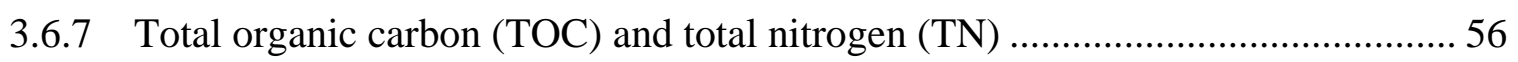

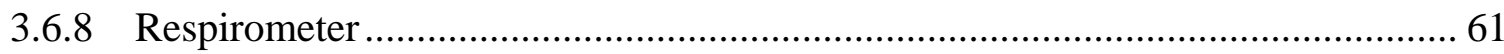

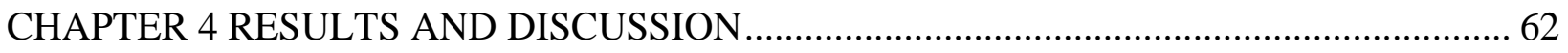

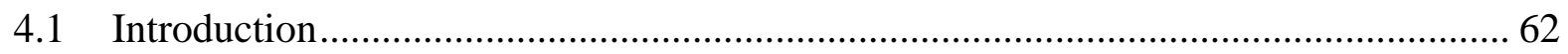

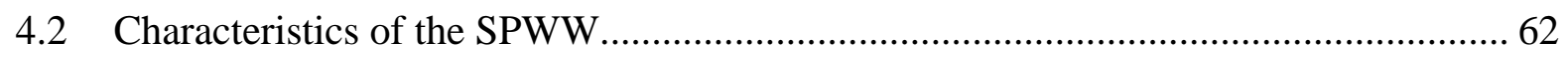

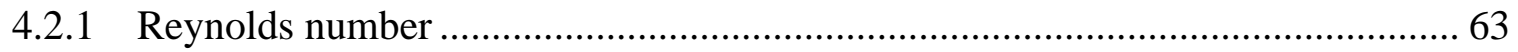

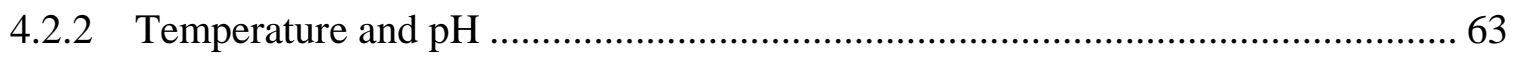

4.2.3 MLSS and MLVSS concentration of the aerobic activated sludge .................... 64

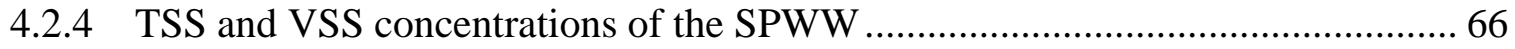

4.3 TOC Removal in SPWW Using UV/US/ $/ \mathrm{H}_{2} \mathrm{O}_{2}$ Process Alone in Batch Recirculation

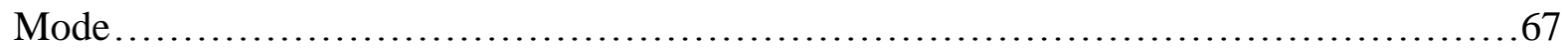

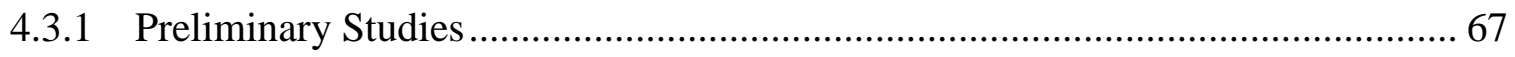

4.3.2 Optimum operating conditions for UV/US/H2O2 process ............................. 71

4.4 TOC, COD, and TN Removal in SPWW Using Aerobic Activated Sludge Process ... 84

4.5 TOC, COD, and TN Removal in SPWW Using Combined UV/US/ $/ \mathrm{H}_{2} \mathrm{O}_{2}$ and Aerobic

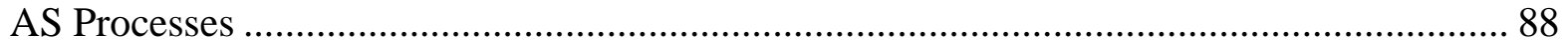

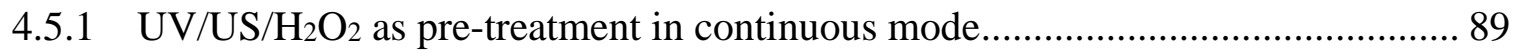

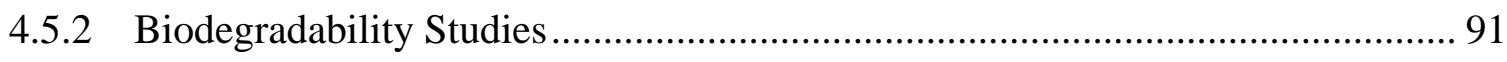

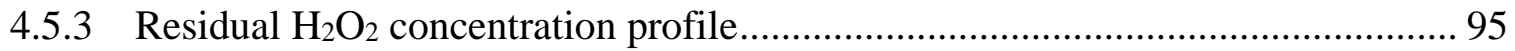

4.5.4 Determination of optimum $\mathrm{H}_{2} \mathrm{O}_{2}$ dosage and hydraulic retention time for combination of the $\mathrm{UV} / \mathrm{US} / \mathrm{H}_{2} \mathrm{O}_{2}$ and the aerobic AS processes ................................ 98

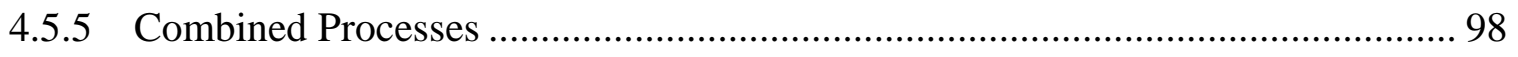

CHAPTER 5 CONCLUSIONS AND RECOMMENDATIONS ......................................... 102 


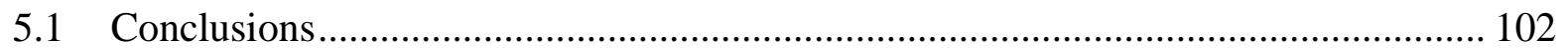

5.2 Recommendations .................................................................................... 105

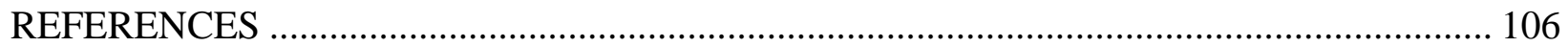

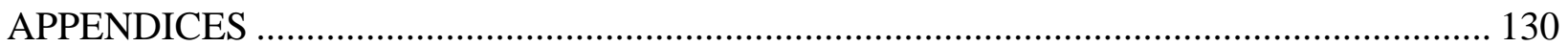

Appendix A. Determination of theoretical TOC and TN of the synthetic pharmaceutical

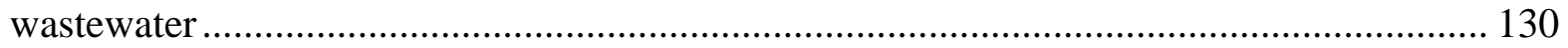

Appendix B. Calculation of Theoretical COD of the synthetic pharmaceutical wastewater 133

Appendix C. Determination of Reynolds number........................................................ 135

Appendix D. Determination of MLSS and MLVSS ................................................. 138

Appendix E. Determination of standard deviation and relative error ............................. 140 


\section{LIST OF TABLES}

Table 2.1. Characteristics of the wastewater from synthetic organic chemical plants and biological production plants (Murthy et al., 1984; Yeole et al., 1996)....................................... 7

Table 2.2. Most frequently detected pharmaceuticals in surface waters and their concentrations

(Adapted from Klavarioti et al., 2009). .................................................................................... 9

Table 2.3. Allowed COD values of the effluents for various types of pharmaceutical plants

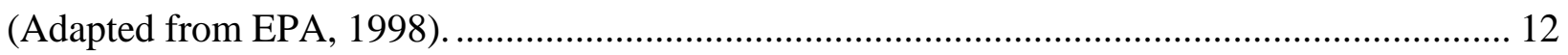

Table 2.4. Recommendations for wastewater discharges from federal facilities (Adapted from

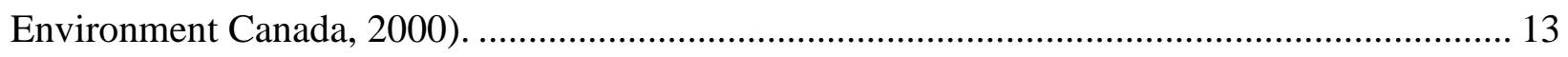

Table 2.5. Regulations for any new pharmaceutical industry plant (Adapted from EPA, 1998). 14

Table 2.6. Oxidizing potential of some oxidizing agents ................................................ 22

Table 2.7. Radicals produced in advanced oxidation processes (Adapted from Gulyas, 1997)... 24

Table 2.8. Synergic effect in the sonophotolysis processes................................................. 29

Table 2.9. Summary of research works which used combination of AOPs and biological methods for treatment of multicomponent pharmaceutical wastewater (AOP as post-treatment)............. 33

Table 2.10. Summary of research works which used combination of AOPs and biological methods for treatment of multicomponent pharmaceutical wastewater (AOP as pre-treatemt)... 35

Table 3.1.Concentration of pharmaceuticals in the raw wastewater ...................................... 37

Table 3.2. Composition of the SPWW used in this study .................................................. 38

Table 3.3. Physical properties of the chemicals in the SPWW ............................................ 39

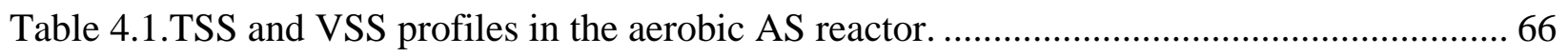




\section{LIST OF FIGURES}

Figure 3.1. Laboratory view of the experimental setup for the combined $\mathrm{UV} / \mathrm{US} / \mathrm{H}_{2} \mathrm{O}_{2}$ and

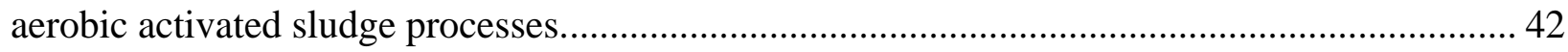

Figure 3.2. Schematic diagram of the experimental setup (sonophotoreactor and aerobic AS reactor) 43

Figure 3.3. Calibration curve of $\mathrm{H}_{2} \mathrm{O}_{2}$ concentration measurement based on DMP method....... 55

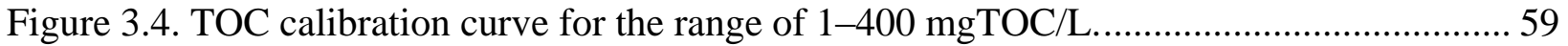

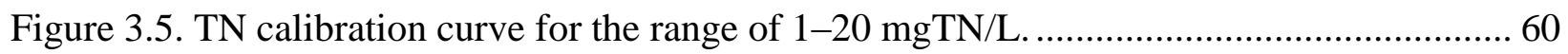

Figure 4.1. Evolution of MLSS and MLVSS for the aerobic AS process................................ 65

Figure 4.2. TOC reduction under batch mode $\mathrm{H}_{2} \mathrm{O}_{2}$, UV, US, UV/US, US/ $\mathrm{H}_{2} \mathrm{O}_{2}, \mathrm{UV} / \mathrm{H}_{2} \mathrm{O}_{2}$, and UV/US/ $\mathrm{H}_{2} \mathrm{O}_{2}$ processes $\left([T O C]_{\mathrm{o}}=89.67 \mathrm{mg} / \mathrm{L},\left[\mathrm{H}_{2} \mathrm{O}_{2}\right]_{\mathrm{o}}=1500 \mathrm{mg} / \mathrm{L}, \mathrm{US}\right.$ power $=100 \mathrm{~W}, \mathrm{pH}=$ 3.9 and airflow $=2 \mathrm{~L} / \mathrm{min})$ 70

Figure 4.3. Effect of initial $\mathrm{H}_{2} \mathrm{O}_{2}$ concentration on TOC removal efficiency during batch mode $\mathrm{UV} / \mathrm{US} / \mathrm{H}_{2} \mathrm{O}_{2}$ process $\left([\mathrm{TOC}]_{\mathrm{o}}=44.83 \mathrm{mg} / \mathrm{L}\right.$, US power $=140 \mathrm{~W}, \mathrm{pH}=3.9$ and airflow $\left.=2 \mathrm{~L} / \mathrm{min}\right)$.

Figure 4.4. Effect of initial $\mathrm{H}_{2} \mathrm{O}_{2}$ concentration on TOC removal efficiency during batch mode $\mathrm{UV} / \mathrm{US} / \mathrm{H}_{2} \mathrm{O}_{2}$ process $\left([\mathrm{TOC}]_{\mathrm{o}}=89.75 \mathrm{mg} / \mathrm{L}, \mathrm{US}\right.$ power $=140 \mathrm{~W}, \mathrm{pH}=3.9$ and airflow $\left.=2 \mathrm{~L} / \mathrm{min}\right)$.

Figure 4.5. Effect of initial $\mathrm{H}_{2} \mathrm{O}_{2}$ concentration on TOC removal efficiency during batch mode $\mathrm{UV} / \mathrm{US} / \mathrm{H}_{2} \mathrm{O}_{2}$ process $\left([\mathrm{TOC}]_{\mathrm{o}}=179.33 \mathrm{mg} / \mathrm{L}\right.$, US power $=140 \mathrm{~W}, \mathrm{pH}=3.9$ and airflow=2 L/min $)$.

Figure 4.6. Optimal initial concentration of $\mathrm{H}_{2} \mathrm{O}_{2}$ for $\mathrm{TOC}$ removal in different SPWW concentrations, after 90 treatment by $\mathrm{UV} / \mathrm{US} / \mathrm{H}_{2} \mathrm{O}_{2}$ process in batch mode. 76 
Figure 4.7. Relation of initial molar ratio of $\left[\mathrm{H}_{2} \mathrm{O}_{2}\right]_{\mathrm{o}} /[\mathrm{TOC}]_{\mathrm{o}}$ for different SPWW concentrations within the $\mathrm{UV} / \mathrm{US} / \mathrm{H}_{2} \mathrm{O}_{2}$ process in batch mode. 77

Figure 4.8. Effect of ultrasonic power on TOC removal efficiency during batch $\mathrm{US} / \mathrm{UV} / \mathrm{H}_{2} \mathrm{O}_{2}$ process $\left([\mathrm{TOC}]_{\mathrm{o}}=44.83 \mathrm{mg} / \mathrm{L},\left[\mathrm{H}_{2} \mathrm{O}_{2}\right]_{\mathrm{o}}=1750 \mathrm{mg} / \mathrm{L}, \mathrm{pH}=3.9\right.$, and air flow rate: $\left.2 \mathrm{~L} / \mathrm{min}\right) \ldots \ldots .79$ Figure 4.9. Effect of initial $\mathrm{pH}$ of the SPWW on TOC removal efficiency after 90 min batch mode US/UV/ $\mathrm{H}_{2} \mathrm{O}_{2}$ process $\left([\mathrm{TOC}]_{\mathrm{o}}=44.83 \mathrm{mg} / \mathrm{L},\left[\mathrm{H}_{2} \mathrm{O}_{2}\right]_{\mathrm{o}}=1750 \mathrm{mg} / \mathrm{L}, \mathrm{US}\right.$ Power $=140 \mathrm{~W}$ and air flow rate: $2 \mathrm{~L} / \mathrm{min})$. 82

Figure 4.10. Effect of air flow rate on TOC removal efficiency after 90 min batch mode $\mathrm{US} / \mathrm{UV} / \mathrm{H}_{2} \mathrm{O}_{2}$ process $\left([\mathrm{TOC}]_{\mathrm{o}}=44.83 \mathrm{mg} / \mathrm{L},\left[\mathrm{H}_{2} \mathrm{O}_{2}\right]_{\mathrm{o}}=1750 \mathrm{mg} / \mathrm{L}\right.$, US Power $=140 \mathrm{~W}$ and $\mathrm{pH}=2)$.

Figure 4.11. TOC removal for different SPWW concentrations at various HRT using aerobic activated sludge treatment in continuous mode without recirculation. 85

Figure 4.12. TN removal for different SPWW concentrations at various HRT using aerobic activated sludge treatment in continuous mode without recirculation. 86

Figure 4.13. COD removal for different SPWW concentrations at various HRT using aerobic activated sludge treatment in continuous mode without recirculation. 87

Figure 4.14. TOC removal using different $\mathrm{H}_{2} \mathrm{O}_{2}$ concentrations with inlet TOC concentration of $44.83 \mathrm{mg} / \mathrm{L}$ during continuous mode $\mathrm{UV} / \mathrm{US} / \mathrm{H}_{2} \mathrm{O}_{2}$. 90

Figure 4.15. BOD5/COD ratio of the pharmaceutical wastewater. 92

Figure 4.16. Evolution of average oxidation state during $\mathrm{UV} / \mathrm{US} / \mathrm{H}_{2} \mathrm{O}_{2}$ process at various $\mathrm{HRT}$, $[\mathrm{TOC}]_{\mathrm{in}}=44.83 \mathrm{mg} / \mathrm{L}$ 93

Figure 4.17. Evolution of $\mathrm{BOD}_{5} / \mathrm{COD}$ ratio during $\mathrm{UV} / \mathrm{US} / \mathrm{H}_{2} \mathrm{O}_{2}$ process at various $\mathrm{HRT}$, 94 
Figure 4.18. Residual $\mathrm{H}_{2} \mathrm{O}_{2}$ concentration in the effluent of the sonophotoreactor at various HRT,

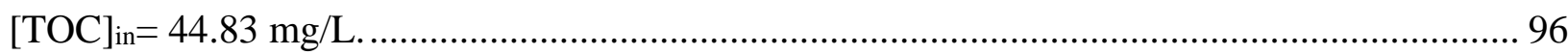

Figure 4.19. Comparison of TOC and COD removal using different alternatives in continuous mode without recycling, including $\mathrm{UV} / \mathrm{US} / \mathrm{H}_{2} \mathrm{O}_{2}$ process alone in continuous mode, aerobic AS process alone in continuous mode and combination of both processes $\left([\mathrm{TOC}]_{\text {in }}=44.83 \mathrm{mg} / \mathrm{L}\right.$, $[\mathrm{COD}]_{\mathrm{in}}=127 \mathrm{mg} / \mathrm{L}$, air flow rate in sonophotoreactor $=2 \mathrm{~L} / \mathrm{min}, \mathrm{pH}=2,\left[\mathrm{H}_{2} \mathrm{O}_{2}\right]_{\mathrm{in}}=750 \mathrm{mg} / \mathrm{L}$,

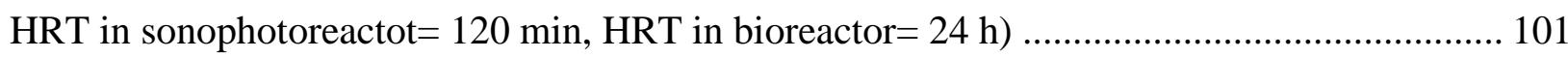




\section{NOMENCLATURE}

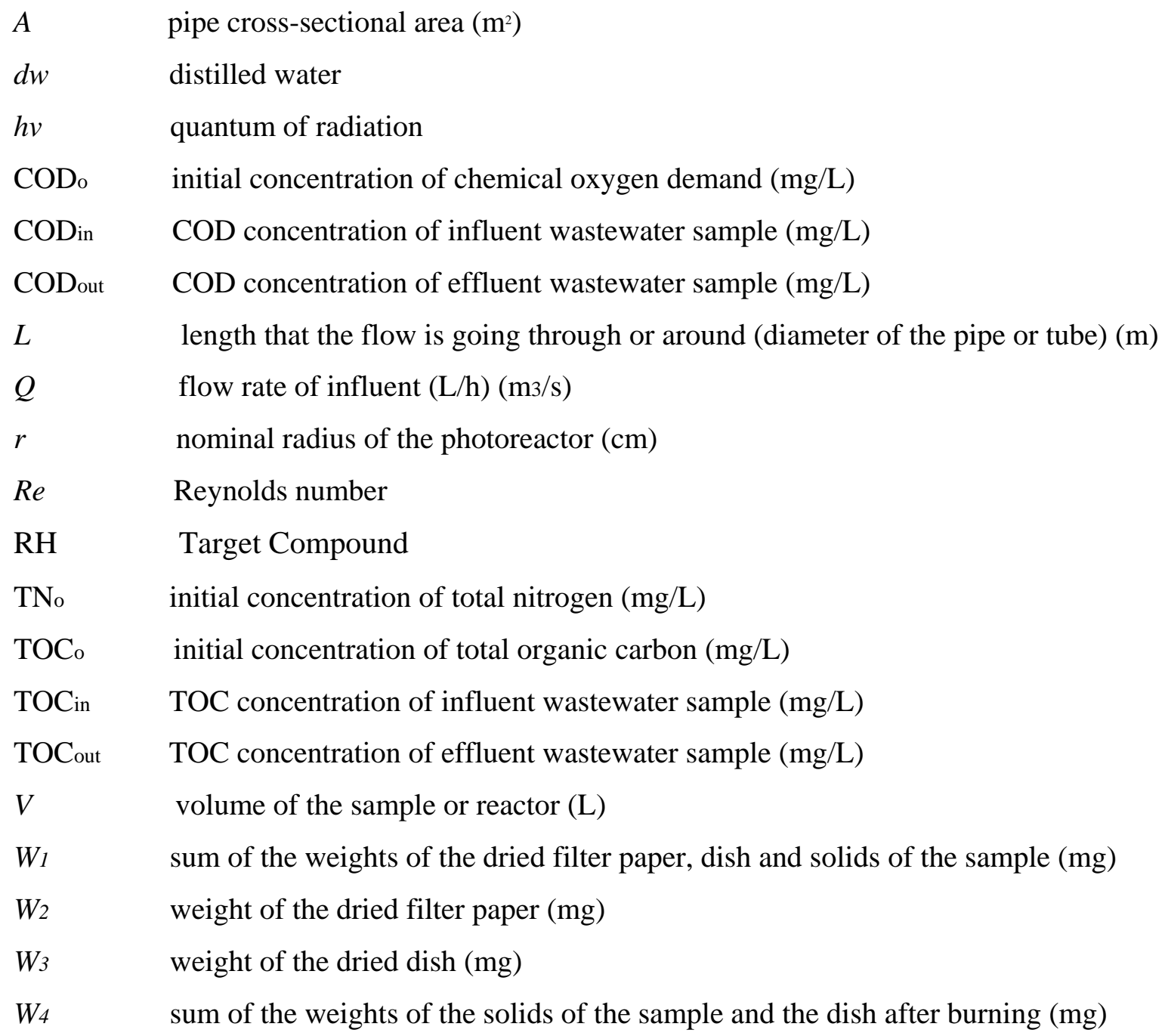

\section{Greek Letters}

$\mu \quad$ dynamic viscosity of the fluid (for water at $25^{\circ} \mathrm{C}, \mu=8.98 \times 10^{-4} \mathrm{~kg} / \mathrm{m} . \mathrm{s}$ )

$\rho \quad$ density of the fluid $\left(1000 \mathrm{~kg} / \mathrm{m}^{3}\right.$ for water at $\left.25^{\circ} \mathrm{C}\right)$

\section{Abbreviation}

$\mathrm{AO} 7$

AOP

$\mathrm{AC}$

AS

AOS

BAT
Acid Orange 7

Advanced Oxidation Process

Activated Carbon

Activated Sludge

Average Oxidation State

Best Available Technology 


\begin{tabular}{|c|c|}
\hline BCT & Best Control Technology \\
\hline BOD & Biochemical Oxygen Demand \\
\hline $\mathrm{BOD}_{5}$ & Biochemical Oxygen Demand in 5 days \\
\hline BPT & Best Practicable Control Technology \\
\hline CBOD & Carbonaceous Biochemical Oxygen Demand \\
\hline CWA & Clean Water Act \\
\hline COD & Chemical Oxygen Demand \\
\hline DMP & 2, 9-dimethyl-1, 10-phenathroline \\
\hline DO & Dissolved Oxygen \\
\hline EOP & Electrical Oxidation Potential \\
\hline EPA & Environmental Protection Agency \\
\hline GAC & Granular Activated Carbon \\
\hline HRT & Hydraulic Retention Time \\
\hline MBR & Membrane BioReactor \\
\hline MLSS & Mixed Liquor Suspended Solid \\
\hline MLVSS & Mixed Liquor Volatile Suspended Solid \\
\hline N/A & Not Available \\
\hline NSPS & New Source Performance Standards \\
\hline $\mathrm{NF}$ & Nano Filtration \\
\hline OLR & Organic Loading Rate \\
\hline PPCP & Pharmaceutical and Personal Care Products \\
\hline PAC & Powdered Activated Carbon \\
\hline $\mathrm{PhC}$ & Pharmaceutical Compounds \\
\hline RO & Reverse Osmosis \\
\hline SBR & Sequential Batch Reactor \\
\hline SPWW & Synthetic Pharmaceutical Wastewater \\
\hline SDWA & Safe Drinking Water Act \\
\hline $\mathrm{TN}$ & Total Nitrogen \\
\hline TOC & Total Organic Carbon \\
\hline TS & Total Solids \\
\hline TSS & Total Suspended Solid \\
\hline
\end{tabular}


VSS

UV

US

Volatile Suspended Solid

Ultraviolet

Ultrasound 


\section{CHAPTER 1 \\ INTRODUCTION}

At present, the occurrence of emerging contaminants such as pharmaceutical compounds, pesticides, oil and gasoline byproducts, etc. in water sources is a great environmental concern. Additionally, the population growth and the decline in available water resources make the reuse of industrial and municipal wastewater crucial. Furthermore, growing general knowledge about the negative impacts of exposure to polluted water causes progressively stricter regulations on the quality of discharged effluent especially in North America and Europe (Environment Canada, 2000; US EPA, 1998). This rising demand for high quality water has accelerated improvement of the conventional water treatment methods and led to creation of novel and effective treatment techniques. Due to varieties in living standards, available economic resources, locality and type of contaminates present in water bodies, diverse treatment methods have applied by nations to achieve clean and pure water.

Pharmaceutical components consist of a various group of human and veterinary medical compounds, which have long been used in great magnitudes throughout the world. Their application is to prevent and cure sicknesses and improve health condition. During last few decades, due to advances in medical science and population growth, production and consumption of pharmaceutical compounds increased significantly. Nowadays, several tons of medicines are manufactured each year for consumption of human and animals (Klavarioti et al., 2009).

Due to the nature of the manufacturing technologies involved in the production of pharmaceutical components, a huge amount of wastewater and process water is generated in the 
pharmaceutical industries (Laera et al., 2012). Pharmaceutical wastes are usually categorized as one of the main complex and toxic industrial waste with high biological oxygen demand (BOD), chemical oxygen demand (COD), total suspended solid (TSS), toxicity and odor as well as low $\mathrm{BOD} / \mathrm{COD}$ ratio. Moreover, wastewater from pharmaceutical industry might contain various amounts of organic solvents, catalysts, raw materials and reaction intermediates which makes their efficient treatment complicated (Gupta et al., 2004; Badawy et al., 2009; Schroder, 1999; Sreekanth et al., 2009).

Biological wastewater treatment is known as the most common and cost-effective method for treatment of almost all types of industrial wastewater (Kulik et al., 2008; Edalatmanesh et al., 2008; Chan et al., 2009). Mainly, biological methods are divided to two categories of aerobic and anaerobic treatment systems. In the case of industrial pharmaceutical wastewater, aerobic activated sludge (AS) with long hydraulic retention time (HRT) is the frequent treatment option (Oz et al., 2004). Membrane bioreactors (MBR) are other aerobic technologies which are used alone or in combination with AS to treat pharmaceutical wastewater (Chang et al., 2008; Mutamim et al., 2012). Based on the characteristics of wastewater, anaerobic methods such as anaerobic digestion (Enright et al., 2005) and anaerobic biofilters (Chen et al., 1994) are also applied in the treatment of pharmaceutical wastewater.

Even though conventional biological methods are economical choice of treatment, several types of industrial wastewater such as those from petrochemical, pharmaceutical, leather, dye, pulp and paper and pesticide manufacturing plants, contain considerable amount of organic compounds which are nonbiodegradable and refractory to microorganisms applied in biological treatment systems. These pollutants cannot be removed by conventional wastewater treatment plants and 
the standard regulations cannot be reached. Also, the release of these substances into the environment and their presence in drinking water may have harmful effects on both humans and ecosystems (Battimelli et al., 2010; Mannucci et al., 2010; Kraigher et al., 2008; Strenn et al., 2004). Considering the aforementioned issues, additional treatment steps seem to be indispensable.

Among technologies used to remove nonbiodegradable substances, it has been verified that advanced oxidation processes (AOPs) are influential treatment methods for degrading recalcitrant materials or mineralizing stable, inhibitory, or toxic contaminants (Legrini and Dickinson, 1993). AOPs such as ultraviolet (UV), UV/ $\mathrm{H}_{2} \mathrm{O}_{2}$, Fenton $\left(\mathrm{Fe}^{2+} / \mathrm{H}_{2} \mathrm{O}_{2}\right)$, sonolysis, etc. are of great interest and were used by several researchers to treat different types of pollutants during the past few decades (Ghafoori et al., 2013; Trovo et al., 2011; Sanches et al., 2010). They can be described as an oxidation method based on the intermediacy of highly reactive species such as hydroxyl radicals $\left({ }^{\circ} \mathrm{OH}\right)$ in a procedure leading to the degradation of the target contaminants (Comninellis et al., 2008). Even though AOPs are very effective in treating almost all organic compounds, some drawbacks prevent their commercial applications. The high requirement of oxidant/catalyst dosage, high electrical power consumption, and precise $\mathrm{pH}$ adjustment are some of these drawbacks which make operational cost of AOPs high (Klamerth et al., 2010). Therefore combination of AOPs and conventional biological treatments can be an ideal alternative to treat refractory pharmaceutical wastewater while reducing the consumption of oxidant dosage and hydraulic retention time in both systems. It should be noted that in conducting the experiments for combined processes, residual concentration of $\mathrm{H}_{2} \mathrm{O}_{2}$ in the effluent of the sonophotoreactor should be determined carefully since high concentrations of the oxidant could damage the biological system drastically. 


\section{OBJECTIVES}

The main goal of this research study was to investigate the efficiency of combined $\mathrm{UV} /$ ultrasound (US)/ $\mathrm{H}_{2} \mathrm{O}_{2}$ (sonophotolysis) and aerobic activated sludge processes for the treatment of high strength pharmaceutical wastewater. The details of the main objectives of this study are as follows:

1. To evaluate the performance of aerobic activated sludge and $\mathrm{UV} / \mathrm{US} / \mathrm{H}_{2} \mathrm{O}_{2}$ processes and their combination in reduction of TOC, TN, COD, and BOD from the synthetic pharmaceutical wastewater;

2. To determine optimal operation parameters such initial $\mathrm{H}_{2} \mathrm{O}_{2}$ concentration of the wastewater, initial $\mathrm{pH}$ of the wastewater, US output power and air flow rate in the sonophotoreactor for TOC removal in the effluent of the sonophotoreactor;

3. To evaluate the biodegradability enhancement of the pharmaceutical wastewater by the $\mathrm{UV} / \mathrm{US} / \mathrm{H}_{2} \mathrm{O}_{2}$ pretreatment;

4. To investigate evolution of $\mathrm{H}_{2} \mathrm{O}_{2}$ concentration in the effluent of the sonophotoreactor;

5. To determine the optimum hydraulic retention time in the AOP reactor as a pre-treatment for follow up treatment by aerobic activated sludge. 


\section{CHAPTER 2 \\ LITERATURE REVIEW}

\subsection{Introduction}

In this chapter, general information regarding pharmaceutical wastewater including main characteristics, environmental impacts and health effects, regulations and guidelines for its disposal is reviewed. Also, a comprehensive discussion on pharmaceutical wastewater treatment technologies, especially advanced oxidation process and biological treatment methods as well as the critical factors which are influential on their performance and a quick explanation of their mechanisms is provided. Finally, the necessity for application of advanced wastewater technologies (such as AOPs) to nonbiodegradable wastewater is stressed as well as the opportunities created by AOPs to serve as great auxiliary technologies to the conventional biological technologies, thus, boosting treatment efficiency and minimizing expenses.

\subsection{Characteristics of Pharmaceutical Wastewaters}

Pharmaceutical industries are characterized by a multiplicity of products, processes, plant sizes as well as by the magnitude and the quality of produced wastewater. For manufacturing each type of product, several processes and raw materials may be required; therefore, a significant quantity of waste streams with various pollution degrees and volumes are produced. These waste 
streams may vary even by season and plant. Gupta et al. (2004) divided pharmaceutical industries based on the process they applied in production into five main categories of fermentation plants, synthesized organic chemical plants, natural product extraction plants, drug mixing and preparation plants, and research and development units.

The main products of fermentation industries are antibiotics such as penicilines and tetracyclines. Several studies reported the very low ratio of 5-day biochemical oxygen demand to chemical oxygen demand (BOD5/COD ratio) and consequently the low biodegradability in the wastewater from antibiotic formulation process (Alaton et al., 2004; Xing and Sun, 2009).

Synthesis organic chemical plants are of great importance due to the wide range of pharmaceuticals produced. Generally, the organic and non organic raw materials are synthesized in these plants under proper operating condition to produce desired pharmaceutical compounds. The wastewater generated from these types of plants consists of a diversity of contaminants such as methylene chloride, chloroform, chlorobenzene, cyanide, phenol (EPA, 1997; Oktem et al., 2008). Additionally, the waste generated in these processes is tough, hard to treat, and in several cases nonbiodegradable (He and Bishop, 1994; Chen et al., 2008). Some researchers have divided the wastewater from these synthetic organic chemical plants into three groups of condensate waste, acid waste and alkaline waste (Murthy et al., 1984). Table 2.1 presents the characteristics of these three wastewater from synthetic organic chemical plants as well as wastes from biological production plants.

The third type of plants is called natural product extraction or biological production plants as shown in Table 2.1. Antitoxins, vaccines, serums, and toxoids are some products of these plants. Production of such substances results in waste stream which contains animal manure, animal organs, baby fluid, blood, fats, etc. Presence of such materials in the waste stream increases the 
amount of total solids significantly. High $\mathrm{BOD}_{5} / \mathrm{COD}$ ratio (more than 0.65 ) implies high biodegradability of this type of waste.

The two other types of plants are mostly involved in formulation and packaging. Research and development plants are involved in research based staffs for creation of new type of pharmaceuticals which could be more effective in cure of diseases.

Table 2.1. Characteristics of the wastewater from synthetic organic chemical plants and biological production plants (Murthy et al., 1984; Yeole et al., 1996).

\begin{tabular}{|c|c|c|c|c|c|c|}
\hline Industry & $\begin{array}{c}\text { Flow } \\
\text { Rate } \\
\left(m^{3} / \text { day }\right)\end{array}$ & pH & $\begin{array}{l}\text { Total Solids } \\
\quad(m g / L)\end{array}$ & $\begin{array}{c}\mathrm{BOD}_{5} \text { at } \\
20^{\circ} \mathrm{C} \\
(m g / L)\end{array}$ & $\begin{array}{c}\text { COD } \\
(m g / L)\end{array}$ & $\begin{array}{c}\text { Total alkalinity as } \\
\mathrm{CaCO}_{3} \\
(m g / L)\end{array}$ \\
\hline $\begin{array}{l}\text { Synthetic Alkaline } \\
\text { waste stream }\end{array}$ & 1,710 & $\begin{array}{l}2.3- \\
11.2\end{array}$ & $\begin{array}{l}11,825- \\
23,265\end{array}$ & $2,980-3,780$ & $5,480-7,465$ & $624-5630$ \\
\hline $\begin{array}{c}\text { Synthetic } \\
\text { Condensate waste } \\
\text { stream }\end{array}$ & $\begin{array}{l}1,570- \\
2,225\end{array}$ & $7-7.8$ & $2,742-4,150$ & $754-1,385$ & $1,604-2,500$ & $424-520$ \\
\hline $\begin{array}{l}\text { Synthetic Acid } \\
\text { waste stream }\end{array}$ & 435 & $\begin{array}{l}0.4- \\
0.65\end{array}$ & $\begin{array}{l}18,650- \\
23,880\end{array}$ & $2,920-3,260$ & $7,190-9,674$ & $\begin{array}{l}29,850-48,050 \\
\text { (acidity) }\end{array}$ \\
\hline $\begin{array}{c}\text { Biological } \\
\text { production plant } \\
\text { waste }\end{array}$ & N/A & $5-6.3$ & $\begin{array}{l}16,500- \\
21,600\end{array}$ & $\begin{array}{c}11,400- \\
16,100\end{array}$ & $\begin{array}{c}17,100- \\
24,200\end{array}$ & $3,800-4,350$ \\
\hline
\end{tabular}

\subsection{Occurrence and Fate of Pharmaceutical Wastes in Environment}

Based on therapeutic applications, pharmaceutical components (PhCs) are categorized in several classes including antibiotics, antiflammatory drugs, antiepileptics, beta-blockers, antidepressants, etc. The presence of these components $(\mathrm{PhCs})$ in surface water and ground water in the United 
States and Europe was detected for the first time in 1960s (Stumm-Zollinger and Fair, 1965). The PhCs range from non-prescribed and prescribed drugs, antibacterial agents, and surfactants that are regularly found in domestic and household products. In recent years persistent improvements in analytical technology allow the determination of even very low concentration levels of contaminates in diverse water matrices. Generally, PhCs can be found in quantities of $\mathrm{ng} / \mathrm{L}$ to low $\mathrm{mg} / \mathrm{L}$ in many aquatic compartments such as wastewaters treatment plants, surface water, ground water and drinking water (Bianca Ferreria da Silva et al., 2011; Huerta-Fontela et al., 2011). Table 2.2 indicates the pharmaceutical compounds which were detected most frequently in wastewater and their concentration.

Most of the PhCs go through transformations in the human and animal bodies. This transformation brings considerable amounts of diversity of metabolites into the aquatic environment (Nikolaou et al., 2007). Municipal and hospital wastewaters are the major sources of environmental pollution by human pharmaceuticals. On the other hand, employment of PhCs to fields and following runoff, and direct application in aquaculture have significant effects in contamination through veterinary pharmaceuticals. Numerous pathways are reported for environmental pollution via PhCs. 
Table 2.2. Most frequently detected pharmaceuticals in surface waters and their concentrations (Adapted from Klavarioti et al., 2009).

\begin{tabular}{|c|c|}
\hline Component Group & Type, name and concentration of the component \\
\hline Antibiotics & $\begin{array}{l}\text { sulfonamides: sulfamethoxazole }(0.02-0.58(\mu \mathrm{g} / \mathrm{L}) \\
\text { fuoroquinolones: ofloxacin }(6-52 \mathrm{ng} / \mathrm{L}) \text {, ciprofloxacin }(6-60 \mathrm{ng} / \mathrm{L}) \\
\text { bacteriostatic: trimethoprim }(0.11-0.37 \mu \mathrm{g} / \mathrm{L}) \\
\text { penicillin group: penicillin } \mathrm{G}(<0.025 \mu \mathrm{g} / \mathrm{L})\end{array}$ \\
\hline Analgesics/Antipyretics & $\begin{array}{l}\text { acetaminophen }(10-23.33 \mu \mathrm{g} / \mathrm{L}) \text {, diclofenac }(0.01-510 \mu \mathrm{g} / \mathrm{L}) \text {, naproxen } \\
(0.5-7.84 \mu \mathrm{g} / \mathrm{L}) \text {, ibuprofen }(0.49-990 \mu \mathrm{g} / \mathrm{L}) \text {, ketoprofen }(0.13-3 \mu \mathrm{g} / \mathrm{L}) \\
\text { carbamazepine }(0.1-1.68 \mu \mathrm{g} / \mathrm{L})\end{array}$ \\
\hline $\begin{array}{l}\text { CNS (central nervous } \\
\text { system) drugs }\end{array}$ & caffeine $(3.2-11.44 \mu \mathrm{g} / \mathrm{L})$ \\
\hline Cardiovascular Drugs & $\begin{array}{l}\text { propranolol }(0.05 \mu \mathrm{g} / \mathrm{L}) \text {, atenolol }(10-730 \mathrm{ng} / \mathrm{L}) \text {, metoprolol (10-390 } \\
\text { ng/L), clofibric acid }(0.47-170 \mu \mathrm{g} / \mathrm{L}) \text {, gemfibrozil }(0.3-3 \mu \mathrm{g} / \mathrm{L}) \text {, fezafibrate } \\
(0.1-7.60 \mu \mathrm{g} / \mathrm{L})\end{array}$ \\
\hline Endocrinology Treatment & $\begin{array}{l}\text { 17 } \alpha \text {-ethinylestradiol }(1 \mathrm{ng} / \mathrm{L}) \text {, estrone, } 17 \beta \text {-estradiol, estriol (usually less } \\
\text { than } 10 \mathrm{ng} / \mathrm{L} \text { ) }\end{array}$ \\
\hline $\begin{array}{l}\text { Diagnostic Aid-Absorbable } \\
\text { Organic Halogen } \\
\text { Compounds }\end{array}$ & iopromide $(0.026-7.5 \mu \mathrm{g} / \mathrm{L})$, iomeprol $(1.6 \mu \mathrm{g} / \mathrm{L})$ \\
\hline
\end{tabular}

The exertion of unchanged components by urine and faeces, metabolism after intake, domestic disposal and diagnostic compounds are some of these pathways (Lucia Santos et al., 2010). PhCs which enter the aquatic environment cannot be removed completely due to inability of conventional wastewater treatment plants. Therefore, PhCs can also contaminate surface water. Several researchers reported the presence of toxic pharmaceutical compounds in surface water (Sacher et al., 2008; Kasprzyk-Hordern et al., 2008). Due to their continuous presence in ground and surface water resources, they have attracted augmented attention in the past few years, and their elimination from environment has been studied by several researchers. 


\subsection{Environmental Effects of Pharmaceutical Contaminants}

Contamination through pharmaceuticals can occur in various concentration ranges from ng/L to $\mathrm{mg} / \mathrm{L}$. Although, these concentrations are very small, they have a high potential to cause environmental effects (Jones et al., 2004).

Any stage of the biological hierarchy such as cells, organs, organisms, ecosystems, etc. could be damaged by the imposed toxicity from pharmaceuticals that enter the environment. Additionally, some specific groups of $\mathrm{PhCs}$ could make permanent changes on the structure of microorganisms (Klavarioti et al., 2009). For examples, the development of antibiotic-resistant bacteria is a growing concern (Brown et al., 2006). Several studies report that antibiotics can cause resistance in natural bacterial population even at low concentrations (Akiyama and Savin, 2010; Nikolaou et al., 2007). Another example is regarding a group of PhCs named endocrine disrupting compounds (EDCs). The presence of EDCs is known to damage and disrupt the endocrine system in human bodies as well as harmful health impacts in aquatic organism (; Sonnenschein and Soto, 1998; Sumpter, 1998; Bredhult et al., 2007).

Considerations and concerns regarding the presence of $\mathrm{PhCs}$ in the environment enhance research activities in the field of pharmaceutical wastewater treatment. Developing new techniques such as advanced oxidation processes and improving treatment ability of conventional treatment methods such as biological methods and adsorption on solids are the outcomes of these research activities (Reungoat et al., 2012; Wei et al., 2012; Kohler et al., 2012).

The presence of PhCs can be a major contamination source of soil. Aga et al. (2008) mentioned that pharmaceuticals can end up in the water matrices through effluents from wastewater treatment plants and in soils when sewage sludge produced during wastewater treatment is used 
as fertilizer. Additionally, the formation of resistant microorganisms in soil is reported by Thielebruhn (2003).

The presence of pharmaceutical compounds is a severe environmental trouble due to the fact that these substances are nonbiodegradable and are refractory to microorganisms employed in conventional biological treatments. So they could escape unaltered from treatment plans. Consequently, their release into the environment may cause damage to humans and other organisms. Therefore, effective treatment methods are required to remove these pollutants and minimize their concentration in the environment.

\subsection{Regulations and Discharge Parameters of Pharmaceutical Wastewater Effluents}

There is a certain level of contaminants that are allowed to exist in discharges water streams of industrial and municipal plants. In order to keep the quality of these discharge streams, governmental organizations establish certain guidelines and regulations that every industry has to obey.

Due to growing awareness of harmful effects of exposure to contaminated water, the required degree of treatment has been enhanced notably during time. This means that in each new regulation, extra goals have been added to achieve higher removal rate of pollutants from water and to improve general health conditions.

The U.S. Environmental Protection Agency (EPA) regulates pollutants such as pharmaceutical compounds in wastewater and drinking water through the Clean Water Act (CWA) and the Safe 
Drinking Water Act (SDWA). A complete list of regulation and limitations on the final discharge for pharmaceutical production plants can be seen in the EPA guideline (EPA, 1998).

These guidelines and regulations establish discharge limitation standards under the CWA including Best Practicable Control Technology currently available (BPT), Best Conventional Pollutant Control Technology (BCT), Best Available Technology Economically Achievable for Existing Direct Dischargers (BAT), New Source Performance Standards for New Direct Dischargers (NSPS), and Pre-treatment Standards for Existing and New Indirect Dischargers (PSES and PSNS).

Table 2.3, for example, presents COD discharge limits for various categories of pharmaceutical plants.

Table 2.3. Allowed COD values of the effluents for various types of pharmaceutical plants (Adapted from EPA, 1998).

\begin{tabular}{lll}
\hline Plant category & $\begin{array}{l}\text { Maximum for one day } \\
(\mathbf{m g} / \mathbf{L})\end{array}$ & $\begin{array}{l}\text { Monthly average } \\
(\mathbf{m g} / \mathbf{L})\end{array}$ \\
\hline $\begin{array}{l}\text { Fermentation Plants } \\
\text { Biological and natural } \\
\text { extraction plants }\end{array}$ & 228 & 856 \\
$\begin{array}{l}\text { Chemical synthesis } \\
\text { plants }\end{array}$ & 1675 & 86 \\
$\begin{array}{l}\text { Mixing and formulation } \\
\text { plants }\end{array}$ & 228 & 856 \\
\hline
\end{tabular}


Table 2.4. Recommendations for wastewater discharges from federal facilities (Adapted from Environment Canada, 2000).

\begin{tabular}{|c|c|c|}
\hline Parameter & Wastewater Disposal Pathway & $\begin{array}{l}\text { Effluent Discharge } \\
\text { Recommendation } \\
\text { (unless otherwise } \\
\text { specified) }(\mathrm{mg} / \mathrm{L})\end{array}$ \\
\hline \multirow[t]{3}{*}{ BOD5 } & $\begin{array}{l}\text { Freshwater, lakes, } \\
\text { slow flowing stream }\end{array}$ & 5 \\
\hline & River, streams and estuaries & 20 \\
\hline & Shoreline & 30 \\
\hline Fecal coliforms & & $100 / 100 m L$ \\
\hline Total coliforms count & & $1,000 / 100 m L$ \\
\hline \multirow[t]{3}{*}{ Total suspended solids (TSS) } & $\begin{array}{l}\text { Freshwater, lakes, } \\
\text { slow flowing stream }\end{array}$ & 5 \\
\hline & River, streams and estuaries & 20 \\
\hline & Shoreline & 30 \\
\hline Reactive chlorine & & $\begin{array}{l}0.01 \text { or current } \\
\text { detection limit }\end{array}$ \\
\hline $\mathrm{pH}$ & & $6-9$ \\
\hline Phenol (mono and dihydric) & & 0.02 \\
\hline Oils and grease & & 5 \\
\hline Ammonia $\left(\mathrm{NH}_{3}\right)$ & & 1 \\
\hline Nitrates $\left(\mathrm{NO}_{3}, \mathrm{NO}_{2}\right.$ in form of $\left.\mathrm{N}\right)$ & & 10 \\
\hline Phosphorous (P) & & 1 \\
\hline Sulphur (S) & & 0.5 \\
\hline Temperature & \multicolumn{2}{|c|}{ ambient temperature should not change more than $1^{\circ} \mathrm{C}$} \\
\hline
\end{tabular}


Table 2.5. Regulations for any new pharmaceutical industry plant (Adapted from EPA, 1998).

\begin{tabular}{|c|c|c|}
\hline \multirow[t]{2}{*}{ Pollutant parameter } & \multicolumn{2}{|c|}{ Discharge Limitations (mg/L) } \\
\hline & Maximum Daily Discharge & $\begin{array}{c}\text { Average Discharge per } \\
\text { Month }\end{array}$ \\
\hline $\mathrm{BOD}_{5}$ & 267 & 111 \\
\hline TOC & 320 & 216 \\
\hline COD & 1675 & 856 \\
\hline Ammonia (as N) & 84.1 & 29.4 \\
\hline Acetone & 0.5 & 0.2 \\
\hline $\begin{array}{l}\text { 4-Methyl-2-pentanone } \\
\text { (MIBK) }\end{array}$ & 0.5 & 0.2 \\
\hline Isobutyraldehyde & 1.2 & 0.5 \\
\hline n-Amyl acetate & 1.3 & 0.5 \\
\hline n-Butyl acetate & 1.3 & 0.5 \\
\hline Ethyl acetate & 1.3 & 0.5 \\
\hline Isopropyl acetate & 1.3 & 0.5 \\
\hline Methyl formate & 1.3 & 0.5 \\
\hline Amyl alcohol & 10.0 & 4.1 \\
\hline Ethanol & 10.0 & 4.1 \\
\hline Isopropanol & 3.9 & 1.6 \\
\hline Methanol & 10.0 & 4.1 \\
\hline Methyl Cellosolve & 25.0 & 10.2 \\
\hline Dimethyl Sulfoxide & 91.5 & 37.5 \\
\hline Triethyl Amine & 250.0 & 102.0 \\
\hline Phenol & 0.05 & 0.02 \\
\hline Benzene & 0.05 & 0.02 \\
\hline Toluene & 0.06 & 0.02 \\
\hline Xylenes & 0.03 & 0.01 \\
\hline n-Hexane & 0.03 & 0.02 \\
\hline n-Heptane & 0.05 & 0.02 \\
\hline Methylene chloride & 0.9 & 0.3 \\
\hline Chloroform & 0.02 & 0.01 \\
\hline 1,2-Dichloroethane & 0.4 & 0.1 \\
\hline Chlorobenzene & 0.15 & 0.06 \\
\hline o-Dichlorobenzene & 0.15 & 0.06 \\
\hline Tetrahydrofuran & 8.4 & 2.6 \\
\hline Isopropyl ether & 8.4 & 2.6 \\
\hline Diethyl amine & 250.0 & 102.0 \\
\hline Acetonitrile & 25.0 & 10.2 \\
\hline Cyanide & 33.5 & 9.4 \\
\hline
\end{tabular}


Also, Table 2.4 represents the standard regulations recommended for discharge quality by federal institutions in Canada (Environment Canada, 2000). Furthermore, any new plant subject to the pharmaceutical industry and its various sections must meet the standard regulations mentioned in Table 2.5 (EPA, 1998).

\subsection{Pharmaceutical Wastewater Treatment Technologies}

Due to various characteristics of pharmaceutical wastes, there is no certain treatment method that is capable of removing all types of these components with high efficiency (Verlicchi et al., 2010). Additionally, the diversity in properties of the effluents from pharmaceutical industries (Table 2.1.) results in the employment of a wide range of treatment methods. As mentioned in section 2.2, the discharge from pharmaceutical plants may vary even with time, season, and location. Some researchers reported various treatment efficacies from cold seasons to hot seasons (Miège et al., 2008; Choi et al., 2008). Verlicchi et al. (2010) divided technologies in the treatment of pharmaceutical wastewaters into six main groups as follows:

- Physico-chemical treatments

- Reverse osmosis

- Nanofiltration

- Disinfection

- Conventional biological treatment

- Advanced oxidation processes 


\subsubsection{Physico-chemical treatments}

Main physico-chemical methods used in the open literature for the treatment of pharmaceutical wastewater are coagulation-flocculation and adsorption through activated carbon (AC). Suarez et al. (2009) applied coagulation-flocculation as pre-treatment for hospital wastewater. The treatment was able to reduce TSS by about $92 \%$ and COD up to $70 \%$, however, the removal of most of the PhCs such as antibiotics were marginal. Another study by Ternes and Jones (2006) also showed the failure of the coagulation-flocculation process in the elimination of pharmaceutical and personal care products (PPCPs) from water solutions.

Adsorption of micropollutants through activated carbon in both powdered (PAC) and granular forms (GAC) was studied by several researchers. More than $90 \%$ removal of estrogens was reported by both GAC and PAC processes (Snyder et al., 2007). Also, up to $90 \%$ removal of endocrine disrupting material by PAC was observed by Schafer et al. (2003). Although activated carbon has a great ability to adsorb many pharmaceutical components, some problems are associated with their application in wastewater treatment. Transfer of pollutants form one phase to another, complications of separating PAC from water and relatively high treatment cost are some of these problems (Oller et al., 2011; Deegan et al., 2011).

\subsubsection{Reverse Osmosis and nanofiltration}

Reverse osmosis (RO) and nanofiltration (NF) are frequently employed for tertiary step in wastewater and drinking water treatment (Nghiem et al., 2005; Watkinson et al., 2007).

Several studies confirmed the efficient removal of many PPCPs through RO process. Oppenheimer et al. (2007) stated that RO removed all the detected pharmaceutical compounds, 
even those which were not eliminated considerably by biological process. Aniline was also reported to be removed by more than $91 \%$ during treatment by RO (Gomez et al., 2009). Watkinson et al. (2007) studied removal of 28 antibiotics in a wastewater treatment plant in Australia with an average removal of $92 \%$. Despite these great results, some PPCPs had limited removal while treatment via RO process. Braghetta and Brownawell (2002) observed only $60 \%$ and 64\% removal for diclofenac and ketoprofen, respectively. Also, Snyder et al. (2007) reported unsatisfactory elimination of compounds such as pentoxifylline, iodopromide, meprobamate, phosphanetriyl, and gemfibrozil during RO treatment. In case of the NF process, some studies reported more than 90\% removal of PPCPs (Bolong et al., 2009; Yoon et al., 2006). Discarding the sludge from both RO and NF processes which has high concentration of the pollutants is a major problem associated with these processes (Deegan et al., 2011).

\subsubsection{Disinfection}

Disinfection is an important process in treatment of drinking water (Kosma et al., 2010). For pharmaceutical wastewater, disinfection has been done by several compounds such as chlorine, chlorine oxide, and sodium hypochlorite.

Chlorine is the most frequent disinfectant that is used to control pathogens in drinking water (Lee and von Gunten, 2010). Acero et al. (2010) studied degradation rate of some PPCPs during chlorination. They mentioned that $\mathrm{pH}$ has a significant effect on degradation rate. Naproxen, amoxicillin, and phenacetin in $\mathrm{pH}$ range of $2-4$ had great degradation rate, while their degradation in $\mathrm{pH}$ range of 5-9 was decreased. Chlorination was also successful in removal of fluoroquinolones, sulfonamides, $\beta$-lactumsand, macrolides, 17 $\alpha$-ethinylestradiol, and $17 \beta$ estradiol (Sharma et al., 2008; Qiang et al., 2006; Alum et al., 2004). 
Nardi et al. (1995) observed high removal rate of bacteria and viruses in the effluent from an infectious diseases region through disinfection by $\mathrm{ClO}_{2}$. Components such as sulfamethoxazole, roxithromycin, 17a-ethinylestradiol and diclofenac were also eliminated from aqueous solutions by addition of $\mathrm{ClO}_{2}$ (Khetan and Collins, 2007). In case of $\mathrm{NaClO}$, Emmanuel (2004), observed significant reduction of bacteria pollution.

\subsubsection{Biological wastewater treatment}

Biological wastewater treatment is the use of bacteria and other microorganisms for reducing the pollution level of wastewater. The overall goals of the treatment are to reduce the suspended solid level of the wastewater, eliminate or convert nutrients, incorporate non settleable colloidal solids into biological flocs and above all, transform biodegradable contaminants to satisfactory and less toxic end products.

In case of pharmaceutical wastewater, biological techniques have been used traditionally. Relatively low capital cost and the ability to treat wide range of contaminants are the main advantages of biological treatment methods. Broadly, they are divided into two main categories of aerobic and anaerobic techniques. Characteristics of the wastewater are the main parameter in selecting the type of biological treatment. During anaerobic treatments, the organic pollutants are degraded to methane by microorgansims. The process is performed in the absence of oxygen. Anaerobic reactions take place in 4 types of reactors including anaerobic filters, anaerobic sludge reactors, fluidized bed reactors, and anaerobic film reactors. Aerobic biological treatments, on the other hand, degrade organic compounds in presence of oxygen; however, the end products do not contain methane. 
Both aerobic and anaerobic methods have advantages and disadvantages. Anaerobic systems have higher efficiency for treatment of high strength wastewater. Lower sludge production, lower energy requirement and operating cost are other advantages of anaerobic systems while comparing to aerobic ones (Deegan et al., 2011). Also, the methane which is produced during the treatment could be applied as a source of energy. Advantages of aerobic systems include higher ability of elimination of soluble biodegradable organic matters and lower suspended solid concentration in the effluent (Grady et al., 1999).

Several studies could be found in literature regarding anaerobic treatment of pharmaceutical wastewater (Velvizhi and Venkata Mohan, 2011; Ji et al., 2013). Sreekanth et al. (2009) studied the efficiency of an anaerobic sludge blank reactor for reducing BOD and COD of high organic load pharmaceutical wastewater. Up to $75 \%$ COD and 95\% BOD reduction was achieved. Also, around $70 \%$ of the generated biogas was methane. In another study, Oktem et al. (2008) reported the treatment of a pharmaceutical wastewater with COD range of 40,000 to $60,000 \mathrm{mg} / \mathrm{L}$ with anaerobic sludge blanket reactor. They observed various COD removals while changing the organic loading rate (OLR) of the influent of the anaerobic reactor. COD removal was around $90 \%$ to $28 \%$ for different inlet COD values.

Main aerobic systems are activated sludge (AS), membrane bioreactors (MBR), and sequencing batch reactor (SBR). Aerobic activated sludge system, which is used in this study as well, is the most common method that has been used for treatment of pharmaceutical wastewater (El Gohary and Abou-Elea, 1995). Important factors which should be considered while using activated sludge systems are hydraulic retention time (HRT), dissolved oxygen, temperature, $\mathrm{pH}$, and the bacterial community (Painter and Loveless, 1983; LaPara et al., 2001; Bernhard et al., 2006; Vieno et al., 2007). Also, it should be considered that many waste streams of pharmaceutical 
industries consist of recalcitrant and nonbiodegradable components which could not be degraded effectively in biological systems. Verlichi et al., (2012) reviewed removal efficiency of activated sludge systems on elimination of $118 \mathrm{PhCs}$ in urban wastewater treatment plants. The study showed high efficiency of AS process in removal of PhCs. However, in many cases unsatisfactory removals were observed. Analgesics such as mefenamic acid, naproxen and diclofenac, antibiotics such as enrofloxin and sulfamethazine, and lipid regulators such as carbamazepine are some examples of the components which were not removed suitably. Another review work on biodegradation of PPCPs were done by Onesios et al. (2009). SBR and MBR were shown to be effective methods as well. Ileri et al. (2003) reported 82\% BOD, 88\% COD, and 98\% TSS removal from a pharmaceutical wastewater using SBR. Other studies regarding aerobic methods could be found in the open literature (Kimuera et al., 2007; Gobel et al., 2005).

\subsubsection{Advanced oxidation processes (AOPs)}

Advanced oxidation processes are relatively new and effective technologies which have gained a lot of attention in the field of water and wastewater treatment in the past 30 years. AOPs are oxidation methods which degrade a wide range of pollutants by in situ formation of highly reactive radicals such as hydroxyl radical ( $\left.{ }^{\circ} \mathrm{OH}\right)$ (Gogate and Pandit, 2004). These radical can rapidly and non-selectively mineralize even refractory and recalcitrant organic components in water. The major advantage of AOPs is their capability to destroy the organic pollutants completely without transferring them to another phase or producing secondary waste disposal troubles. The term "Advanced" is given to these processes due to the fast reaction (in terms of seconds) of the organic matters with hydroxyl radicals (Bolton and Cotton, 2008). AOPs consist of four main groups; 
- Photochemical processes such as $\mathrm{UV} / \mathrm{H}_{2} \mathrm{O}_{2}, \mathrm{UV} / \mathrm{O}_{3}$, and $\mathrm{UV} / \mathrm{O}_{3} / \mathrm{H}_{2} \mathrm{O}_{2}$, in which radiation of the UV light plays a secondary role by initiating the photoreaction in the presence of an auxiliary oxidant like $\mathrm{O}_{3}$ or $\mathrm{H}_{2} \mathrm{O}_{2}$ to produce ${ }^{\circ} \mathrm{OH}$ radicals;

- Photocataytic processes such as photo-Fenton and $\mathrm{UV} / \mathrm{TiO}_{2}$ in which a catalyst plays a secondary role by absorbing $\mathrm{UV}$ radiation to produce ${ }^{\circ} \mathrm{OH}$ radicals;

- Chemical oxidation such as ozonation $\left(\mathrm{O}_{3}\right), \mathrm{O}_{3} / \mathrm{H}_{2} \mathrm{O}_{2}$ and $\mathrm{H}_{2} \mathrm{O}_{2} / \mathrm{Fe}^{2+}$ among others (Tchobanoglous et al., 2003; Oppenländer, 2003);

- Sonolytic processes in which ultrasound (US) is applied to destroy organic pollutants.

Recently some researches combine UV and US lights to improve the treatment efficiency. This leads to the creation of another group named sonophotolysis which in presence of catalyst is called sonophotocatalysis (Shirgaonkar and Pandit, 1998; Madhavan et al., 2010).

Redox reactions which are the exchange of electron between chemicals are the basic principle of chemical oxidations like advanced oxidation processes. In redox reactions, the compounds that gain electrons are known as oxidizing agents, while compounds losing electrons are known as reducing agents. Radicals which are produced during AOPs, especially, ${ }^{\circ} \mathrm{OH}$, are powerful oxidizing agents. McMurray and Fay (2011) mentioned that the exchange of electrons between an oxidant and a reductant is conduced by the difference in their electrical oxidation potentials (EOP). Table 2.6 demonstrates the EOP of some strong oxidizing agents. 
Table 2.6. Oxidizing potential of some oxidizing agents

(Adapted from Tarr, 2003).

\begin{tabular}{c|c}
\hline Oxidizing agent & EOP (Volt) \\
\hline Fluorine & 3.06 \\
Hydroxyl radical & $\mathbf{2 . 8 0}$ \\
Oxygen (atomic) & 2.42 \\
Ozone & 2.08 \\
Hydrogen peroxide & 1.78 \\
Hypochlorite & 1.49 \\
Chlorine(molecular) & 1.36 \\
Chlorine oxide & 1.27 \\
Oxygen (molecular) & 1.23 \\
\hline
\end{tabular}

As Table 2.6 shows, hydroxyl radicals have the highest EOP (2.80V) among all the typical chemical oxidizing agents that are used in water and wastewater treatment processes. Chlroine, for example, which is used in disinfection process, has an oxidizing potential two times lower than that of hydroxyl radical. Therefore, ${ }^{\circ} \mathrm{OH}$ is the most powerful accessible oxidant in the field of water treatment for breakage of carbon bonds, transforming parent target compounds into either a less toxic and less refractory intermediates or into water and carbon dioxide as the final products of mineralization.

There are four main possible pathways for the reaction between hydroxyl radicals and organic matters as follows; (Barrera, 2011; Bolton, 2010; Asano et al., 2007; Braun and Oliveros, 1997; Legrini and Dickinson, 1993). 
- Radical addition; the radical addition could be explained as the addition of ${ }^{\circ} \mathrm{OH}$ to an unsaturated aliphatic or aromatic organic compound $(\mathrm{R})$, such as $\mathrm{CH}=\mathrm{CCl}_{2}$ which results in the generation of radical organic compounds; for example:

$$
\mathrm{CHCL}=\mathrm{CCL}_{2}+{ }^{\bullet} \mathrm{OH} \rightarrow{ }^{\bullet} \mathrm{CHCl}-\mathrm{C}(\mathrm{OH}) \mathrm{Cl}_{2}
$$

- Hydrogen abstraction; in the mechanism of hydrogen abstraction, radical organic compounds are produced by the removal of a hydrogen atom typically from the aliphatic hydrocarbons group such as methanol $\left(\mathrm{CH}_{3} \mathrm{OH}\right)$ under the reaction with ${ }^{\circ} \mathrm{OH}$; for example:

$$
\mathrm{CH}_{3} \mathrm{OH}+{ }^{\bullet} \mathrm{OH} \rightarrow{ }^{\bullet} \mathrm{CH}_{2} \mathrm{OH}+\mathrm{H}_{2} \mathrm{O}
$$

- Electron transfer; Ions of higher valence are formed due to electron transfer, in which a monovalent negative ion forms either an atom or a free radical; for example:

$$
\mathrm{I}^{-}+{ }^{\bullet} \mathrm{OH} \rightarrow \mathrm{I}^{\bullet}+\mathrm{OH}^{-}
$$

- Radical combination; two radicals may also combine to form a stable product; for example:

$$
\cdot \mathrm{OH}+{ }^{\bullet} \mathrm{OH} \rightarrow \mathrm{H}_{2} \mathrm{O}_{2}
$$

Other than hydroxyl radicals, other radicals are also generated by various AOPs. Table 2.7 lists these radicals generated in AOPs. 
Table 2.7. Radicals produced in advanced oxidation processes (Adapted from Gulyas, 1997).

\begin{tabular}{|c|c|}
\hline Free radical & Process \\
\hline${ }^{\circ} \mathrm{OH}$ & $\begin{array}{l}\mathrm{UV} / \mathrm{H}_{2} \mathrm{O}_{2}, \mathrm{UV} / \mathrm{O}_{3}, \mathrm{UV} / \mathrm{O}_{3} / \mathrm{H}_{2} \mathrm{O}_{2}, \mathrm{O}_{3}, \mathrm{O}_{3} / \\
\mathrm{H}_{2} \mathrm{O}_{2}, \mathrm{H}_{2} \mathrm{O}_{2} / \mathrm{Fe}^{2+} \text { (Fenton process), } \mathrm{H}_{2} \mathrm{O}_{2} / \mathrm{Fe}^{2+} \\
\text { (photo Fenton), } \mathrm{TiO}_{2} / \mathrm{UV} \text { (photocatalysis), } \\
\mathrm{TiO}_{2} / \mathrm{UV} / \mathrm{H}_{2} \mathrm{O}_{2} \text {, Sonolysis, Sonophotolysis }\end{array}$ \\
\hline $\mathrm{HO}_{2}{ }^{\circ}$ & $\begin{array}{l}\mathrm{UV} / \mathrm{H}_{2} \mathrm{O}_{2}, \mathrm{UV} / \mathrm{O}_{3}, \mathrm{UV} / \mathrm{O}_{3} / \mathrm{H}_{2} \mathrm{O}_{2}, \mathrm{O}_{3}, \mathrm{O}_{3} / \\
\mathrm{H}_{2} \mathrm{O}_{2}\end{array}$ \\
\hline $\mathrm{HO}_{3}{ }^{\circ}$ & $\mathrm{UV} / \mathrm{O}_{3}, \mathrm{UV} / \mathrm{O}_{3} / \mathrm{H}_{2} \mathrm{O}_{2}, \mathrm{O}_{3}, \mathrm{O}_{3} / \mathrm{H}_{2} \mathrm{O}_{2}$ \\
\hline $\mathrm{O}_{2} \cdot$ & $\mathrm{UV} / \mathrm{O}_{3}, \mathrm{UV} / \mathrm{O}_{3} / \mathrm{H}_{2} \mathrm{O}_{2}, \mathrm{O}_{3}, \mathrm{O}_{3} / \mathrm{H}_{2} \mathrm{O}_{2}$ \\
\hline
\end{tabular}

\subsubsection{Sonolysis}

Application of ultrasound irradiation (US) or sonolysis in water and wastewater treatment is fairly new and received less attention than other AOPs. However, in recent years, the number of research studies regarding employment of US waves for wastewater treatment is increasing considerably. Several advantages of sonolysis process such as avoiding consumption of chemical oxidants or catalysts, safety, and lower demand for clarification of aqueous solution, make their application simple and desired (Song et al., 2005). Sonochemical reactions are principally due to a phenomenon named acoustic cavitation. The phenomenon is the process of formation, expansion and sudden implosion of gas micro-bubbles. The acoustic cavitation leads to the generation of high local pressure $(>1000 \mathrm{~atm})$ and temperature $(>5000 \mathrm{~K})$. It is known that under 
these extreme conditions, pyrolysis of water molecules results in formation of hydroxyl radicals as follows (Petrier et al., 1994; Torres et al., 2008; Na et al., 2012):

$$
\mathrm{H}_{2} \mathrm{O} \stackrel{\mathrm{US}}{\longrightarrow} \mathrm{H}+{ }^{\bullet} \mathrm{OH}
$$

Generally, US waves at frequencies in the range of 20 to $1000 \mathrm{kHz}$ can produce cavitation in aqueous solutions (Duran et al., 2013). Cavitation acts as a means of concentrating the diffusing energy of ultrasound into microbubbles. During sonolysis, three types of sonochemical reactions can take place. First, the pyrolytic reactions which happen due to the high pressure and temperature inside the cavitation bubbles; second, free radical attack which is performed by the produced reactive radicals in the interfacial area between the bubbles and the liquid phase, and third, generation of hydroxyl radical in the liquid bulk solution (Vinodgopal and Peller, 2003; Emery et al., 2005). Organics components with low solubility and/or high volatility are expected to go through fast sonochemical degradation since they have a tendency to accumulate inside or around the gas-liquid interface. Due to this fact, sonolysis may be a proper method for removal of pharmaceutical micropollutants.

Factors that are effective in degradation via sonolysis are ultrasound frequency and intensity, $\mathrm{pH}$, temperature, the geometry of the sonoreactor, type and amount of the dissolved gas, nature and quantity of the pollutants and the water matrix (Klavarioti et al., 2009).

Sonolysis have been used by several researchers for elimination of pharmaceutical components from water.

In 2005, Emery's group, studied the degradation of triphenylphosphine oxide in deionized water using US irradiation. They found first order degradation rate constants which were increased by elevating the output power. The degradation of diclofenac was also studied by Hartmann et al. (2008). More than $90 \%$ degradation was observed after 60 min sonolysis. Increasing the 
frequency more than $617 \mathrm{kHz}$, decreased the degradation rate. Gao et al. (2013) investigated the effect of operating parameters on the degradation of sulfamethazine through sonolysis. Their studies showed that the degradation rate constant increased by increasing power and initial concentration of the compound. Also improved results were observed by the addition of oxygen and argon to the reactor. However, nitrogen reduced the degradation rate.

Treatment efficacies with sonolysis were not always satisfactory. Gogateand and Pandit, (2004) mentioned that degradation rates are much higher in AOPs such as Fenton comparing to sonolysis. Moahejrani et al. (2010) also observed a marginal degradation rate of hydrophilic compounds using US irradiation. Maezawa et al. (2007) reported only 13\% TOC reduction in the treatment of dye wastewater by sonolysis. This low efficiency could be attributed to two major factors. Some researches recommended that long irradiation time in the range 5-6 h leads to significant degradation via sonolysis (Martins et al., 2006). The other important factor is the recombination of reactive radicals to form stable components such as hydrogen peroxide and water according to the following reactions (Stock et al., 2000):

$$
\begin{aligned}
& \cdot \mathrm{OH}+{ }^{\bullet} \mathrm{OH} \rightarrow \mathrm{H}_{2}+\mathrm{O}_{2} \\
& \cdot \mathrm{OH}_{(a q)}+{ }^{\cdot} \mathrm{OH}_{(a q)} \rightarrow \mathrm{H}_{2} \mathrm{O}_{2} \\
& \mathrm{H}^{\bullet}+{ }^{\cdot} \mathrm{OH} \rightarrow \mathrm{H}_{2} \mathrm{O}
\end{aligned}
$$

The occurrence of these reactions decreases the contact between organic pollutants and radicals. In order to counteract this problem, the combination of sonolysis with other AOPs such as photocatalysis, photolysis, and ozonation has been proposed and used by several authors (Zhou et al., 2013; Destaillats et al., 2000; He et al., 2009). One of the common types of these combinations is sonophotolysis used in this study as completely explained in the following section. 


\subsubsection{Combination of photolysis and sonolysis (Sonophotolysis)}

Sonophotolysis is the combination of UV radiation and US waves in the absence of any catalyst (Joseph et al., 2009). If a catalyst used, the process is called sonophotocatalysis. Depending on the type of catalysts, sonophotocatalytic processes can be divided into two groups of homogenous $\left(\mathrm{O}_{3}, \mathrm{H}_{2} \mathrm{O}_{2}, \mathrm{Fe}^{2+}\right)$ and heterogeneous $\left(\mathrm{TiO}_{2}, \mathrm{ZnO}_{2}\right)$. The main concern of this section is on sonophotolysis in the presence of hydrogen peroxide process which is used in this study. During sonophotolysis combining the two processes can help to conquer the disadvantages of each one and achieve higher removal efficiency. Slow mineralization rate is the major problem associated with the application of sonoloysis in wastewater treatment. Also, the formation of toxic intermediates is a major problem while applying photolysis. On the other hand, during sonophotolysis, due to the simultaneous US and UV irradiation, more reactive radicals will be produced and consequently the degradation rate of organics would increase. Additionally, this elevated rate of mineralization causes in the reduction of intermediate components.

Operating factors such as US frequency and power, $\mathrm{pH}$, and dissolved gas, which are effective in the efficiency of sonolysis, have important roles in sonophotolytic process as well. Additionally UV light intensity has a key role in sonophotolytic process. Based on the wavelength UV lights can be divided into four classes of VUV (100-200 nm), UV-C (200-280 nm), UV-B (280-315 $\mathrm{nm}$ ), and UV-A (280-315 nm). The UV light in the wavelength range of 200 to $280 \mathrm{~nm}$ is used to produce hydroxyl radicals in the presence of hydrogen peroxide according to the following reaction:

$$
\mathrm{H}_{2} \mathrm{O}_{2} \stackrel{U V}{\longrightarrow} \mathrm{OH}+{ }^{\bullet} \mathrm{OH}
$$


Other than Reactions (2.5) through (2.9), some other reaction may take place during sonophotolysis. They are shown in Reactions (2.10) to (2.13) as follows:

$$
\begin{aligned}
& \mathrm{H}_{2} \mathrm{O}_{2}+{ }^{\bullet} \mathrm{OH} \rightarrow \mathrm{H}_{2} \mathrm{O}+\mathrm{HO}_{2}^{\circ} \\
& \mathrm{TOC}+h v \rightarrow \text { intermedia tes } \rightarrow \mathrm{CO}_{2}+\mathrm{H}_{2} \mathrm{O} \\
& \mathrm{TOC}+\mathrm{US} \rightarrow \text { intermedia tes } \rightarrow \mathrm{CO}_{2}+\mathrm{H}_{2} \mathrm{O} \\
& \mathrm{TOC}+{ }^{\circ} \mathrm{OH} \rightarrow \text { intermedia tes } \rightarrow \mathrm{CO}_{2}+\mathrm{H}_{2} \mathrm{O}
\end{aligned}
$$

In order to compare the efficiency of combined process in pollutant removal with respect to individual process, a parameter called synergic effect is used. The synergic effect in case of sonophotolysis is defined as:

Synergiceffect $=\frac{\text { Sonophotoly sis rate const. }}{\text { Sonolysisrate const. }+ \text { Photolysis rate const } .}$

Several studies have reported this parameter in order to demonstrate the advantages of combined processes. Some of these studies are shown in Table 2.8.

Treatment of pharmaceutical wastewater through sonophotolysis has not been reported frequently in the open literature. Therefore, much attention should be given to this subject. Some of these studies are discussed in the Chapter 4. Most of the studies have been performed under sonophotocatalysis using catalysts such as $\mathrm{TiO}_{2}$ (Hapeshi et al., 2013; Ahmedchekkat et al., 2011; Augugliaro et al., 2006). 
Table 2.8. Synergic effect in the sonophotolysis processes.

\begin{tabular}{|c|c|c|c|c|}
\hline Pollutant & $\begin{array}{c}\text { US (frequency, } \\
\text { power) }\end{array}$ & $\begin{array}{l}\text { UV (wave } \\
\text { length) }\end{array}$ & Synergic effect & Reference \\
\hline Phenol & $30 \mathrm{kHz}, 20 \mathrm{~W}$ & $253.7 \mathrm{~nm}$ & $\begin{array}{l}\text { Synergic effect } \\
\text { in TOC removal }\end{array}$ & $\begin{array}{l}\text { Molinari et al., } \\
2006\end{array}$ \\
\hline Phenol & $300 \mathrm{kHz}, 25 \mathrm{~W}$ & $254 \mathrm{~nm}$ & No & $\begin{array}{l}\text { Kidak and Ince, } \\
2007\end{array}$ \\
\hline Phenol & $25 \mathrm{kHz}, 1000 \mathrm{~W}$ & $365 \mathrm{~nm}$ & No & $\begin{array}{l}\text { Khokhawla and } \\
\text { Gogate, } 2010\end{array}$ \\
\hline Biosphenol-A & $300 \mathrm{kHz}, 80 \mathrm{~W}$ & $254 \mathrm{~nm}$ & $\begin{array}{l}\text { Synergic effect } \\
\text { in TOC and } \\
\text { COD removal }\end{array}$ & $\begin{array}{l}\text { Torres et al., } \\
2008\end{array}$ \\
\hline $\begin{array}{l}\text { Acid Orange } 7 \\
\text { dye (AO7) }\end{array}$ & $520 \mathrm{kHz}, 600 \mathrm{~W}$ & $253.7 \mathrm{~nm}$ & $\begin{array}{l}\text { Synergic effect } \\
\text { in TOC removal }\end{array}$ & $\begin{array}{l}\text { Tezcanli Guyer } \\
\text { and Ince, } 2003\end{array}$ \\
\hline 4-Chlorophenol & $\begin{array}{c}516 \mathrm{kHz}, 15.2- \\
38.3 \mathrm{~W}\end{array}$ & $254 \mathrm{~nm}$ & $\begin{array}{c}\text { Synergic effect } \\
\text { in component } \\
\text { degradation }\end{array}$ & $\begin{array}{l}\text { Hamdaoui and } \\
\text { Naffrecheoux, } \\
2008\end{array}$ \\
\hline $\begin{array}{l}\text { Malachite green } \\
\text { (Dye) }\end{array}$ & $35 \mathrm{kHz}, 49 \mathrm{~W}$ & $253 \mathrm{~nm}$ & $\begin{array}{c}\text { Synergic effect } \\
\text { in component } \\
\text { degradation }\end{array}$ & $\begin{array}{l}\text { Behnajady et al., } \\
2008\end{array}$ \\
\hline $\begin{array}{l}\text { Trichloroacetic } \\
\text { acid }\end{array}$ & $30 \mathrm{kHz}, 20.4 \mathrm{~W}$ & $253.7 \mathrm{~nm}$ & No & Wu et al., 2001 \\
\hline
\end{tabular}

\subsubsection{Combination of advanced oxidation and biological processes for wastewater treatment}

The main pathways to eliminate contaminants from aqueous solutions are biodegradation and photodegradation (Oller et al., 2011). Conventional biological treatments are known as the most 
common option for the treatment of various types of wastewater. Generally, these methods are cheap and simple to employ. However, it has been proved that several industries such as pharmaceuticals generate waste streams that include refractory and nonbiodegradable compounds. So a satisfactory effluent cannot be achieved through biodegradation. On the other hand, advanced technologies such as AOPs have been proved to be significantly efficient in the treatment of almost all type of pollutants. Therefore, these methods could be applied to those recalcitrant and nonbiodegrdable compounds. However, these advanced methods are associated with high consumption of compounds as catalyst or oxidant and high electrical power. To overcome aforementioned problems and find efficient and economical treatment, the combination of advanced oxidation and biological processes as a potential alternative has attracted attention of many researchers. In these combination treatments, generally, AOPs are applied as a pre-treatment to degrade the refractory compounds and improve the biodegradability level of the wastewater. Finding the optimum retention time of the wastewater in AOP reactor is a challenging issue. On one side, in order to reduce the cost of the AOPs, lower dosage of chemicals and lower retention times should be applied to achieve small percentage of mineralization, on the other hand, very low mineralization causes the formation of intermediates which are still toxic and similar to the parent compounds. Therefore, the selection of the point to transfer the effluent of AOP reactor to the bioreactor should be performed carefully. Two factors must be considered in this integrated process. First is the biodegradability of wastewater after chemical oxidation, and second, presence of residual oxidant/catalysts which are inhibitory for microorganism applied in bioreactors.

There is also another case while combination of AOPs with biological treatments. If the original wastewater contains a great amount of biodegradable compounds, the biological pre-treatment 
can be used to remove the biodegradable portion of the pollutants. This could be followed by an AOP as post treatment to convert the refractory compounds to biodegradable intermediates.

Several studies have been reported for the integrated processes (Tabrizi and Mehrvar, 2004; Oller et al., 2011). A summary of these experimental works, especially those dealing with multicomponent and real industrial wastewater are presented in Tables 2.9 and 2.10.

\subsubsection{Parameters for measuring biodegradability of wastewater samples}

Analysis of biodegradability of wastewater samples has great importance especially while applying AOPs as pre-treatment for biological systems. Several parameters are used to observe biodegradability. The most common ones are (Sarria et al., 2003):

- General parameters such as TOC, BOD, and COD;

- $\mathrm{BOD}_{5} / \mathrm{COD}$ ratio, this ratio is an approximate index of the fraction of the organic compounds in the wastewater sample that could be treated under aerobic biological system in a certain period of time (5 days). Increasing the ratio implies higher biodegradability.

- Average oxidation state (AOS), as it can be calculated by Equation (2.15). It should be noted that in the equation, COD and TOC are based on molar values. AOS is a very helpful parameter for estimating the oxidation degree of mixed solutions and provides indirect data about biodegradability of the solutions. AOS may vary between 4 (for $\mathrm{CO}_{2}$, the most oxidized state of carbon) and -4 (for $\mathrm{CH}_{4}$, the most reduced state of carbon) (Scott and Ollis, 1995).

$$
A O S=\frac{4(T O C-C O D)}{T O C}
$$


- Oxygen uptake by respirometry instrument which determines the oxygen consumed by microorganisms during growth which can be related to BOD value (Lagarde et al., 2005).

\subsubsection{Concluding remarks}

In this chapter, characteristics of pharmaceutical wastewater as well as various treatment options was reviewed.

Conventional biological treatments are the most common option for removal of PPCPs from wastewater. Their poor results in some cases persuade researchers to apply novel technologies. AOPs are one of these new treatments methods which have indicated high efficiency for elimination of various contaminants from water matrices. However, the high costs associated with their application prevent their wide usage in industrial scale.

Combining AOPs and biological systems seems a great alternative to achieve high treatment ability along with lower cost. In this chapter several examples of such combination was provided (Tables 9 and 10). In most of these studies, the combination of processes improved the efficiency of individual treatment. TOC and COD removals up to $99 \%$ were observed in some these studies. Therefore, according to the information found from literature and also considering the characteristics of the synthetic pharmaceutical wastewater, the combination of sonophotolysis and activated sludge processes was chosen as the treatment method. Results obtained from this work can assist to extend the information on the combined AOPs and biological, its performance and capability in removing TOC, TN, and COD from pharmaceutical wastewater 
Table 2.9. Summary of research works which used combination of AOPs and biological methods for treatment of multicomponent pharmaceutical wastewater (AOP as post-treatment).

\begin{tabular}{|c|c|c|c|c|c|c|}
\hline & $\begin{array}{l}\text { Type of } \\
\text { Wastewater }\end{array}$ & AOP step & $\begin{array}{l}\text { Biological } \\
\text { step }\end{array}$ & $\begin{array}{l}\text { Measured } \\
\text { Parameters }\end{array}$ & Results & Reference \\
\hline 1 & $\begin{array}{l}\text { Secondary effluent } \\
\text { from a MWTP } \\
\text { contains } 32 \text { PPCPs }\end{array}$ & $\begin{array}{l}\mathrm{UV}, \mathrm{UV} / \mathrm{H}_{2} \mathrm{O}_{2}, \\
\text { Fenton, } \\
\text { Photo-Fenton }\end{array}$ & $\begin{array}{l}\text { Activated } \\
\text { sludge }\end{array}$ & $\begin{array}{l}\text { Degradation of } \\
\text { the } \\
\text { components, } \\
\text { TOC,COD }\end{array}$ & $\begin{array}{l}97 \% \text { total degradation after } 30 \mathrm{~min} \\
\mathrm{UV} / \mathrm{H}_{2} \mathrm{O}_{2} \text { and complete degradation } \\
\text { after } 90 \mathrm{~min} \text { of photo-Fenton process }\end{array}$ & De la Cruz et al., 2012 \\
\hline 2 & $\begin{array}{lr}\text { Municipal } & \text { effluent } \\
\text { contains } 6 & \text { estrogens } \\
\text { and } & \text { estrogenic } \\
\text { phenols } & \\
\end{array}$ & Ozonation & $\begin{array}{l}\text { Moving bed } \\
\text { biofilm } \\
\text { reactor }\end{array}$ & $\begin{array}{l}\text { TOC,BOD } \\
\text { Elimination of } \\
\text { estrogens }\end{array}$ & $\begin{array}{l}96 \% \text { TOC removal was reported after } \\
\text { combined process, } 5 \text { estrogens } \\
\text { removed more than } 99 \%\end{array}$ & Gunnarsson et al., 2009 \\
\hline 3 & $\begin{array}{l}\text { Secondary effluent } \\
\text { from a MWTP } \\
\text { contains } 41 \text { PPCPs }\end{array}$ & $\mathrm{UV}, \mathrm{UV} / \mathrm{H}_{2} \mathrm{O}_{2}$ & $\begin{array}{l}\text { Activated } \\
\text { sludge }\end{array}$ & $\begin{array}{l}\text { Elimination of } \\
\text { detected } \\
\text { components }\end{array}$ & $\begin{array}{l}\text { Only } 12 \text { components degrade } \\
\text { efficiently in UV process alone with } \\
\text { high UV energy. In UV/ } \mathrm{H}_{2} \mathrm{O}_{2} 90 \% \\
\text { removal efficiency could be achieved } \\
\text { for } 39 \text { components with lower UV } \\
\text { dose. }\end{array}$ & Kim et al., 2009 \\
\hline 4 & \begin{tabular}{|l|} 
Municipal waste \\
water contains 30 \\
PPCPs \\
\end{tabular} & Ozonation & $\begin{array}{l}\text { Activated } \\
\text { sludge }\end{array}$ & $\begin{array}{l}\text { Elimination of } \\
\text { selected } \\
\text { components }\end{array}$ & $\begin{array}{l}\text { Almost all of the selected components } \\
\text { degrade more than } 90 \% \text { after } \\
\text { combined process. }\end{array}$ & Schaar et al., 2010 \\
\hline 5 & $\begin{array}{l}\text { Municipal waste } \\
\text { water contains } 25 \\
\text { PPCPs }\end{array}$ & Ozonation & $\begin{array}{l}\text { Activated } \\
\text { sludge }\end{array}$ & $\begin{array}{l}\text { Elimination of } \\
\text { selected } \\
\text { components }\end{array}$ & $\begin{array}{l}\text { Ozonation improve the removal } \\
\text { efficiency, especially for some } \\
\text { components which are recalcitrant to } \\
\text { biological treatment }\end{array}$ & Rosal et al., 2010 \\
\hline 6 & $\begin{array}{l}\text { Secondary effluent } \\
\text { from a municipal } \\
\text { STP contains } 24 \\
\text { PPCPs }\end{array}$ & $\begin{array}{l}\text { Ozonation, } \\
\text { (Sand } \\
\text { filtration) }\end{array}$ & $\begin{array}{l}\text { Activated } \\
\text { sludge }\end{array}$ & $\begin{array}{l}\text { Elimination of } \\
\text { detected } \\
\text { components, }\end{array}$ & $\begin{array}{l}\text { The combination of ozonation and } \\
\text { sand filtration with activated sludge } \\
\text { treatment gave about } 80 \% \text { removal of } \\
\text { all the target compounds except } \\
\text { carbamazepine and diethyltoluamide. }\end{array}$ & Nakada et al., 2007 \\
\hline 7 & $\begin{array}{l}\text { Waste water from } \\
\text { secondary clarifier } \\
\text { of two MWTP, } 32 \\
\text { PPCPs were }\end{array}$ & $\mathrm{O}_{3}, \mathrm{O}_{3} / \mathrm{H}_{2} \mathrm{O}_{2}$ & $\begin{array}{l}\text { Activated } \\
\text { sludge }\end{array}$ & $\begin{array}{l}\text { TOC, } \\
\text { Elimination of } \\
\text { detected } \\
\text { components }\end{array}$ & $\begin{array}{l}\text { TOC removal increased from } 15 \% \text { to } \\
90 \% \text { after addition of } \mathrm{H}_{2} \mathrm{O}_{2} \text {. After } 5 \\
\text { min } \mathrm{O}_{3} / \mathrm{H}_{2} \mathrm{O}_{2} \text { treatment except } 2 \\
\text { PPCPs, others were eliminated more }\end{array}$ & Rosal et al., 2008 \\
\hline
\end{tabular}




\begin{tabular}{|c|c|c|c|c|c|c|}
\hline & detected. & & & & than $99 \%$. & \\
\hline 8 & $\begin{array}{l}\text { DW, Raw municipal } \\
\text { wastewater, } 4 \\
\text { PPCPs were } \\
\text { detected }\end{array}$ & $\begin{array}{l}\mathrm{O}_{3}, \mathrm{O}_{3} / \mathrm{UV} \\
\mathrm{H}_{2} \mathrm{O}_{2} / \mathrm{UV}\end{array}$ & $\begin{array}{l}\text { Activate } \\
\text { sludge, } \\
\text { Membrane } \\
\text { bioreactor }\end{array}$ & $\begin{array}{l}\text { Elimination of } \\
\text { detected } \\
\text { components }\end{array}$ & $\begin{array}{l}\text { Diclofenac, Clofibric acid and } \\
\text { Carbamazepine were removed more } \\
\text { than } 90 \% \text { in combined Active sludge } \\
\text { and all three AOPs, while for } \\
\text { Diazepam removal efficiency varied } \\
\text { between } 53 \% \text { to } 77 \% \text {. }\end{array}$ & Gebhardt and Schroder, 2007 \\
\hline 9 & $\begin{array}{l}\text { Secondary effluent } \\
\text { from MWTP, } 15 \\
\text { PPCPs were } \\
\text { detected }\end{array}$ & Photo-Fenton & $\begin{array}{l}\text { Activate } \\
\text { sludge }\end{array}$ & $\begin{array}{l}\text { Elimination of } \\
\text { detected } \\
\text { components, } \\
\text { DOC, }\end{array}$ & $\begin{array}{l}\text { Three different approaches of Photo- } \\
\text { Fenton process were tested and } \\
\text { compared. Adding } 10 \mathrm{mg} \text { Humic Acid } \\
\text { to Fenton reactor indicated better } \\
\text { degradation of detected contaminants. }\end{array}$ & Klamerth et al., 2011 \\
\hline 10 & $\begin{array}{l}\text { A real } \\
\text { pharmaceutical } \\
\text { Wastewater from } \\
\text { the production of } \\
\text { Acyclovir. }\end{array}$ & Ozonation & $\begin{array}{l}\text { MBR( } \\
\text { Membrane } \\
\text { bioreactor) }\end{array}$ & $\begin{array}{l}\text { COD, } \\
\text { Acyclovir } \\
\text { concentration }\end{array}$ & $\begin{array}{l}\text { In this work ozonation was placed in } \\
\text { MBR recirculation system. It was an } \\
\text { integrated system. } 99 \% \text { COD removal } \\
\text { was obtained in MBR, ozonation did } \\
\text { not have any significant effect. Adding } \\
\text { ozonation, improved organic } \\
\text { components removal from } 20 \% \text { to } \\
60 \% \text {. }\end{array}$ & Mascolo et al., 2010 \\
\hline 11 & $\begin{array}{l}\text { Urban wastewater } \\
\text { treatment plant } \\
\text { effluent } \\
\text { contaminated with } \\
\text { amoxicillin, } \\
\text { carbamazepine and } \\
\text { diclofenac } \\
\end{array}$ & $\begin{array}{l}\mathrm{TiO}_{2} \\
\text { photocatalysis }\end{array}$ & $\begin{array}{l}\text { Activate } \\
\text { sludge }\end{array}$ & $\begin{array}{l}\text { UV } \\
\text { absorbance, } \\
\text { TOC }\end{array}$ & $\begin{array}{l}\text { TOC removal under photocatalysis } \\
\text { with } 0.8 \mathrm{gr} \mathrm{TiO}_{2} \text { was different for each } \\
\text { of PPCPs and ranged between } 60 \% \\
\text { and } 90 \% \text {.Applied process was not able } \\
\text { to reduce the toxicity compeletly. }\end{array}$ & Rizzo et al., 2009 \\
\hline 12 & $\begin{array}{l}\text { Effluent of sewage } \\
\text { treatment plant } \\
\text { polluted with } \\
\text { amoxicillin, } \\
\text { bezafibrate and } \\
\text { paracetamol }\end{array}$ & $\begin{array}{l}\text { Photo-Fenton } \\
\text { (Black light } \\
\text { lamp and } \\
\text { solar } \\
\text { irradiation) }\end{array}$ & $\begin{array}{l}\text { Activate } \\
\text { sludge }\end{array}$ & $\begin{array}{l}\text { TOC, } \\
\text { degradation of } \\
\text { pollutants }\end{array}$ & $\begin{array}{l}\text { Solar radiation was more efficient that } \\
\text { black light in degrading contaminates } \\
\text { Influence of waster matrix and reagent } \\
\text { dose in mineralization of target } \\
\text { components were studied. }\end{array}$ & Trovo et al., 2008 \\
\hline 13 & $\begin{array}{l}\text { Synthetic } \\
\text { slaughterhouse } \\
\text { wastewater }\end{array}$ & $\mathrm{UV} / \mathrm{H}_{2} \mathrm{O}_{2}$ & $\begin{array}{l}\text { Activated } \\
\text { sludge }\end{array}$ & $\begin{array}{l}\text { TOC, TN, } \\
\text { BOD }\end{array}$ & $\begin{array}{l}99.98 \% \text { TOC, } 82.84 \% \mathrm{TN} \text {, and } \\
99.69 \% \text { CBOD5 removal was } \\
\text { achieved }\end{array}$ & Bustillo-Lecompte et al., 2013 \\
\hline
\end{tabular}


Table 2.10. Summary of research works which used combination of AOPs and biological methods for treatment of multicomponent pharmaceutical wastewater (AOP as pre-treatment).

\begin{tabular}{|c|c|c|c|c|c|c|}
\hline & Type of Wastewater & AOP step & $\begin{array}{l}\text { Biological } \\
\text { step }\end{array}$ & $\begin{array}{l}\text { Measured } \\
\text { Parameters }\end{array}$ & Results & Reference \\
\hline 1 & $\begin{array}{l}\text { Industrial } \\
\text { pharmaceutical } \\
\text { wastewater contains } 6 \\
\text { PPCPs }\end{array}$ & Fenton & $\begin{array}{l}\text { Activated } \\
\text { Sludge }\end{array}$ & $\begin{array}{l}\text { TOC, } \\
\text { COD,BOD, } \\
\text { Degradation of } \\
\text { detected } \\
\text { refractory } \\
\text { components }\end{array}$ & $\begin{array}{l}\text { BOD/COD increased from } 0.25 \text { to } 0.57,92 \% \\
\text { COD removal and } 90 \% \text { TOC removal }\end{array}$ & $\begin{array}{l}\text { Badawy et } \\
\text { al.,2009 }\end{array}$ \\
\hline 2 & $\begin{array}{l}\text { Industrial } \\
\text { pharmaceutical } \\
\text { wastewater contains } \\
\text { nalidixic acid }\end{array}$ & $\begin{array}{l}\text { Solar photo- } \\
\text { Fenton }\end{array}$ & $\begin{array}{l}\text { Immobilized } \\
\text { Biomass } \\
\text { reactor(IBR) }\end{array}$ & $\begin{array}{l}\text { DOC,COD and } \\
\text { nalidixic acid } \\
\text { degradation }\end{array}$ & $95 \%$ DOC removal & $\begin{array}{l}\text { Sitori et al., } \\
2009\end{array}$ \\
\hline 3 & $\begin{array}{l}\text { Raw swine wastewater } \\
\text { from feeding plant } \\
\text { wastewater contains } \\
\text { six detected antibiotics }\end{array}$ & Fenton & $\begin{array}{l}\text { Sequencing } \\
\text { Batch } \\
\text { reactor(SBR }\end{array}$ & $\begin{array}{l}\text { TOC, } \\
\text { Degradation of } \\
\text { antibiotics }\end{array}$ & $\begin{array}{l}\text { SBR pretreatment removed } 95 \% \text { of COD, } \\
\text { Fenton process remove } 47 \% \text { of TOC and } \\
\text { degrade all detected antibiotics from } \\
\text { pretreated wastewater }\end{array}$ & $\begin{array}{l}\text { Ben et al., } \\
2009\end{array}$ \\
\hline 4 & $\begin{array}{l}\text { Raw sewage sludge } \\
\text { spiked with different } \\
\text { concentrations of } 11 \\
\text { PPCPs }\end{array}$ & Ozonation & $\begin{array}{l}\text { Anaerobic } \\
\text { digestion }\end{array}$ & $\begin{array}{l}\text { COD, } \\
\text { degradation of } \\
\text { target } \\
\text { components }\end{array}$ & $\begin{array}{l}\text { Ozonation improved COD solubilization by } \\
60 \% \text { which leads to better NOM removal } \\
\text { efficiency during biotreatment }\end{array}$ & $\begin{array}{l}\text { Carballa et } \\
\text { al., } 2007\end{array}$ \\
\hline 5 & $\begin{array}{l}\text { Effluents of } 3 \text { different } \\
\text { WWTP which contain } \\
21 \text { detected PPCPs }\end{array}$ & Ozonation & $\begin{array}{l}\text { Biological } \\
\text { Activated } \\
\text { Carbon (BAC) }\end{array}$ & $\begin{array}{l}\text { DOC, } \\
\text { Elimination of } \\
\text { detected } \\
\text { components }\end{array}$ & $\begin{array}{l}\text { Up to } 50 \% \text { DOC removal and more than } \\
90 \% \text { removal of the majority of detected } \\
\text { components }\end{array}$ & $\begin{array}{l}\text { Reungoat et } \\
\text { al., } 2012\end{array}$ \\
\hline 6 & $\begin{array}{l}\text { Real wastewater, } \\
\text { contains } 2 \text { antibiotics of } \\
\text { amoxicillin and } \\
\text { cloxacillin }\end{array}$ & $\mathrm{TiO}_{2} / \mathrm{UV} / \mathrm{H}_{2} \mathrm{O}_{2}$ & $\begin{array}{l}\text { Sequencing } \\
\text { Batch } \\
\text { reactor(SBR), }\end{array}$ & $\begin{array}{l}\text { COD, DOC, } \\
\text { Degradation of } \\
\text { the antibiotics }\end{array}$ & $\begin{array}{l}\text { In } \mathrm{TiO}_{2} / \mathrm{UV} / \mathrm{H}_{2} \mathrm{O}_{2} \text { process the antibiotics } \\
\text { remove completely after } 30 \mathrm{~min} \text {. The } \\
\text { combined process remove COD only } 57 \% \text {. }\end{array}$ & $\begin{array}{l}\text { Elmolla and } \\
\text { Chaudhuri } \\
2011\end{array}$ \\
\hline 7 & $\begin{array}{l}\text { Real wastewater, } \\
\text { contains } 2 \text { antibiotics }\end{array}$ & Fenton & $\begin{array}{l}\text { Sequencing } \\
\text { Batch } \\
\text { reactor(SBR }\end{array}$ & $\begin{array}{l}\text { COD, DOC, } \\
\text { Degradation of } \\
\text { the antibiotics }\end{array}$ & $\begin{array}{l}\text { At optimum condition, } 89 \% \text { removal of } \\
\text { COD was achieved by the combined } \\
\text { process. }\end{array}$ & $\begin{array}{l}\text { Elmolla and } \\
\text { Chaudhuri, } \\
2012\end{array}$ \\
\hline
\end{tabular}




\section{CHAPTER 3}

\section{MATERIALS AND METHODS}

\subsection{Introduction}

The goal of this study is to evaluate the performance and effectiveness of aerobic activated sludge and the $\mathrm{UV} / \mathrm{US} / \mathrm{H}_{2} \mathrm{O}_{2}$ processes, as well as their combination for reduction of TOC, TN, COD and BOD from the synthetic pharmaceutical wastewater. To achieve this goal, several experiments were conducted and the data was analyzed by means of different analytical methods.

\subsection{Materials}

\subsubsection{Synthetic pharmaceutical wastewater (SPWW)}

The synthetic wastewater used in this study was prepared based on a list of component reported in the study of Badawy et al. (2009). They detected the components in the wastewater generated by a pharmaceutical and chemical company in Cairo, Egypt. The wastewater contains chloramphenicol, diclofenac, salicylic acid and paracetamol which are the main products of the company. Also some by products such as nitrobenzene, benzoic acid and phenol were detected in the raw wastewater. Table 3.1 indicates the maximum and minimum concentration of each component present in the wastewater. It should be noted that in the study by Badawy et al.(2009), samples were taken six times during a year. 
Table 3.1.Concentration of pharmaceuticals in the raw wastewater

(Adapted from Badawy et al. 2009)

\begin{tabular}{lccc}
\hline \multicolumn{1}{c}{ Compound } & Maximum & Minimum & Mean \\
& Concentration(mg/L) & Concentration(mg/L) & Concentration(mg/L) \\
& & & \pm SD $^{*}$ \\
\hline p- Aminophenol & 142.94 & 0.14 & $62.94 \pm 72.94$ \\
\hline Paracetamol & 154.11 & 5.61 & $69.68 \pm 76.32$ \\
\hline Phenol & 295.79 & 0.51 & $130.18 \pm 150.69$ \\
\hline Chloramphenicol & 87.96 & 0.41 & $38.84 \pm 44.74$ \\
\hline Diclofenac & 12.73 & 0.48 & $5.6 \pm 6.11$ \\
\hline Benzoic Acid & 152.44 & 2.51 & $67.91 \pm 76.78$ \\
\hline Salicylic Acid & 714.41 & 1.03 & $314.68 \pm 364.39$ \\
\hline Nitrobenzene & 74.64 & .05 & $32.84 \pm 38.12$ \\
\hline
\end{tabular}

*Standard Deviation.

In this study three sets of concentrations were chosen for conducting the experiments. Characteristics of these three sets are indicated in Table 3.2. The measured values of TOC, TN and COD are also mentioned in the Table 3.2. The theoretical values and methods of calculation of the theoretical values of are shown in Appendices A and B. Initial $\mathrm{pH}$ of the SPWW was 3.9 \pm 0.1 . Distilled water was used to prepare the synthetic wastewaters. Some physical properties of the components present in the wastewaters are shown in Table 3.3. 
Table 3.2. Composition of the SPWW used in this study

\begin{tabular}{|c|c|c|c|c|c|}
\hline Compound & $\begin{array}{l}\text { Molecular } \\
\text { Formula }\end{array}$ & $\begin{array}{l}\text { Molecular } \\
\text { Weight } \\
(\mathrm{g} / \mathrm{mol})\end{array}$ & $\begin{array}{l}\text { Concentration } \\
\text { in } 1^{\text {st }} \\
\operatorname{run}(\mathbf{m g} / \mathrm{L})\end{array}$ & $\begin{array}{l}\text { Concentration } \\
\text { in } 2^{\text {nd }} \\
\operatorname{run}(\mathrm{mg} / \mathrm{L})\end{array}$ & $\begin{array}{c}\text { Concentration } \\
\text { in } 3^{\text {rd }} \\
\operatorname{run}(\mathrm{mg} / \mathrm{L})\end{array}$ \\
\hline 4- Aminophenol & $\mathrm{C}_{6} \mathrm{H}_{7} \mathrm{NO}$ & 109.13 & 6.25 & 12.5 & 25 \\
\hline Paracetamol & $\mathrm{C}_{8} \mathrm{H}_{9} \mathrm{NO}_{2}$ & 151.17 & 2.5 & 5 & 10 \\
\hline Phenol & $\mathrm{C}_{6} \mathrm{H}_{6} \mathrm{O}$ & 94.11 & 12.5 & 25 & 50 \\
\hline Chloramphenicol & $\mathrm{C}_{11} \mathrm{H}_{12} \mathrm{C}_{12} \mathrm{~N}_{2} \mathrm{O}_{5}$ & 323.132 & 7.5 & 15 & 30 \\
\hline Benzoic Acid & $\mathrm{C}_{7} \mathrm{H}_{6} \mathrm{O}_{2}$ & 122.12 & 6.25 & 12.5 & 25 \\
\hline Salicylic Acid & $\mathrm{C}_{7} \mathrm{H}_{7} \mathrm{O}_{3} \mathrm{Na}$ & 160.11 & 28.75 & 57.5 & 115 \\
\hline $\begin{array}{l}\text { Diclofenac } \\
\text { Sodium }\end{array}$ & $\mathrm{C}_{14} \mathrm{H}_{11} \mathrm{Cl}_{12} \mathrm{NO}_{2} \mathrm{Na}$ & 318.1 & 0.5 & 1 & 2 \\
\hline Nitrobenzene & $\mathrm{C}_{6} \mathrm{H}_{5} \mathrm{NO}_{2}$ & 123.06 & 7.5 & 15 & 30 \\
\hline TOC (mg/L) & & & $44.83 \pm 0.25$ & $89.75 \pm 0.37$ & $179.33 \pm 0.35$ \\
\hline $\mathrm{TN}(\mathrm{mg} / \mathrm{L})$ & & & $2.56 \pm 0.08$ & $5.12 \pm 0.08$ & $10.25 \pm 0.12$ \\
\hline $\mathrm{COD}(\mathrm{mg} / \mathrm{L})$ & & & $127 \pm 1$ & $252 \pm 1$ & $515 \pm 1$ \\
\hline
\end{tabular}

\subsubsection{Hydrogen peroxide}

Hydrogen peroxide solution was purchased from Aldrich and was used as received. The solution was $30 \% \mathrm{w} / \mathrm{w}$ in water with the molecular weight of $34.01 \mathrm{~g} / \mathrm{mol}$ and the density of $1.11 \mathrm{~g} / \mathrm{cm}^{3}$. The solution must be kept in dark bottles to prevent decomposition. 
Table 3.3. Physical properties of the chemicals in the SPWW

\begin{tabular}{|c|c|c|c|c|c|c|}
\hline Compounds & CAS No. & Appearance & $\begin{array}{c}\text { Vapour } \\
\text { Pressure at } \\
20^{\circ} \mathrm{C}(\mathrm{mm} \\
\mathrm{Hg})\end{array}$ & $\begin{array}{c}\text { Boiling Point } \\
\left({ }^{\circ} \mathrm{C}\right)\end{array}$ & $\begin{array}{c}\text { Density } \\
(g / m L) \text { at } \\
2^{\circ} \mathrm{C}\end{array}$ & $\begin{array}{c}\text { Solubility } \\
(m g / L \text { in } \\
\text { water) at } 25^{\circ} \mathrm{C}\end{array}$ \\
\hline 4- Aminophenol & $123-30-8$ & $\begin{array}{l}\text { Crystalline- } \\
\text { Powder }\end{array}$ & N/A & 284 & 1.13 & 15000 \\
\hline Paracetamol & $103-90-2$ & $\begin{array}{l}\text { Crystalline- } \\
\text { Powder }\end{array}$ & N/A & $>500$ & 1.263 & 12780 \\
\hline Phenol & $108-95-2$ & $\begin{array}{l}\text { Colorless- } \\
\text { Crystal }\end{array}$ & 0.36 & 181.7 & 1.07 & 82000 \\
\hline Chloramphenicol & $56-75-7$ & White-Powder & N/A & 644.9 & 1.547 & 2500 \\
\hline Benzoic Acid & $65-85-0$ & $\begin{array}{l}\text { White- } \\
\text { Crystalline }\end{array}$ & 0.000750 & 249.2 & 1.265 & 2900 \\
\hline Salicylic Acid & $69-72-7$ & $\begin{array}{l}\text { Colorless- } \\
\text { Crystalline }\end{array}$ & 1 & 211 & 1.443 & 2000 \\
\hline $\begin{array}{l}\text { Diclofenac } \\
\text { Sodium }\end{array}$ & $\begin{array}{l}15307- \\
86-5\end{array}$ & White-Powder & $1.59 \mathrm{E}-07$ & 412 & 0.63 & 50000 \\
\hline Nitrobenzene & $98-95-3$ & $\begin{array}{l}\text { Yellowish } \\
\text { liquid }\end{array}$ & 0.15 & 210.9 & 1.20 & 2090 \\
\hline
\end{tabular}

\subsection{3 $\mathrm{NaOH}$ and $\mathrm{H}_{2} \mathrm{SO}_{4}$ solutions (1N)}

The $1 \mathrm{~N} \mathrm{NaOH}$ and $\mathrm{H}_{2} \mathrm{SO}_{4}$ solutions were purchased from VWR Canada and used as received. They were stored in an inflammable liquid cabinet away from heat source (below $20^{\circ} \mathrm{C}$ ). 


\subsection{Aerobic Inoculum}

The aerobic seed for activated sludge process was obtained from the Ashbridge Bay municipal wastewater treatment plant in Toronto, Canada. Eight liters of the aerobic sludge (with initial suspended solid (SS) concentration of $1750 \mathrm{mg} \mathrm{SS} / \mathrm{L})$ were loaded in the aerobic bioreactor $(25.5$ L capacity). In order to achieve higher TOC and TN removal, the inoculum was acclimatized to the components in the SPWW. In the acclimatization process, the inoculum was fed continuously with the wastewater for a period of thirty days. Also in order to have an alternate bioreactor, excess inoculum was kept in a closed container and fed with SPWW in room temperature.

\subsection{Experimental Setup}

The experimental setup for the integrated advanced oxidation and activated sludge processes is shown in Figure 3.1. The aerobic AS reactor was placed after the sonophotoreactor to make the combination process convenient. This order is due to the low biodegradability of the pharmaceutical wastewater.

Figure 3.2 shows the schematic diagram of the experimental setup. The sonophotoreactror is an airlift external loop reactor. Airlift reactors are categorized as pneumatically agitated devices. Usually they do not have any internal stirring device and use gases such as air and ozone to supply mixing. They are characterized by fluid circulation in a specific cyclic pattern. The main feature of airlift reactors is the fluid dynamic in all sections of the reactor. Airlift reactors are generally divided into two groups: external loops and baffled vessels. External loops are kind of vessels that circulation happens through distinct conduits. In baffled vessels, some baffles are added inside the vessel to build the channels which are required for cyclic circulation. 
Both types of airlift reactors consist of four major parts: riser, downcomer, base or bottom connecting and gas sparger. Riser is the part in which the flow is mainly upward and gas is sparged into the reactor from its base section. Downcomer is generally parallel to the riser. The riser and the downcomer are connected to each other to form a loop. The liquid with lower gas portion enters the downcommer from riser. Finally, the bottom connecting part allows liquid circulation between riser and downcommer (Mohajerani, 2012; Chisiti et al. 1988).

The riser is $9.72 \mathrm{~cm}$ in diameter and $110 \mathrm{~cm}$ in height. For the downcomer, height and diameter are 90 and 3.25, respectively. Also, the total volume of the reactor is $7 \mathrm{~L}$. The sonophotoreactor was employed in both batch and continuous modes. As shown in Figure 3.1, the setup is equipped with a single ended UV lamp (Ushio America Inc.) and a commercial ultrasonic processor (Branson, S-250D sonifier). The UV lamp is $84.6 \mathrm{~cm}$ in height and $1.55 \mathrm{~cm}$ in diameter and operates at $253.7 \mathrm{~nm}$ wavelength with $13 \mathrm{~W}$ output power and is located inside the riser. The sonifier has a $13 \mathrm{~mm}$ diameter tip which is capable of working in continuous and pulse mode. It has a constant frequency of $20 \mathrm{kHz}$ and a variable output power up to $200 \mathrm{~W}$. In this study, all experiments were performed with sonifier at continuous mode. To inject air into the riser, there is a perforated circular tube air sparger $5 \mathrm{~cm}$ above the reactor bottom. The sparged air enhances mixing in the reactor. Temperature in the reactor was also monitored. The aerobic AS reactor is a continuous flow completely mixed flow mixed activated sludge reactor with an effective volume of $25.5 \mathrm{~L}$ working under ambient condition. The reactor composed of two parts; the aeration tank and the clarifier for separation of liquid and solid. Aeration is crucial operation while working with aerobic reactors. Diffused air was used to provide aeration and also mixing in the reactor. The amount of DO must be kept over $2 \mathrm{mg} / \mathrm{L}$ in order to prevent anaerobic reactions (Zhang et al., 2009) 


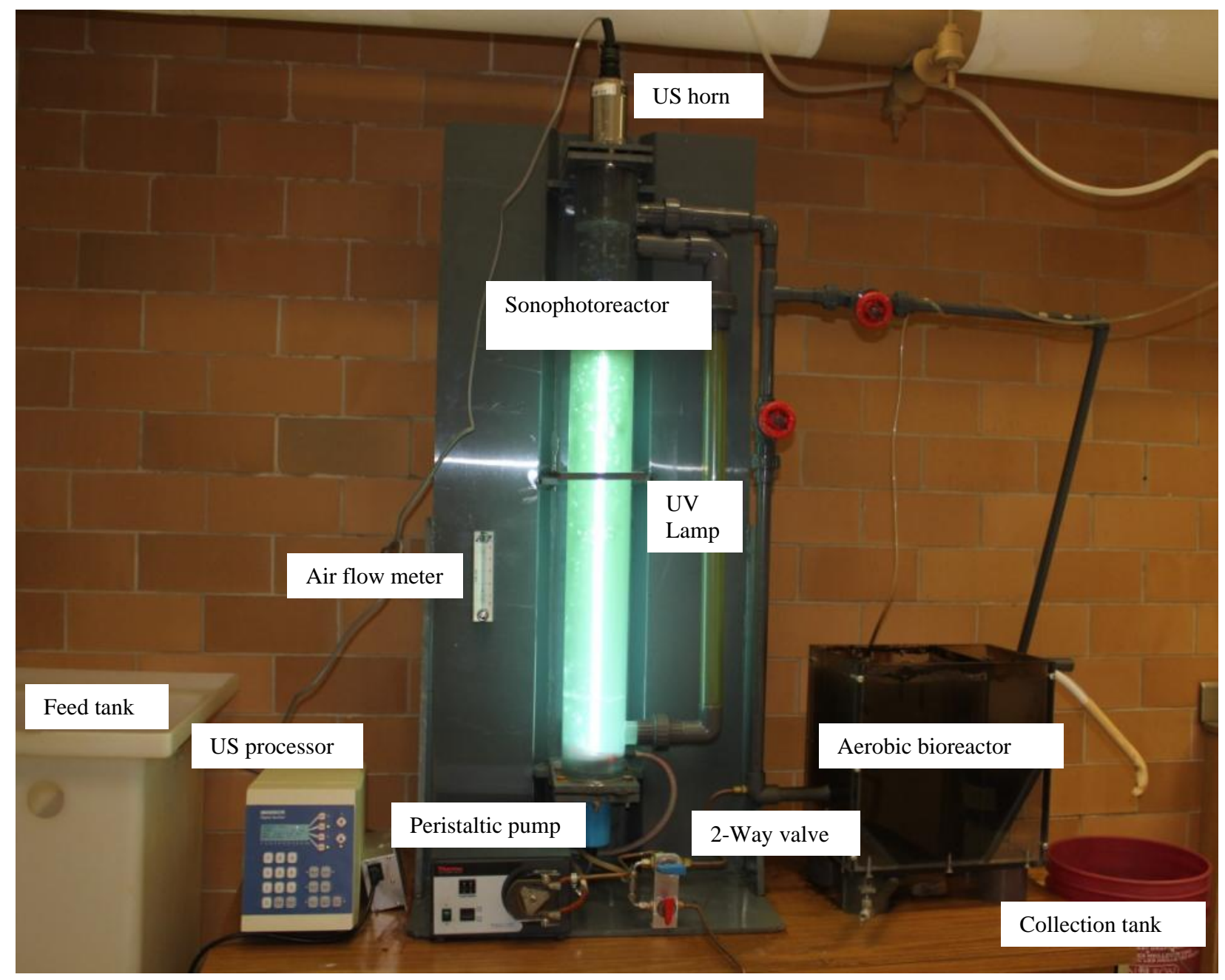

Figure 3.1. Laboratory view of the experimental setup for the combined $\mathrm{UV} / \mathrm{US} / \mathrm{H}_{2} \mathrm{O}_{2}$ and aerobic activated sludge processes. 


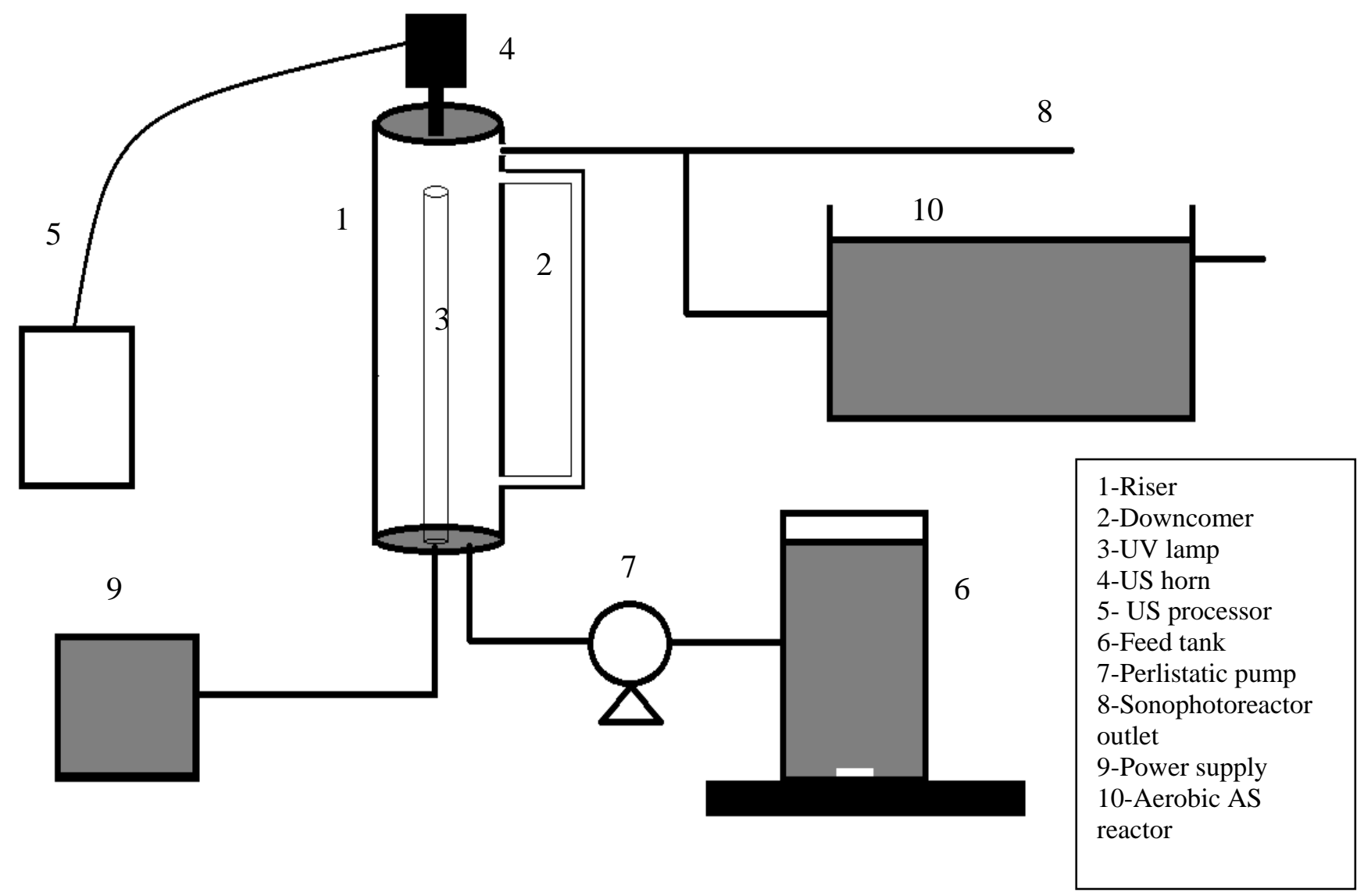

Figure 3.2. Schematic diagram of the experimental setup (sonophotoreactor and aerobic AS reactor) 


\subsection{Experimental Procedures}

\subsubsection{Acclimatization of the inoculum}

The objective of this experiment was to adopt the inoculum to the concentrations of the SPWW that used in this study. Eight liters of aerobic sludge seed was added into the aerobic AS reactor (Total volume: $25.5 \mathrm{~L}$ ) and then the reactor was filled with SPWW The inoculum with initial TSS of around $1750 \mathrm{mg} / \mathrm{L}$ was acclimatized by feeding the SPWW continuously into the reactor. The flow rate of the inlet SPWW for the acclimatization process was fixed at $20 \mathrm{~mL} / \mathrm{min}$. Acclimatization period performed for 30 days. This period can be divided into four periods of 7 days. The influent concentration of the SPWW to the reactor was increased gradually. In the first period ( $1^{\text {st }}$ day to $7^{\text {th }}$ day) the initial TOC of the raw SPWW was set to $22.5 \mathrm{mg} / \mathrm{L}$. Initial TOC increased to $45 \mathrm{mg} / \mathrm{L}, 90 \mathrm{mg} / \mathrm{L}$ and $180 \mathrm{mg} / \mathrm{L}$ on the $8^{\text {th }}, 15^{\text {th }}, 22^{\text {nd }}$ day, respectively. Nutrients were fed to the reactor as well to maintain the COD: N: P ratio of 100: 5: 1 (Sayadi et al., 2000). The nutrient medium consists of $\mathrm{KH}_{2} \mathrm{PO}_{4}, \mathrm{~K}_{2} \mathrm{HPO}_{4}, \mathrm{NaHPO}_{4} .7 \mathrm{H}_{2} \mathrm{O}, \mathrm{NH}_{4} \mathrm{Cl}, \mathrm{MgSO}_{4}, \mathrm{FeCl}_{3}$ and $\mathrm{CaCl}_{2}$ (Standard Methods, APHA, 1998). During the 30-days, samples were collected from the bioreactor to measure TSS (MLSS) and VSS (MLVSS). These parameters are used to determine the growth of microorganism and confirm acclimatization process. The experiments started after reaching the stabilization phase.

\subsubsection{Aerobic activated sludge process}

After the acclimatization process, the SPWW was treated in the aerobic AS reactor alone. Four different influent concentrations of the SPWW at various flow rates between 8.68 to 34.72 $\mathrm{mL} / \mathrm{min}$ were fed to the reactor. The hydraulic retention time (HRT) varied between 12 to $48 \mathrm{~h}$ 
which causes TOC loading rates of $0.93-15 \mathrm{mg} /(\mathrm{L} . \mathrm{h})$ and COD loading rates of 2.64-42.91 $\mathrm{mg} /(\mathrm{L} . \mathrm{h})$. The SPWW in the feed tank was continuously fed to the bioreactor using a peristaltic pump (Thermo scientific, US). The flow entered to the aerobic reactor using a 2-way valve. Air was introduced to the aeration tank of the reactor by a diffuser at a flow rate of $500 \mathrm{~mL} / \mathrm{min}$ followed by a clarifier. After treatment biologically, the effluent was collected in a storage tank. Samples were taken from both clarifier and the collection tank, filtered with 0.45 Micron filter paper (Whatman, $15 \mathrm{~cm}$ diameter) and analyzed for measuring their $\mathrm{pH}$, temperature, $\mathrm{BOD}_{5}$, TOC, TN, and COD. All the experiments were repeated for two times and reported results are the average of the obtained results.

\subsubsection{Photolytic, sonolytic, and sonophotolytic processes in batch and continuous modes}

Photolytic, sonolytic, and sonophotolytioc processes were used to treat the SPWW in both batch and continuous modes. Three pharmaceutical wastewater samples with influent TOC concentrations of $44.83,89.75$ and $179.33 \mathrm{mg} / \mathrm{l}$ were directed to the $\mathrm{AOP}$ reactor under various operating conditions.

The SPWW was made and homogenized through mixing by magnetic stirrer in the feed tank. Desired amount of $\mathrm{H}_{2} \mathrm{O}_{2}$ was added to the feed tank as well. When required, $\mathrm{pH}$ was adjusted by addition of $1 \mathrm{~N}$ solutions of $\mathrm{NaOH}$ or $\mathrm{H}_{2} \mathrm{SO}_{4}$. The sonophotoreactor was fed from the feed tank using the peristaltic pump. In batch mode experiments, every $30 \mathrm{~min}, 40 \mathrm{~mL}$ samples were taken from the reactor to determine their $\mathrm{pH}, \mathrm{TOC}, \mathrm{TN}$. All of the experiments were repeated for two times and reported results are the average of the obtained results. Also, two replicates were made for each analytical measurement. 
First experiments were performed without UV and US irradiations. These dark experiments carried out to evaluate the possible adsorption of components in the SSPW on the walls of the sonophotoreactor or their volatilization using $\mathrm{H}_{2} \mathrm{O}_{2}$ concentrations of $0,250,1000 \mathrm{mg} / \mathrm{L}$. In the next step, treatment ability of seven processes of $\mathrm{H}_{2} \mathrm{O}_{2}$ alone, photolysis (UV alone), sonolysis (US alone), UV/US, $\mathrm{UV} / \mathrm{H}_{2} \mathrm{O}_{2}, \mathrm{US} / \mathrm{H}_{2} \mathrm{O}_{2}$ and $\mathrm{US} / \mathrm{UV} / \mathrm{H}_{2} \mathrm{O}_{2}$ were compared of TOC removal in batch mode.

After preliminary tests, batch experiments were performed with initial $\mathrm{H}_{2} \mathrm{O}_{2}$ concentrations of 0 , 250, 500, 750, 1000, 1250, 1500, 1750, 2000, 2250, 2500, 2750 and $3000 \mathrm{mg} / \mathrm{L}$, SPWW with initial TOC concentrations of 44.83, 89.75 and $179.33 \mathrm{mg} / \mathrm{L}$, ultrasonic power of 20 to 140 Watt, initial $\mathrm{pH}$ of 2, 3.9, 6 and 8 and air flow rates of 1 to $5 \mathrm{~L} / \mathrm{min}$. Main objective of the experiments in batch mode was to determine the optimum operating parameters. Also optimum initial molar ratio of $\left[\mathrm{H}_{2} \mathrm{O}_{2}\right] /[$ TOC $]$ which is critical parameters in advanced oxidation processes was determined.

After determining the optimum condition in batch mode, the SPWW with initial TOC of 44.83 $\mathrm{mg} / \mathrm{L}$ was treated in continuous mode to investigate the performance of the airlift sonophotoreactor at various residence times of 30,60, 90, 120, 150, and $180 \mathrm{~min}$. The flow rates were in the range of 38.88 to $233.33 \mathrm{~mL} / \mathrm{min}$. In continuous mode, effluents of the AOP reactor were analyzed to determine their TOC, COD, TN, and BOD5. The residual concentration of $\mathrm{H}_{2} \mathrm{O}_{2}$ was also measured using 2,9-dimethyl-1,10-phenanthroline (DMP) method. Biodegradability of the samples was evaluated by studying $\mathrm{BOD}_{5} / \mathrm{COD}$ ratio and average oxidation state.

Based on the results from both batch and continuous modes, the operational parameters which should be used for combination of the UV/US/ $\mathrm{H}_{2} \mathrm{O}_{2}$ and aerobic AS processes were determined. 


\subsubsection{Combined UV/US/ $\mathrm{H}_{2} \mathrm{O}_{2}$ and aerobic AS processes}

After conducting experiments in the UV/US/ $\mathrm{H}_{2} \mathrm{O}_{2}$ process and the aerobic AS process separately and determining the optimal operating parameters, the combined process was applied to treat the SPWW. The two important factors which should be considered while combining the advanced oxidation and activated sludge processes are $\mathrm{BOD}_{5} / \mathrm{COD}$ ratio (or any parameters which reveals biodegradability) and concentration of $\mathrm{H}_{2} \mathrm{O}_{2}$ in the effluents from AOP reactor. The high concentration of the oxidant can inhibit the growth and activity of microorganisms in the following bioreactor.

In these experiments, the wastewater was prepared and fed to the sonophotoreactor continuously using a peristaltic pump (Thermo scientific, US). The UV/US/ $/ \mathrm{H}_{2} \mathrm{O}_{2}$ process was applied as the pre-treatment to increase the biodegradability of the SPWW. The effluent from the AOP reactor was collected for further treatment by biological method. The $\mathrm{pH}$ of the pretreated samples was adjusted to neutral $\mathrm{pH}$ using $1 \mathrm{~N} \mathrm{NaOH}$ solutions before introducing them to the aerobic AS reactor. Then, the pretreated wastewater was sent to the bioreactor for final treatment. Final discharge from the bioreactor was also analyzed to observe the efficacy of the combined treatment.

\subsection{Analytical Techniques}

In this study, several parameters such as temperature, TOC, TN, COD, DO, BOD $5, \mathrm{pH}$, TSS, and volatile suspended solid (VSS) of the SPWW and mixed liquor were measured according to the standard methods (APHA, 1998). In this section, the analytical techniques used to measure each parameter are explained. 


\subsubsection{Temperature and $\mathrm{pH}$}

The $\mathrm{pH}$ and temperature of the samples of the SPWW from inlet and outlet of the reactors were measured using a portable $\mathrm{pH}$ meter (Thermo Orion, Model 230A $\mathrm{A}^{+}$. In the instrument, indicator and reference electrodes are combined in one. It has a $\mathrm{pH}$ accuracy of \pm 0.02 , a temperature accuracy of $\pm 1^{\circ} \mathrm{C}$ and a temperature range of -5.0 to $105.0^{\circ} \mathrm{C}$. Calibration of the $\mathrm{pH}$ meter was performed using either $\mathrm{pH} 4.01$ and 7.00 buffer solutions or $\mathrm{pH} 7.00$ and 10.01 buffer solutions depending on the expected sample ranges.

\subsubsection{Dissolved oxygen (DO)}

Dissolved oxygen of influent and effluent samples of the synthetic pharmaceutical wastewater was measured by a dissolved oxygen meter (YSI 58 DO Meter) equipped with a BOD bottle probe (YSI 5905 BOD Probe). The instrument displayed DO in $\mathrm{mg} / \mathrm{L}(1 \mathrm{mg} / \mathrm{L}=1 \mathrm{ppm})$ or in percent air saturation. The membrane of the probe was replaced for each calibration. The probe was filled with electrolyte solution (Potassium iodide, $\mathrm{KI}$ ) and then the membrane was replaced and fixed over the probe avoiding any air bubbles using an "O" ring. The DO meter was calibrated before every test using air-saturated water, obtained by aerating water for at least 15 min at a constant temperature, using the calibration by temperature measurement function of the DO meter. 


\subsubsection{Mixed liquor suspended solid (MLSS), mixed liquor volatile suspended solid (MLVSS), Total suspended solid (TSS) and Volatile suspended solid}

(VSS)

MLSS and MLVSS of the aerobic activated sludge wastewater samples were measured to observe the growth of the microorganisms in the bioreactor. Additionally, TSS and VSS of the effluents from aerobic AS reactor were determined to measure the solids concentration which should be in the range mentioned in Table 2.4. In order to measure MLSS or TSS, aluminum weighing dishes and filter papers were dried for $1 \mathrm{~h}$ in an oven (Binder Oven, Model FED 53) at temperature of $105^{\circ} \mathrm{C}$. Then, $5 \mathrm{~mL}$ of mixed sludge samples from aeration tank of the bioreactor were filtered by weighed filter papers using a Buchner funnel connected to a vacuum system. The filter papers transferred to weighing dishes. The packages of sludge sample, filter paper and aluminum dish weighted and then brought to the oven and heated for $1 \mathrm{~h}$ in the temperature of $105{ }^{\circ} \mathrm{C}$. After cooling to room temperature in a dessicator, they were weighed again. In this step, TSS (or MLSS) could be obtained by following formula:

$\operatorname{TSS}$ or MLSS $=\frac{W_{3}-W_{2}-W_{1}}{V}$

where:

$W_{1}=$ Weight of dried aluminum dish (mg);

$W_{2}=$ Weight of dried filter paper $(\mathrm{mg})$

$W_{3}=$ Sum of weights of solids of the sample, aluminum dish and filter paper (mg); and $V=$ Volume of the sample (L); 
In order to measure VSS (or MLVSS), the packages of sludge sample, filter paper, and aluminum dish, after drying in oven, brought to a furnace (Thermo Scientific Lindberg® Blue M® Muffle Furnace) and burned at $550^{\circ} \mathrm{C}$ for $20 \mathrm{~min}$. After cooling in dessicator, they were weighed. MLVSS could be determined by equation 3.2 as following:

$$
V S S \text { or } M L V S S=\frac{\left(W_{3}-W_{2}-W_{1}\right)-\left(W_{4}-W_{1}\right)}{V}
$$

where:

$W_{4}=$ Sum of the weights of the solids of the sample, paper filter and aluminum dish after burning (mg).

\subsubsection{UV-vis spectrophotometer}

A UV spectrophotometer (Ultrospec 1100 pro UV-vis Spectrophotometer, Biochrom Ltd.) was used for the quantification of color in terms of absorbance. The instrument was able to measure absorbance, percent transmission, and concentration values. It can measure the absorbance of samples based on the amount of light passed through a sample relative to a blank. While percent transmission mode measures the amount of light that has passed through a sample relative to a blank, it displays the result as a percentage. The concentration mode can be used when a conversion factor is known, and it is essential to convert the absorbance measurement for a sample at a specific wavelength into a concentration. The wavelength of $454 \mathrm{~nm}$ was used for $\mathrm{H}_{2} \mathrm{O}_{2}$ measurements. The light sources are tungsten halogen for visible light and deuterium arc for ultraviolet light. The instrument has a one cell compartment. The detector was single solid state 
silicon photodiode. The cell was a standard rectangular quartz cell (optical glass). The cell has a volume of $5 \mathrm{~mL}$ and had a polytetrafluoroethylene (PTFE) cover.

\subsubsection{Chemical oxygen demand (COD) measurement}

COD test is a common used method which indirectly determines the amount of organic compounds in water. The test, measures the quantity of oxygen required to oxidize the organics in a solution by means of a powerful chemical oxidant.

Eckenfelder in 2000 mentioned two main drawbacks of this method as follows:

1. Some organics such as aromatics (e.g.: benzene) and volatile straight-chain aliphatic compounds are not get oxidized completely and are not accounted in COD test. Thus, the obtained COD underestimates the theoretical oxygen demand (ThOD).

2. Some reduced substances such as sulfides, sulfites, and ferrous ions are oxidized and accounted for COD. Therefore, they exert an oxygen demand and overestimate the ThOD.

Several methods have been proposed in the open literature for COD measurement (Zhao et al., 2004; Korenaga et al., 1993). In This study, The COD tests were carried out using the closed refluxed method since it is more economical for the range COD expected. The method is based on the oxidation of organics by a mixture of potassium dichromate $\left(\mathrm{K}_{2} \mathrm{Cr}_{2} \mathrm{O}_{7}\right)$ and sulphuric acid (Standard Methods, APHA, 1998). Potassium dichromate is a strong oxidizing agent under acidic conditions. The acidity usually provided by the addition of sulphuric acid. The reaction of potassium dichromate with organic compounds can be described as follows:

$\mathrm{C}_{n} \mathrm{H}_{a} \mathrm{O}_{b} \mathrm{~N}_{c}+d \mathrm{Cr}_{2} \mathrm{O}_{7}^{2-}+(8 d+c) \mathrm{H}^{+} \rightarrow n \mathrm{CO}_{2}+\left(\frac{a+3 d-3 c}{2}\right) \mathrm{H}_{2} \mathrm{O}+c \mathrm{NH}_{4}^{+}+2 d \mathrm{Cr}^{3+}$ 
Where:

$d=\frac{2 n}{3}+\frac{a}{6}-\frac{b}{3}-\frac{c}{2}$

In the oxidizing process of organic compounds, as shown in Reaction (3.3), potassium dichromate is reduced and forms $\mathrm{Cr}^{3+}$. After completion of the oxidizing process, the amount of $\mathrm{Cr}^{3+}$ is measured and is used as an indirect measure of the organic content of the samples.

In colorimetric method (closed reflux), oxygen consumption is measured against standards at 600 nm with a multi-parameter Colorimeter (MC500, Orbeco). The reagent vials for COD measurements were purchased from Bioscience Inc. in the range of 20-900 mg/L. Vials contained sulfuric acid, potassium dichromate, silver sulfate as catalyst, mercuric sulfate and sulfamic acid. The COD reactor (Bioscience, Inc.) was preheated to $150 \pm 2^{\circ} \mathrm{C}$ prior to preparation of the vials. Each vial has a volume of $10 \mathrm{~mL}$. The reagent vials were uncapped and $2 \mathrm{~mL}$ of sample solution (for $2-900 \mathrm{mg} / \mathrm{L}$ range vials) was carefully added from the side of the vial. The sample produced a layer on top of the reagents. Therefore, the vial was shaken manually to mix well. Blank samples (distilled water) were processed exactly the same as the samples. COD vials containing samples and blank were heated in the COD reactor for $2 \mathrm{hr}$ at $150 \pm 2^{\circ} \mathrm{C}$ for complete reaction. After $2 \mathrm{~h}$, they were removed from the reactor and were placed in a rack until they are cooled to room temperature and any suspended precipitate in the vials was settled. Then, the vials were placed in colorimeter. First, the vial with blank sample was placed in the colorimeter to calibrate the instrument. Then, each sample was measured in triplicate and their average value was reported as the COD reading in $\mathrm{mg} / \mathrm{L}$.

Each sample's result was displayed as it was collected. The COD removal efficiency was determined by Equation (3.4) as follows: 


$$
C O D=\frac{\left(C O D_{\text {in }}-C O D_{\text {out }}\right)}{C O D_{\text {in }}} \times 100 \%
$$

where:

$\mathrm{COD}$ in : COD concentration of influent wastewater sample, $\mathrm{mg} / L$; and COD out: COD concentration of effluent wastewater sample, $\mathrm{mg} / L$.

\subsubsection{Hydrogen peroxide measurement}

Presence of residual $\mathrm{H}_{2} \mathrm{O}_{2}$ can interfere with $\mathrm{COD}$ measurements, since it can react with dichromate. Also, $\mathrm{H}_{2} \mathrm{O}_{2}$ is known as an inhibitor for bacterial growth and activity. Therefore, residual $\mathrm{H}_{2} \mathrm{O}_{2}$ can prevent bacterial growth in $\mathrm{BOD}_{5}$ test and hence underestimate actual BOD. Removal or minimizing of $\mathrm{H}_{2} \mathrm{O}_{2}$ is important especially, in the case of BOD measurement or biological treatment step which is fed from effluent of the sonophotoreactor.

The $\mathrm{H}_{2} \mathrm{O}_{2}$ was measured using DMP method as described in a study by Kosaka et al. (1988). The method has a detection limit of $0.8 \mu \mathrm{M}$. The procedure of DMP method is based on the reduction of copper (II) with $\mathrm{H}_{2} \mathrm{O}_{2}$ through following reaction:

$\mathrm{Cu}^{2+}+4 \mathrm{DMP}+\mathrm{H}_{2} \mathrm{O}_{2} \rightarrow 2 \mathrm{Cu}(\mathrm{DMP})_{2}^{+}+\mathrm{O}_{2}+2 \mathrm{H}^{+}$

$\mathrm{Cu}(\mathrm{DMP})_{2}{ }^{+}$is a stable bright yellow complex which has its maximum absorbance at wavelength of $454 \mathrm{~nm}$. In order to use DMP method, three reagents should be prepared in advance. First solution is prepared by dissolving one gram of DMP (2, 9-dimethyl-1, 10-phenathroline) (Alfa Aesar, Heysham, United Kingdom) in $100 \mathrm{~mL}$ of ethanol. The solution should be stored in a dark bottle in $4^{\circ} \mathrm{C}$. A $0.01 \mathrm{M}$ of copper (II) sulphate solution was made by dissolving copper (II) in water. Finally, $13.5 \mathrm{~g} \mathrm{~K}_{2} \mathrm{HPO}_{4}$ and $12 \mathrm{~g} \mathrm{NaH}_{2} \mathrm{PO}_{4}$ were dissolved in distilled water to produce a $0.1 \mathrm{M}$ phosphate buffer solution. The $\mathrm{pH}$ of the third solution should be adjusted to 7 .

After preparation of the reagents following steps should be pursued: 
1. One $\mathrm{mL}$ of each reagent described above was added to a $10 \mathrm{~mL}$ volumetric flask and mixed well.

2. Three $\mathrm{mL}$ of the sample, whose $\mathrm{H}_{2} \mathrm{O}_{2}$ concentration is desired, was added to the flask and diluted with distilled water to $10 \mathrm{~mL}$.

3. After appropriate mixing, the absorbance of the sample was measured at 454 using the UV spectrophotometer described in Section 3.6.4.

4. Blank solutions were prepared in the same way but distilled water used instead of sample.

5. A calibration curves were prepared using different standards with various concentrations of $\mathrm{H}_{2} \mathrm{O}_{2}$ and determining their absorbance at $454 \mathrm{~nm}$.

6. After preparing the calibration curve, $5 \mathrm{~mL}$ of the sample solution in volumetric flask were poured in the cell of the spectrophotometer and the cell was put in the instrument carefully.

7. Using the calibration curves, concentration of the samples could be found comparing the absorbance of the samples with standard solutions.

A calibration curve for range for hydrogen peroxide measurement is shown in Figures 3.3. 


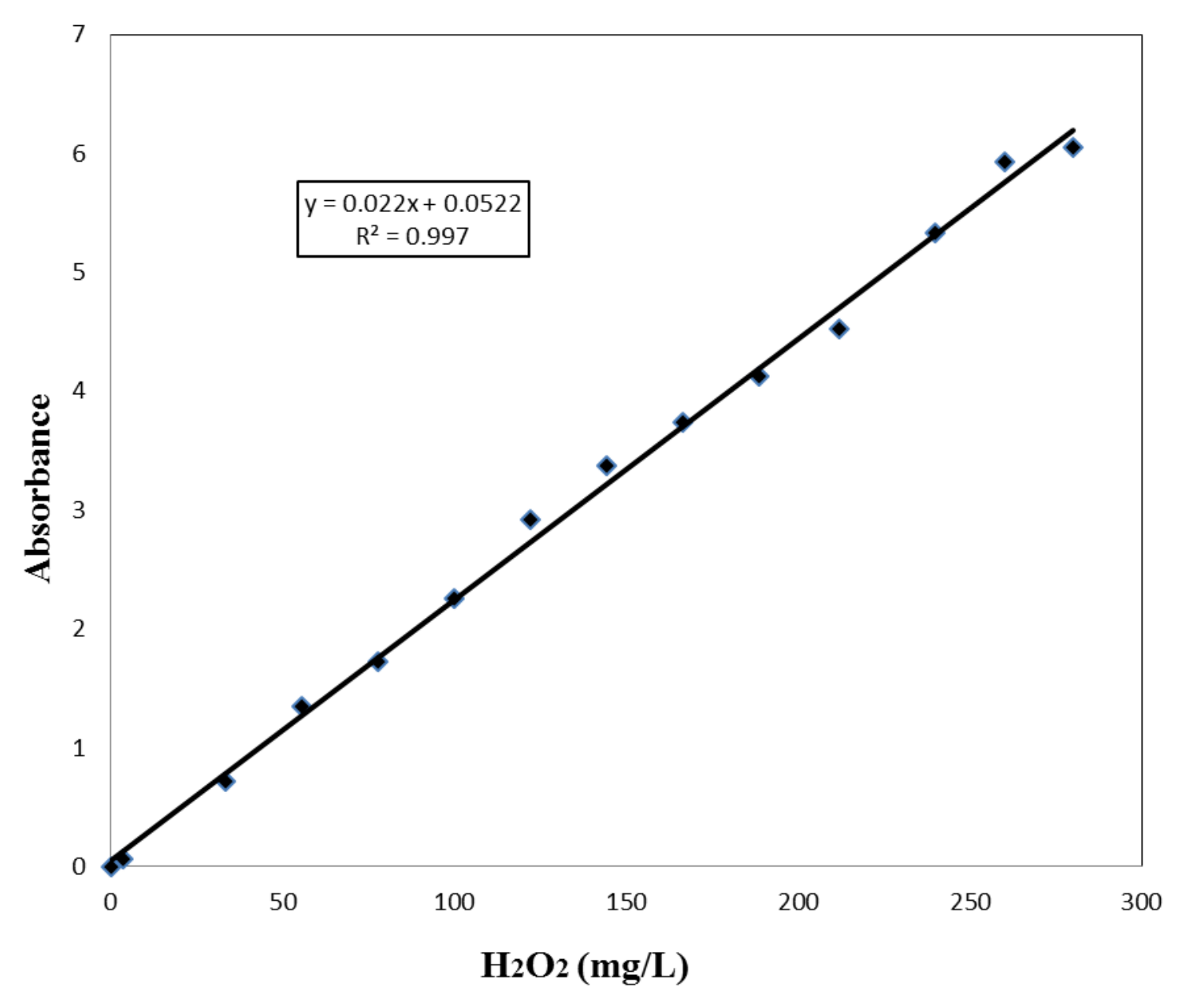

Figure 3.3. Calibration curve of $\mathrm{H}_{2} \mathrm{O}_{2}$ concentration measurement based on DMP method. 


\subsubsection{Total organic carbon (TOC) and total nitrogen (TN)}

The TOC is one of the most important parameters in assessment of organic pollution in of water. Since it includes all carbon compounds as one mass, it is exactly defined as an absolute quantity. Therefore, it can be determined directly. The TOC analyzer subtracts the inorganic carbon (such as $\mathrm{CO}$ and $\mathrm{CO}_{2}$ ) and reports the total organic carbon, which is a close estimate of organic content. The main difference between TOC analyzers are in the methods used for oxidation and $\mathrm{CO}_{2}$ quantification. Combustion and wet chemistry are two examples of oxidation methods. The oxidation step can be carried out at high or low temperatures. It is known that analyzers which use combustion (high temperature oxidation) provide more complete oxidation of carbon compounds than other analyzers.

For determination of TOC, two main of methods exist. The first one is called differential method and TOC is calculated by subtracting IC (inorganic carbon) from TC (total carbon). TC and IC should be found separately. However, in the second method, IC is removed from a sample by purging the acidified sample with a purified gas, and while getting rid of IC, TOC is equal to TC. This method is named direct or NPOC (non-purgeable organic carbon), since POCs (purgeable organic carbon) such as benzene, toluene and cyclohexane may be removed partially from a sample through gas stripping (Mohajerani, 2012).

Total Nitrogen $(\mathrm{TN})$ is the sum of nitrate-nitrogen $\left(\mathrm{NO}_{3}-\mathrm{N}\right)$, nitrite-nitrogen $\left(\mathrm{NO}_{2}-\mathrm{N}\right)$, ammonianitrogen $\left(\mathrm{NH}_{3}-\mathrm{N}\right)$ and organically bonded nitrogen. Total Nitrogen $(\mathrm{TN})$ is different from TKN (total kjeldahl nitrogen). TKN is the sum of ammonia-nitrogen $\left(\mathrm{NH}_{3}-\mathrm{N}\right)$ and organically bound nitrogen but does not include nitrate-nitrogen or nitrite-nitrogen. TN is sometimes regulated as an effluent parameter for municipal and industrial wastewater treatment plants, but it is more common for limits to be placed on an individual nitrogen form, such as ammonia. 
In this study, TOC and TN were measured using a Teledyne Tekmar Apollo 9000 Combustion TOC/TN Analyzer equipped with an automated sampler. In order to obtain calibration curves, standards were prepared by addition of a carbon source or a nitrogen source to distilled water to achieve determined levels of carbon or nitrogen. The procedures to prepare reagent solutions are as follow:

1. For TOC calibration curve, potassium hydrogen phthalate (KHP) was used as the organic carbon source. The KHP was dried in an oven at $105^{\circ} \mathrm{C}$ for $2 \mathrm{~h}$ and stored in a desiccator in order to cool to the room temperature and to remove any absorbed moisture from the atmosphere. The calibration curve was performed via preparing a set of standard solutions within the expected range of sample concentrations, namely 1-400 $\mathrm{mg} / \mathrm{L}$. In order to prepare $1000 \mathrm{mg} / \mathrm{L}$ of KHP stock solution, 2,125 mg of KHP was dissolved in $1 \mathrm{~L}$ of distilled water. Other standard solutions of 1, 25, 50, 100, 250 and 400 were prepared by diluting the stock solution carefully. Through running the TOC standard calibration analysis, a calibration curve was obtained in the range of $1-400 \mathrm{mg} / \mathrm{L}$ and it is shown in Figure 3.4. TOC removal efficiency was calculated using Equation 3.5.

$$
T O C=\frac{T O C_{i n}-T O C_{o u t}}{T O C_{i n}} \times 100 \%
$$

Where,

TOC in = TOC concentration of the influent wastewater $(\mathrm{mg} / \mathrm{L})$; and

TOC out $=$ TOC concentration of the effluent wastewater $(\mathrm{mg} / \mathrm{L})$.

2. For $\mathrm{TN}$ calibration curve potassium nitrate $\left(\mathrm{KNO}_{3}\right)$ was used as nitrogen source. The $\mathrm{KNO}_{3}$ was dried in an oven at $80^{\circ} \mathrm{C}$ for $1 \mathrm{~h}$ and then cooled in a desiccator. A $1000 \mathrm{mg} / \mathrm{L}$ 
stock standard solution was prepared by dissolving $7.22 \mathrm{~g}$ of $\mathrm{KNO}_{3}$ in $1 \mathrm{~L}$ distilled water. Similar to TOC, a set of working standard solutions covering the expected range of sample concentrations $(1-20 \mathrm{mg} / \mathrm{L})$ were prepared by diluting the stock solution with distilled water cautiously. TN standard solutions were analyzed and a TN calibration curve was obtained in the mentioned range as shown in Figure 3.5. 


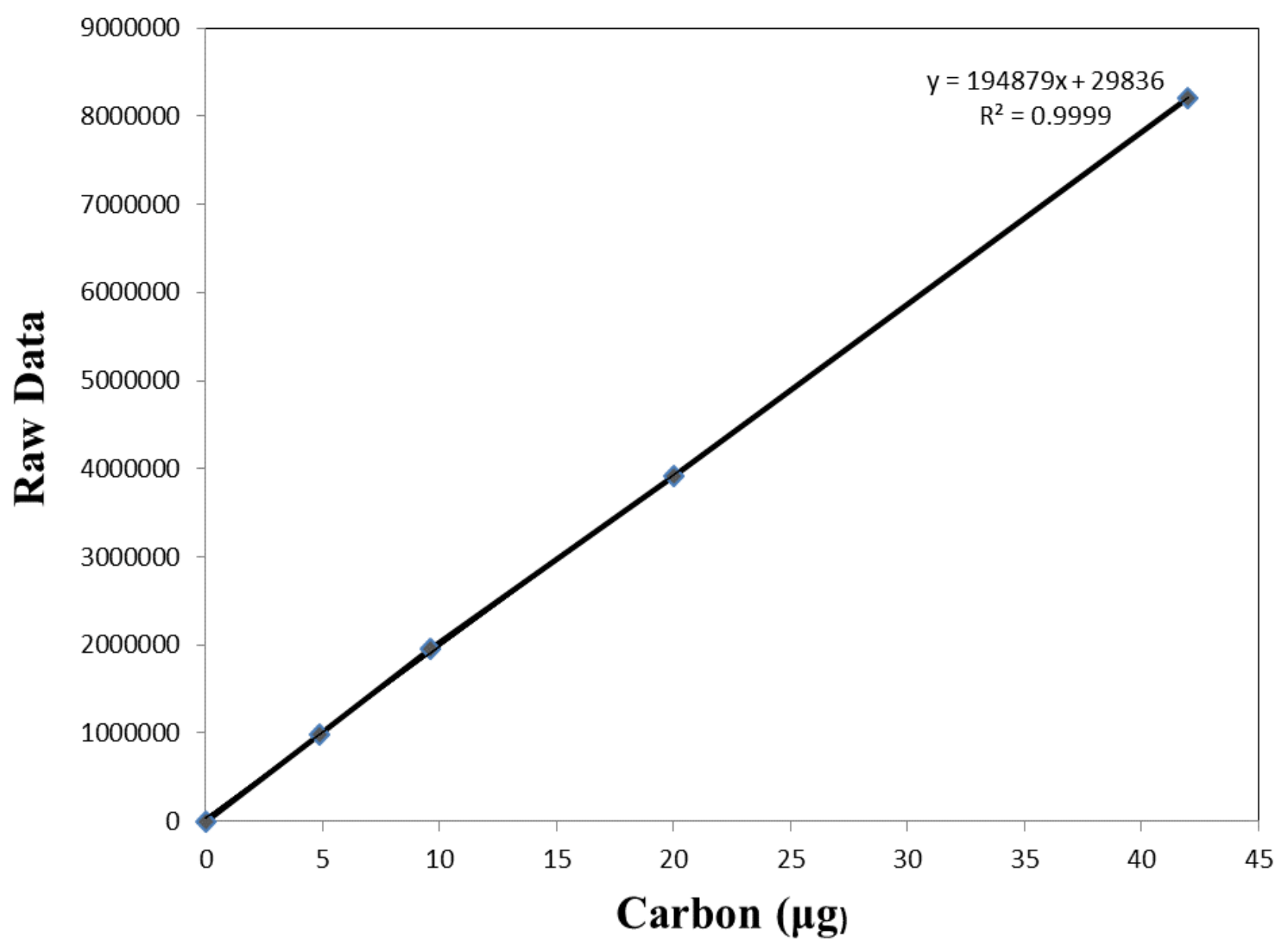

Figure 3.4. TOC calibration curve for the range of $1-400 \mathrm{mgTOC} / \mathrm{L}$. 


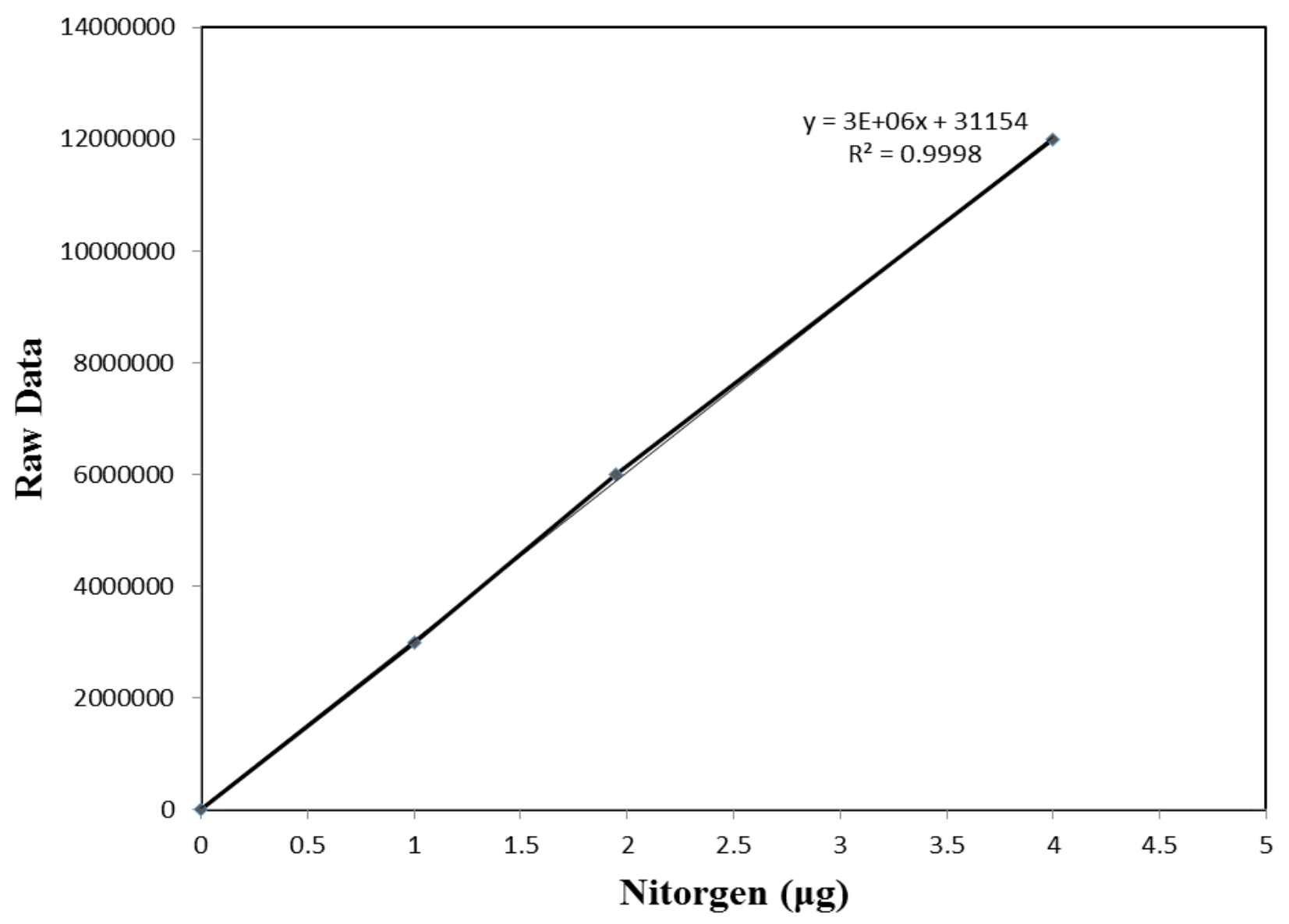

Figure 3.5. TN calibration curve for the range of 1-20 mgTN/L. 


\subsubsection{Respirometer}

Respirometers are devices which measure respiration of living organisms. Respirometers have been employed to monitor the metabolic reactions of microorganisms in aqueous media. Respirometric experiments were performed using a BI-2000 electrolytic respirometer (Bioscience Inc., Bethlehem, Pennsylvania) in order to observe the biodegradability of the untreated and pretreated wastewater samples and measuring their BOD5. The respirometer has eight $1 \mathrm{~L}$ bioreactor vessels which were prepared according to the standard methods. Each respirometer bioreactor was loaded with the required amount of acclimatized activated sludge $(10 \mathrm{~mL}$, according to instrument guidebook), $10 \mathrm{~mL}$ of the wastewater sample and filled up to $1 \mathrm{~L}$ with distilled water. Continuous aeration to obtain air saturation conditions and continuous agitation were applied on the bioreactors. Respirometer tests were carried out for $120 \mathrm{~h}$ (5-days) or more while required at $25^{\circ} \mathrm{C}$ at an oxygen generation rate of $75 \mathrm{mg} / \mathrm{L}$. Cumulative oxygen uptake data were recorded every $0.05 \mathrm{~h}$. The data was seen on the computer which was connected to the instrument. Two control samples, untreated solution and sludge, were used as control (Mohajerani, 2012). 


\section{CHAPTER 4 \\ RESULTS AND DISCUSSION}

\subsection{Introduction}

In this chapter, the results obtained during the experimental work, the characteristics of the SPWW, the performance and the treatment ability of the aerobic AS, photolysis $\left(\mathrm{UV} / \mathrm{H}_{2} \mathrm{O}_{2}\right)$ and sonophotolysis $\left(\mathrm{UV} / \mathrm{US} / \mathrm{H}_{2} \mathrm{O}_{2}\right)$ processes, as well as their combination for the removal of TOC, COD and BOD from SPWW are presented. Additionally, a comprehensive discussion regarding the optimum operating parameters, such as $\mathrm{H}_{2} \mathrm{O}_{2}$ dosage and the molar ratio of $\left[\mathrm{H}_{2} \mathrm{O}_{2}\right] /$ [TOC], $\mathrm{pH}$, air flow rate, US output power, initial TOC load of the SPWW, and hydraulic retention time is provided. Furthermore, some studies have been done on evolution of $\mathrm{H}_{2} \mathrm{O}_{2}$ concentration during sonophotolysis processes, which are described later in this chapter.

\subsection{Characteristics of the SPWW}

Three different synthetic pharmaceutical wastewater samples were employed in the present study. In this section, the main characteristics of the wastewater samples, such as temperature, $\mathrm{pH}$, TSS, and VSS, are presented. 


\subsubsection{Reynolds number}

Due to the size of the reactors, in all processes including aerobic activated sludge, photolysis and sonophotolysis, the calculated Reynolds number was much less than 2100. Consequently, all the experiments were done in the laminar flow regime. The calculation of Reynolds number for all the experiments is shown in Appendix C.

\subsubsection{Temperature and $\mathrm{pH}$}

The initial $\mathrm{pH}$ of the SPWW was in the range of 3.8 to 4.0. Before introducing the SPWW to the bioreactor, $\mathrm{pH}$ was increased to neutral $\mathrm{pH}$ of 7 , using $\mathrm{NaOH}$ solution, which is the ideal range for the growth of microorganisms (Antouniou et al., 1990). During the acclimatization of the biomass, $\mathrm{pH}$ values in the biological reactor were fluctuating significantly. This may be attributed to metabolism and enzyme reactions during the growth of the microorganisms. The $\mathrm{pH}$ values in the aerobic AS aeration tank were in the range of 5.53 to 7.81 .

On the other hand, while conducting experiments, $\mathrm{pH}$ values in the aeration tank varied between 6.82 and 6.95. Moreover, in the combined processes, the $\mathrm{pH}$ of the effluents from the sonophotoreactor was adjusted to 7-7.5.

In the case of temperature, the initial temperature of the SPWW was in the range of 24.8 to $25.3^{\circ} \mathrm{C}$. However, effluents of the sonophotoreactor had temperature increase up to $33^{\circ} \mathrm{C}$.

For the activated sludge reactor, during both acclimatization period and experiments temperature varied between 24.5 and $25.6^{\circ} \mathrm{C}$. In the literature, the ideal temperature range for microbial growth has reported to be between 15 and $25^{\circ} \mathrm{C}$ (Antouniou et al., 1990; Tizghadam et al., 2008). 


\subsubsection{MLSS and MLVSS concentration of the aerobic activated sludge}

MLSS and MLVSS concentrations in the aerobic AS reactor are shown in Figures 4.1 respectively. Figure 4.1 shows that there is a quick rate of adoption of the microorganisms to the conditions inside the aeration tank. As mentioned in Chapter 3, during the acclimatization period, the wastewater concentration was increased gradually (initial TOC values of 22.5, 44.83, 89.75 and $179.33 \mathrm{mg} / \mathrm{L}$ ) for a period of 30 days. The presented trend in the Figures indicates a rapid growth of microorganism until reaching a plateau which is the stabilization phase. Also, the evolution of MLSS and MLVSS shows a successful acclimatization process. After 30 days of acclimatization, considerable amount of sludge was produced, and experiments were accomplished using MLSS and MLVSS of approximately 3,200 and 2,300 mg/L, respectively. As shown in Figure 4.1 the experiments were started after the reaching a steady state phase in growth curve of microorgansims. The results are in accordance with previous studies (Bustillo-Lecompte et al., 2013; Cao and Mehrvar, 2011). 


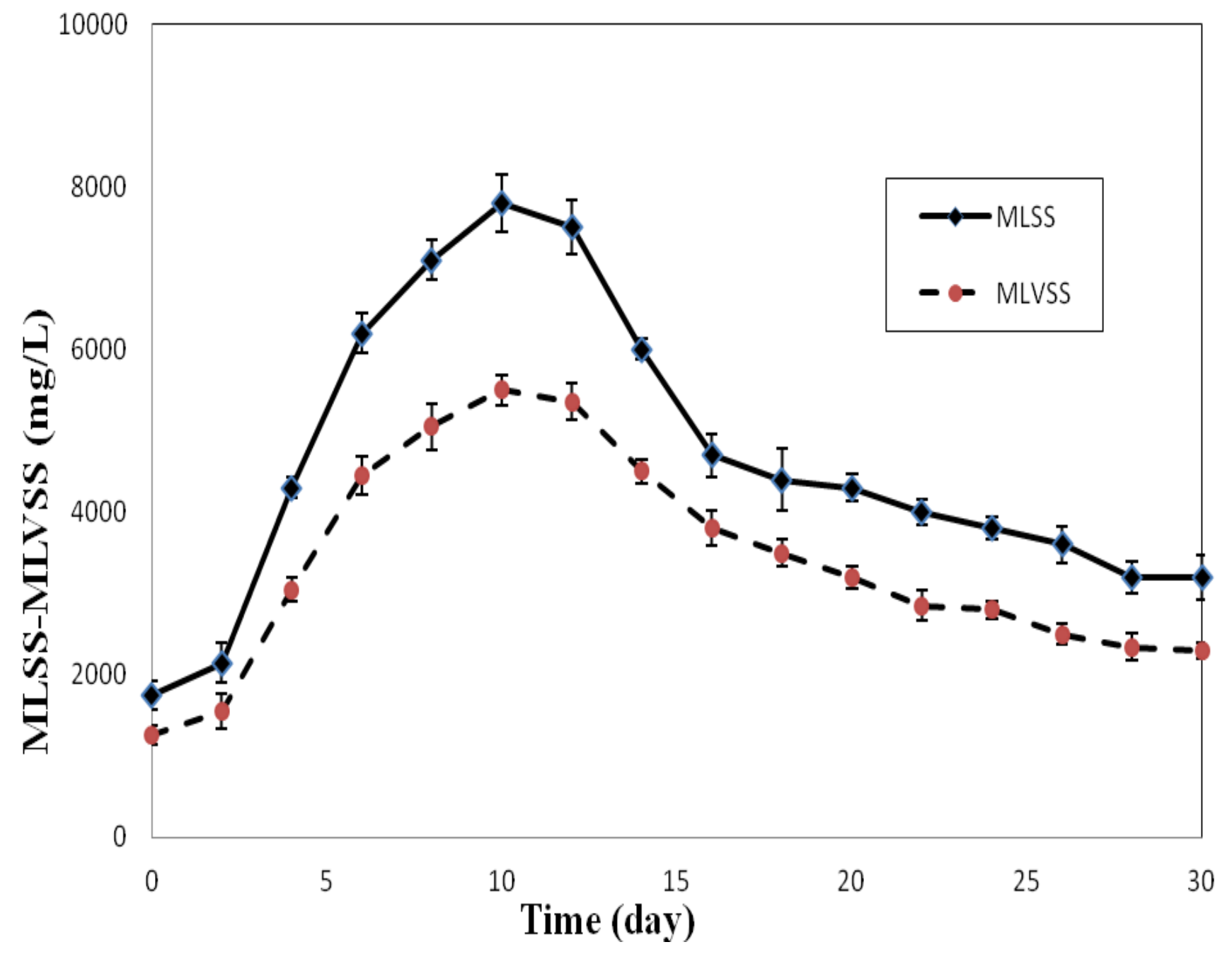

Figure 4.1. Evolution of MLSS and MLVSS for the aerobic AS process. 


\subsubsection{TSS and VSS concentrations of the SPWW}

During the aerobic AS process, four flow rates of the SPWW including 8.68, 11.57, 17.72, and $34.72 \mathrm{~mL} / \mathrm{min}$ were used. It was observed that by increasing the flow rate, the amount of TSS was increased. The TSS of the effluents of the aerobic biological reactor is shown in Table 4.1. According to the Canadian standard regulation for effluent discharge to lakes, rivers and shorelines, TSS should be less than $30 \mathrm{mg} / \mathrm{L}$ (Environment Canada, 2010). As shown in Table 4.1, increasing the flow rate to $34.72 \mathrm{~mL} / \mathrm{min}$ causes TSS reaches to $32 \mathrm{mg} / \mathrm{L}$, which is more than the allowed limit. For this reason, during combination of sonophotolysis and aerobic AS processes, the lower flow rates were applied.

Table 4.1.TSS and VSS profiles in the aerobic AS reactor.

\begin{tabular}{c|c|cc}
\hline Flow rate (mL/min) & TSS of SPWW in aerobic AS reactor & VSS of SPWW in aerobic AS \\
& $(\mathbf{m g} / \mathbf{L})$ & reactor $(\mathbf{m g} / \mathbf{L})$ \\
\hline 8.68 & 13 & 11 \\
11.57 & 18 & 15 \\
17.36 & 23 & 20 \\
34.72 & 32 & 26 \\
\hline
\end{tabular}




\subsection{TOC Removal in SPWW Using UV/US/ $/ \mathrm{H}_{2} \mathrm{O}_{2}$ Process Alone in}

\section{Batch Recirculation Mode}

In this section, efficiency of the $\mathrm{UV} / \mathrm{US} / \mathrm{H}_{2} \mathrm{O}_{2}$ process for the treatment of the SPWW is discussed in batch mode. The initial TOC and COD loading of the wastewater samples were in the range of 44.83-179.33 $\mathrm{mg} / \mathrm{L}$ and $127-515 \mathrm{mg} / \mathrm{L}$, respectively. In the first step, some preliminary experiments were conducted to evaluate the effectiveness of seven processes of $\mathrm{H}_{2} \mathrm{O}_{2}$ alone, sonolysis (US alone), photolysis (UV alone), UV/US, $\mathrm{UV} / \mathrm{H}_{2} \mathrm{O}_{2}, \mathrm{US} / \mathrm{H}_{2} \mathrm{O}_{2}$, and $\mathrm{UV} / \mathrm{US} / \mathrm{H}_{2} \mathrm{O}_{2}$ in TOC reduction of the SPWW. In the second step, the effect of various operating conditions such as initial $\mathrm{H}_{2} \mathrm{O}_{2}$ dosage, $\mathrm{pH}$, air flow rate, US power, and initial TOC load of the wastewater on the $\mathrm{UV} / \mathrm{US} / \mathrm{H}_{2} \mathrm{O}_{2}$ process was investigated in batch recirculation mode and results are discussed in details. There was no analysis of the intermediate components which might form during the $\mathrm{UV} / \mathrm{US} / \mathrm{H}_{2} \mathrm{O}_{2}$ process. In all the experiments temperature was in the range of 24.8 to $33^{\circ} \mathrm{C}$.

\subsubsection{Preliminary Studies}

The preliminary studies were performed by applying seven different processes including $\mathrm{H}_{2} \mathrm{O}_{2}$ alone, sonolysis (US alone), photolysis (UV alone), UV/US, UV/ $\mathrm{H}_{2} \mathrm{O}_{2}, \quad \mathrm{US} / \mathrm{H}_{2} \mathrm{O}_{2}$, and $\mathrm{UV} / \mathrm{US} / \mathrm{H}_{2} \mathrm{O}_{2}$ to the SPWW with initial TOC of $89.75 \mathrm{mg} / \mathrm{L}$ in batch recirculation mode. The effectiveness of the processes was compared based on TOC removal. Figure 4.3 depicts the performance of various processes in deducing the TOC of the wastewater.

As it can be seen from Figure 4.2, the degradation through the process of $\mathrm{H}_{2} \mathrm{O}_{2}$ alone was marginal. Only about $1.2 \%$ TOC reduction was observed after 150 min treatment time. The same 
results were reported by Arslan and Balcioglu (2001). They mentioned that there was not any degradation in the treatment of dye house effluent using $\mathrm{H}_{2} \mathrm{O}_{2}$ alone.

Sonolysis was also not effective in TOC removal. Using output power of $100 \mathrm{~W}$, only $4 \%$ reduction in TOC was observed.

Mohajerani, (2012) also reported negligible TOC removal during sonolysis in a wastewater samples containing sulfadiazine. They mentioned that this low efficiency may be due to high solubility and low volatility of water which make $\mathrm{H}_{2} \mathrm{O}_{2}$ molecules to be present in bulk solution rather than in cavitation bubbles. In another study (Jagannathana et al., 2013), sonolysis was able to drop TOC only by $12 \%$ in a solution containing paracetamol. On the other hand, some studies stated considerable degradation through sonolysis. Sivakumar and Muthukumar (2011) achieved $41 \%$ COD removal in 60 min sonolysis for a pharmaceutical wastewater sample. Saghafinia et al. (2011) obtained up to $65 \%$ of penicillin $\mathrm{G}$ concentration reduction during sonolysis after $50 \mathrm{~min}$ treatment. Some other studies with similar results could be also found in the open literature (Wu et al., 2001; Isariebel et al., 2009; Guyer and Ince, 2011).

The addition of $\mathrm{H}_{2} \mathrm{O}_{2}$ to the sonolysis process increased TOC removal by about $2 \%$. This may be due to the breakage of O-O bonds by US waves in the $\mathrm{H}_{2} \mathrm{O}_{2}$ structure, which causes the formation of hydroxyl radicals. Voncina and Marechal (2003) reported that the addition of $\mathrm{H}_{2} \mathrm{O}_{2}$ to US process enhances the rate of decolorization of dye solutions by two times. Phenol degradation also has been reported to improve in the $\mathrm{US} / \mathrm{H}_{2} \mathrm{O}_{2}$ process comparing with the US process alone (Entezari et al., 2003).

The photolytic process provided higher TOC removal than sonolysis. About $8 \%$ reduction in TOC was observed which is again not satisfactory. Direct UV treatment was also not effective enough in the elimination of pharmaceutical components such as diclofenac and carbamazepine from 
water (Vonga et al., 2004; Pereira et al., 2007). According to the study of Xu et al. (2013), it is most probable that low UV fluence causes this poor degradation. They observed an improvement in the degradation rate of dimethyl phthalate while increasing the UV light intensity.

Combining UV and US did not enhance degradation. The TOC reduction after 150 min of the US/UV process was $5 \%$ which is lower than that of photolysis and the $\mathrm{US} / \mathrm{H}_{2} \mathrm{O}_{2}$ processes. It has been proved that US irradiation produces $\mathrm{H}_{2} \mathrm{O}_{2}$ in aqueous solutions, which can be consequently converted to hydroxyl radicals under UV light (Hua and Hoffman, 1997). According to minor treatment, it seems that produced $\mathrm{H}_{2} \mathrm{O}_{2}$ was not sufficient. Some studies, however, mentioned positive synergic effect while combining US and UV. Na et al. (2012) observed $20 \%$ more TOC removal in US/UV process than that of UV alone during degradation of diethyl phthalate. Similar results were found by Khokhawala and Gogate (2010) in the case of phenol degradation. The difference in reported results can be explained by considering the nature of components being studied. The degradation of multicomponent wastewater is more difficult than single component degradation mainly due to interactions between components and formed intermediates. Also, the output power of the US instrument and power of the UV light can be influential in the degradation efficiency.

Photolysis in the presence of $\mathrm{H}_{2} \mathrm{O}_{2}$ provides more than 50\% TOC removal. Production of reactive radicals such as hydroxyl radicals that were formed during decomposition of $\mathrm{H}_{2} \mathrm{O}_{2}$ under UV light enhanced the treatability of the $\mathrm{UV} / \mathrm{H}_{2} \mathrm{O}_{2}$ process. Barrera (2011) also observed that the TOC removal was increased by addition of hydrogen peroxide to both VUV and UVA processes. 


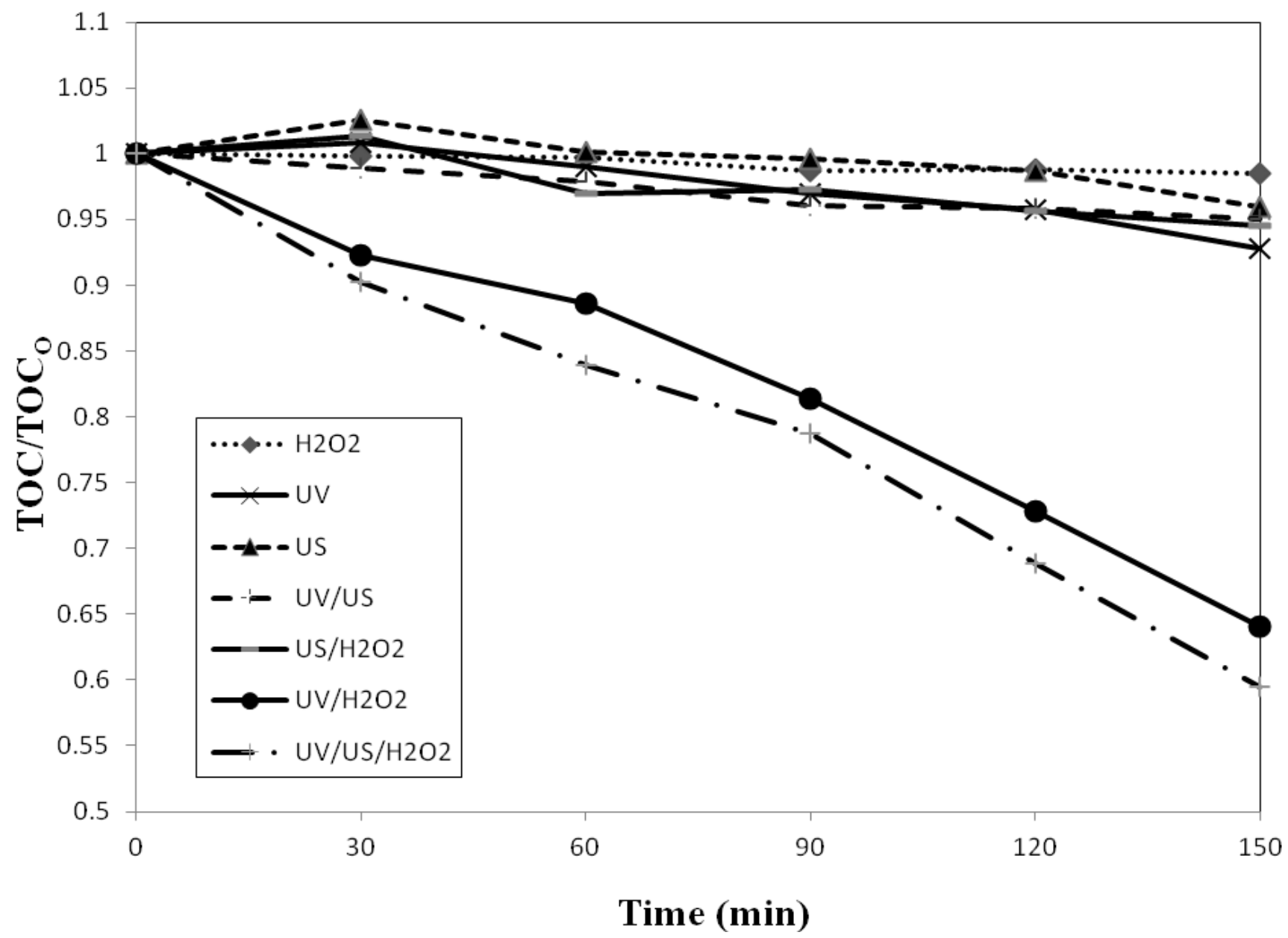

Figure 4.2. TOC reduction under batch mode $\mathrm{H}_{2} \mathrm{O}_{2}, \mathrm{UV}, \mathrm{US}, \mathrm{UV} / \mathrm{US}, \mathrm{US} / \mathrm{H}_{2} \mathrm{O}_{2}, \mathrm{UV} / \mathrm{H}_{2} \mathrm{O}_{2}$, and $\mathrm{UV} / \mathrm{US} / \mathrm{H}_{2} \mathrm{O}_{2}$ processes $\left([\mathrm{TOC}]_{0}=89.67 \mathrm{mg} / \mathrm{L},\left[\mathrm{H}_{2} \mathrm{O}_{2}\right]_{0}=1500 \mathrm{mg} / \mathrm{L}, \mathrm{US}\right.$ power $=100 \mathrm{~W}$, $\mathrm{pH}=3.9$ and airflow $=2 \mathrm{~L} / \mathrm{min}$ ). 
Finally, the highest TOC removal (38\%) was achieved during the sonophotolysis (UV/ $\left.\mathrm{US} / \mathrm{H}_{2} \mathrm{O}_{2}\right)$ process. Intensified generation of the radicals due to the UV/US/ $\mathrm{H}_{2} \mathrm{O}_{2}$ process is the main explanation of high treatment efficiency. Furthermore, extra turbulence caused by the microstreaming effect of the ultrasonic wave supplied better solution mixing and enhanced degradation.

\subsubsection{Optimum operating conditions for $\mathrm{UV} / \mathrm{US} / \mathrm{H}_{2} \mathrm{O}_{2}$ process}

\subsubsection{Optimal $\mathrm{H}_{2} \mathrm{O}_{2}$ dosage for the $\mathrm{UV} / \mathrm{US} / \mathrm{H}_{2} \mathrm{O}_{2}$ process}

As mentioned earlier, $\mathrm{H}_{2} \mathrm{O}_{2}$ alone could not reduce organics in wastewater. However, the addition of $\mathrm{H}_{2} \mathrm{O}_{2}$ to UV or US irradiation or their combination (US/UV) increases the efficiency of TOC reduction. Though, it should be considered that there is an optimum concentration of $\mathrm{H}_{2} \mathrm{O}_{2}$ that should be determined carefully. Overdose of the oxidant caused a reduction in organics removal effectiveness due to the recombination of hydroxyl radicals $\left({ }^{\circ} \mathrm{OH}\right)$ as well as the reaction of produced ${ }^{\circ} \mathrm{OH}$ with the excess $\mathrm{H}_{2} \mathrm{O}_{2}$ molecules to generate radicals, such as hydroperoxyl $\left(\mathrm{HO}_{2}{ }^{\circ}\right)$ which has less oxidizing power than ${ }^{\circ} \mathrm{OH}$ (Haji et al., 2011) (as shown in Reactions 2.7 and 2.10). Increasing the cost of the process is another problem associated with the overdose of $\mathrm{H}_{2} \mathrm{O}_{2}$. The low oxidant concentration, on the other hand, leads to the lack of ${ }^{\circ} \mathrm{OH}$ in the solution and decreases the degradation effectiveness.

In order to determine the optimum dosage of $\mathrm{H}_{2} \mathrm{O}_{2}$, different $\mathrm{H}_{2} \mathrm{O}_{2}$ concentrations in the range of 0 to $3000 \mathrm{mg} / \mathrm{L}$ were used. Three wastewater samples with initial TOC concentrations of 44.83 , 89.75, and $179.33 \mathrm{mg} / \mathrm{L}$ were applied for the experiments in batch recirculation mode. The results are shown in Figures 4.3 to 4.5. All the figures show the same trend and indicate an enhancement 
in TOC removal by increasing $\mathrm{H}_{2} \mathrm{O}_{2}$ concentrations up to an optimum dosage. Hydroxyl radicals produced by photolytic or sonolytic decomposition of $\mathrm{H}_{2} \mathrm{O}_{2}$, attack the organic matters in the solution. The maximum TOC removal for the sample with TOC of $44.83 \mathrm{mg} / \mathrm{L}$ was $63.95 \%$ after 90 min which achieved using $1750 \mathrm{mg} / \mathrm{L} \mathrm{H}_{2} \mathrm{O}_{2}$. Higher dosages of $\mathrm{H}_{2} \mathrm{O}_{2}$ reduced the ability of sonophotolysis process in elimination of organic content of the solution.

The optimal oxidant dosage for the two other SPWWs with higher TOC was found to be 2250 $\mathrm{mg} / \mathrm{L}$ which eventuated in $44.72 \%$ and $19.8 \%$ TOC removal, respectively.

Figure 4.6 compares the TOC removal for various TOC loading of pharmaceutical wastewater samples. The figure (4.6) confirms that at a higher wastewater concentration, the TOC removal capacity decreases due to the presence of more organic matter ready to compete for reaction with hydroxyl radicals ( $\left.{ }^{\circ} \mathrm{OH}\right)$.

In order to declare the results in a more practical form, it is recommended to determine the optimal molar ratio of $\left[\mathrm{H}_{2} \mathrm{O}_{2}\right] /[\mathrm{TOC}]$ (Tabrizi and Mehrvar, 2004; Barrera, 2011). The ratio of $\left[\mathrm{H}_{2} \mathrm{O}_{2}\right] /[\mathrm{TOC}]$ is an important parameter to optimize the wastewater treatment which could be used to adjust the $\mathrm{H}_{2} \mathrm{O}_{2}$ concentration based on the concentrations of organic matters present at any given time. Consequently, this factor assists to maximize the efficiency and diminish chemical and electrical expenses. According to the above results, Figure 4.8 represents optimal initial molar ratio of $\left[\mathrm{H}_{2} \mathrm{O}_{2}\right] /[\mathrm{TOC}]$ for the three wastewater samples. Molar ratio of 13.77 was found as the optimum for the SPWW with TOC of $44.83 \mathrm{mg} / \mathrm{L}$. The results are in accordance with data found in the open literature which reported the molar ratio between 0 and 100 (Tabrizi and Mehrvar, 2004; Pagano et al., 2008). 


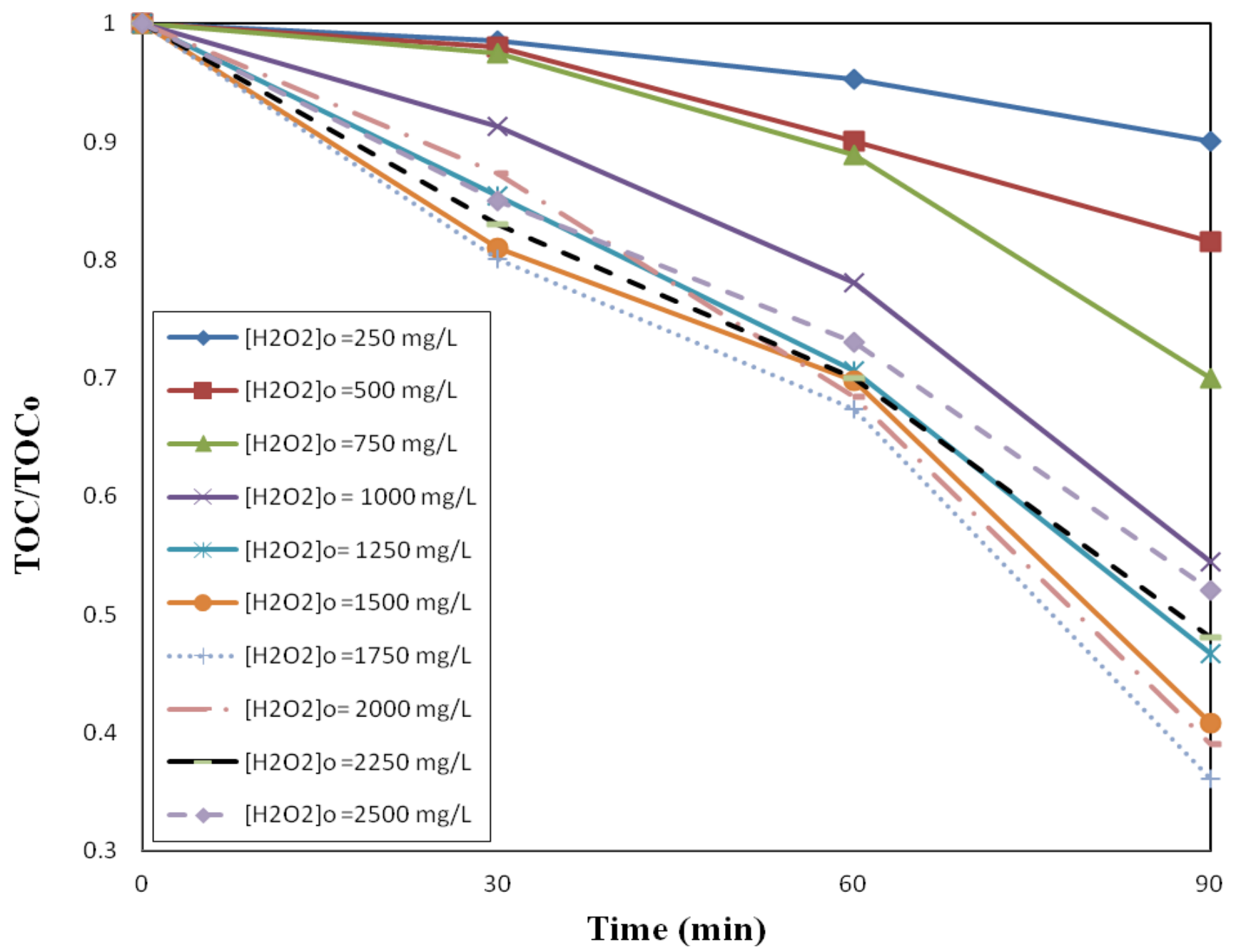

Figure 4.3. Effect of initial $\mathrm{H}_{2} \mathrm{O}_{2}$ concentration on TOC removal efficiency during batch mode $\mathrm{UV} / \mathrm{US} / \mathrm{H}_{2} \mathrm{O}_{2}$ process $\left([\mathrm{TOC}]_{0}=44.83 \mathrm{mg} / \mathrm{L}\right.$, US power $=140 \mathrm{~W}, \mathrm{pH}=3.9$ and airflow $=2$ L/min). 


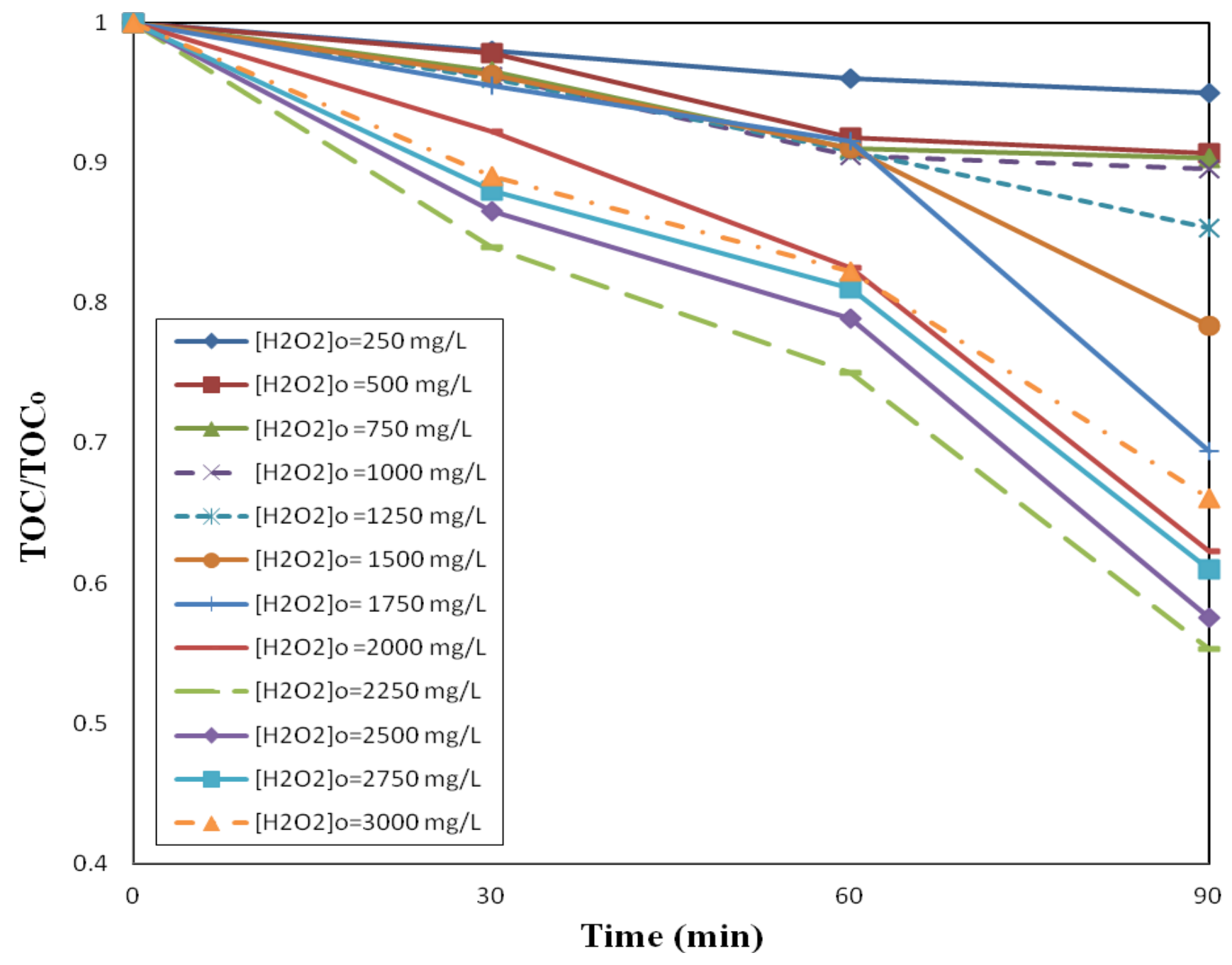

Figure 4.4. Effect of initial $\mathrm{H}_{2} \mathrm{O}_{2}$ concentration on TOC removal efficiency during batch mode $\mathrm{UV} / \mathrm{US} / \mathrm{H}_{2} \mathrm{O}_{2}$ process $\left([\mathrm{TOC}]_{0}=89.75 \mathrm{mg} / \mathrm{L}, \mathrm{US}\right.$ power $=140 \mathrm{~W}, \mathrm{pH}=3.9$ and airflow $=2$ $\mathrm{L} / \mathrm{min})$. 


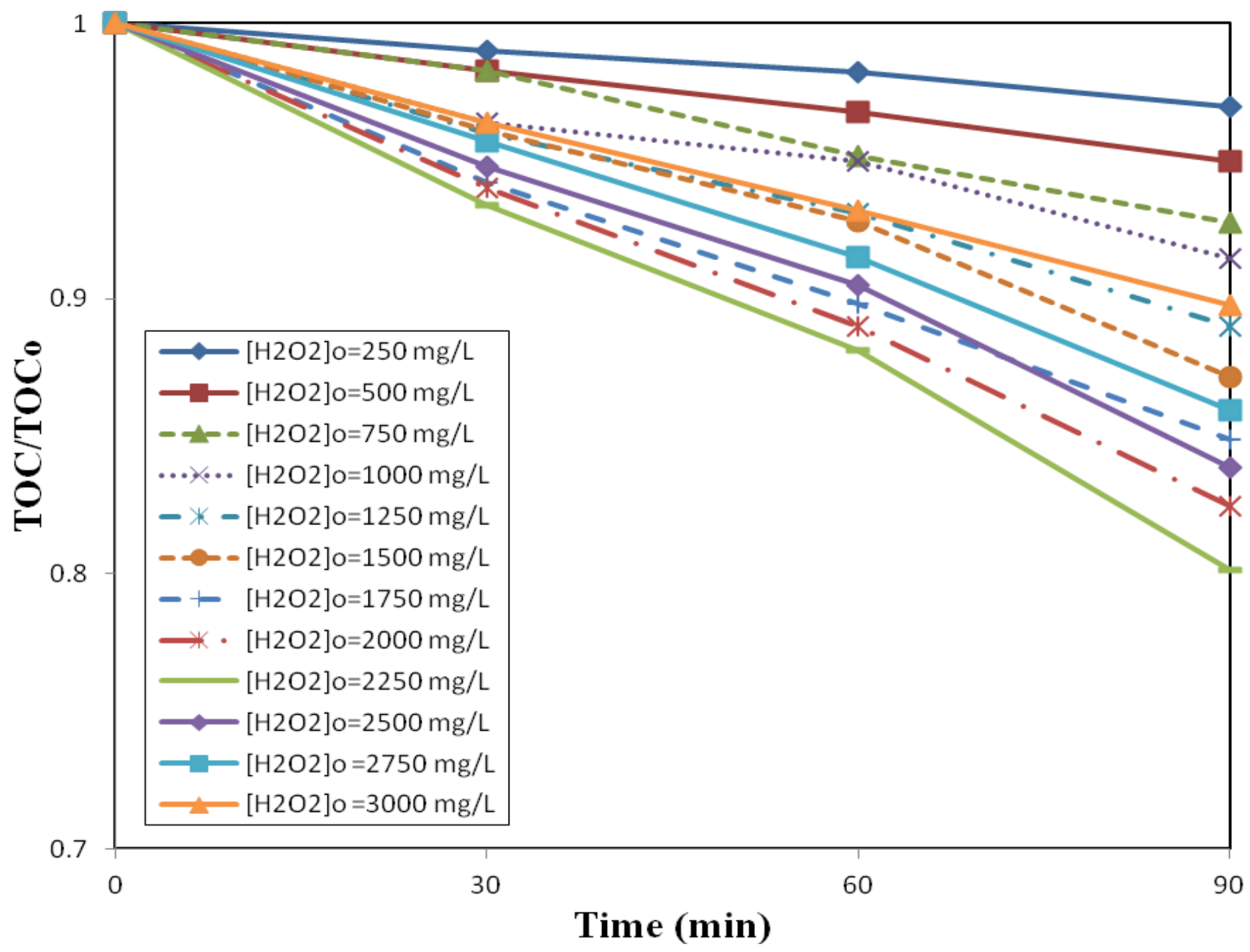

Figure 4.5. Effect of initial $\mathrm{H}_{2} \mathrm{O}_{2}$ concentration on TOC removal efficiency during batch mode $\mathrm{UV} / \mathrm{US} / \mathrm{H}_{2} \mathrm{O}_{2}$ process $\left([\mathrm{TOC}]_{0}=179.33 \mathrm{mg} / \mathrm{L}\right.$, US power $=140 \mathrm{~W}, \mathrm{pH}=3.9$ and airflow $=2 \mathrm{~L} / \mathrm{min}$ ). 


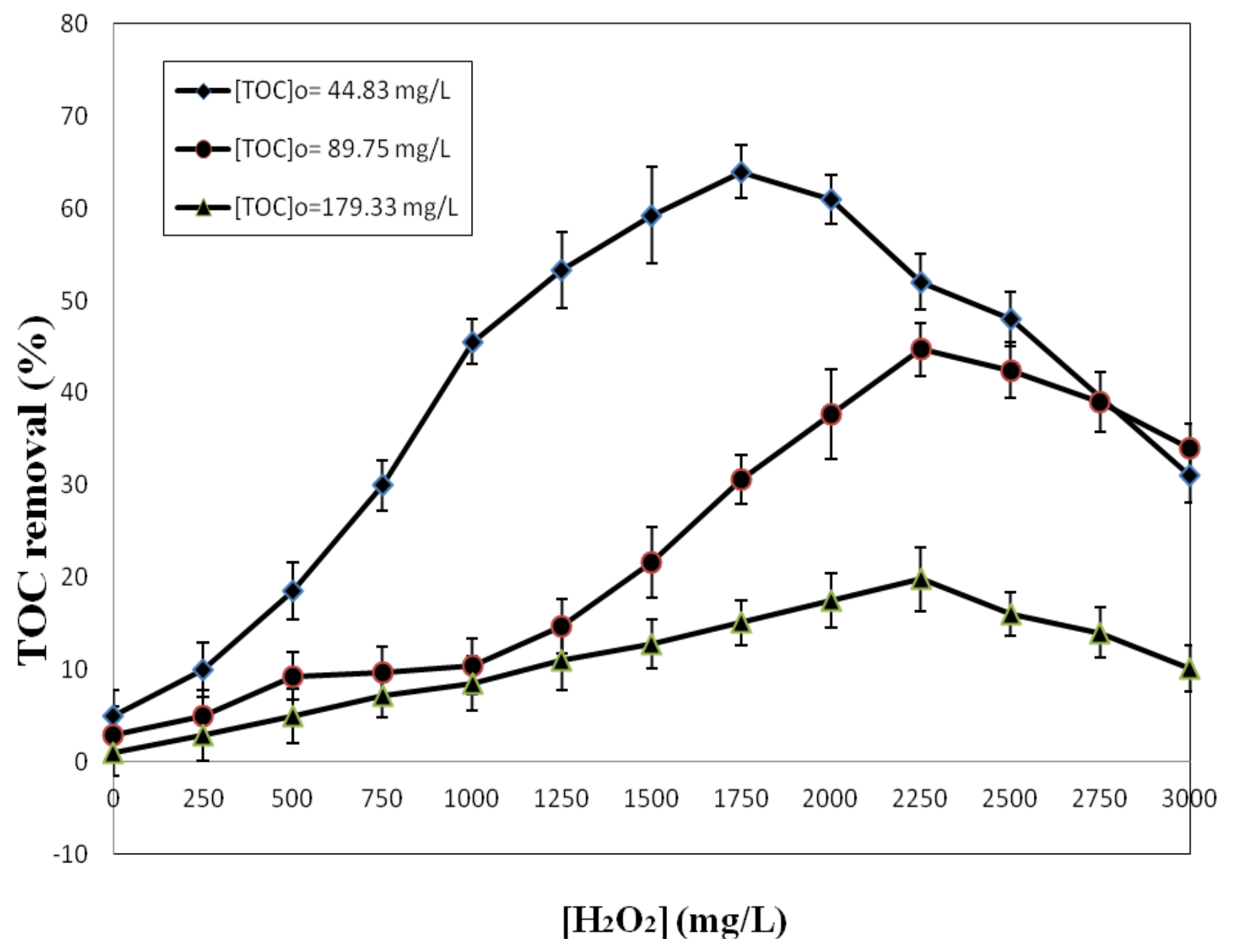

Figure 4.6. Optimal initial concentration of $\mathrm{H}_{2} \mathrm{O}_{2}$ for TOC removal in different SPWW concentrations, after 90 treatment by $\mathrm{UV} / \mathrm{US} / \mathrm{H}_{2} \mathrm{O}_{2}$ process in batch mode. 


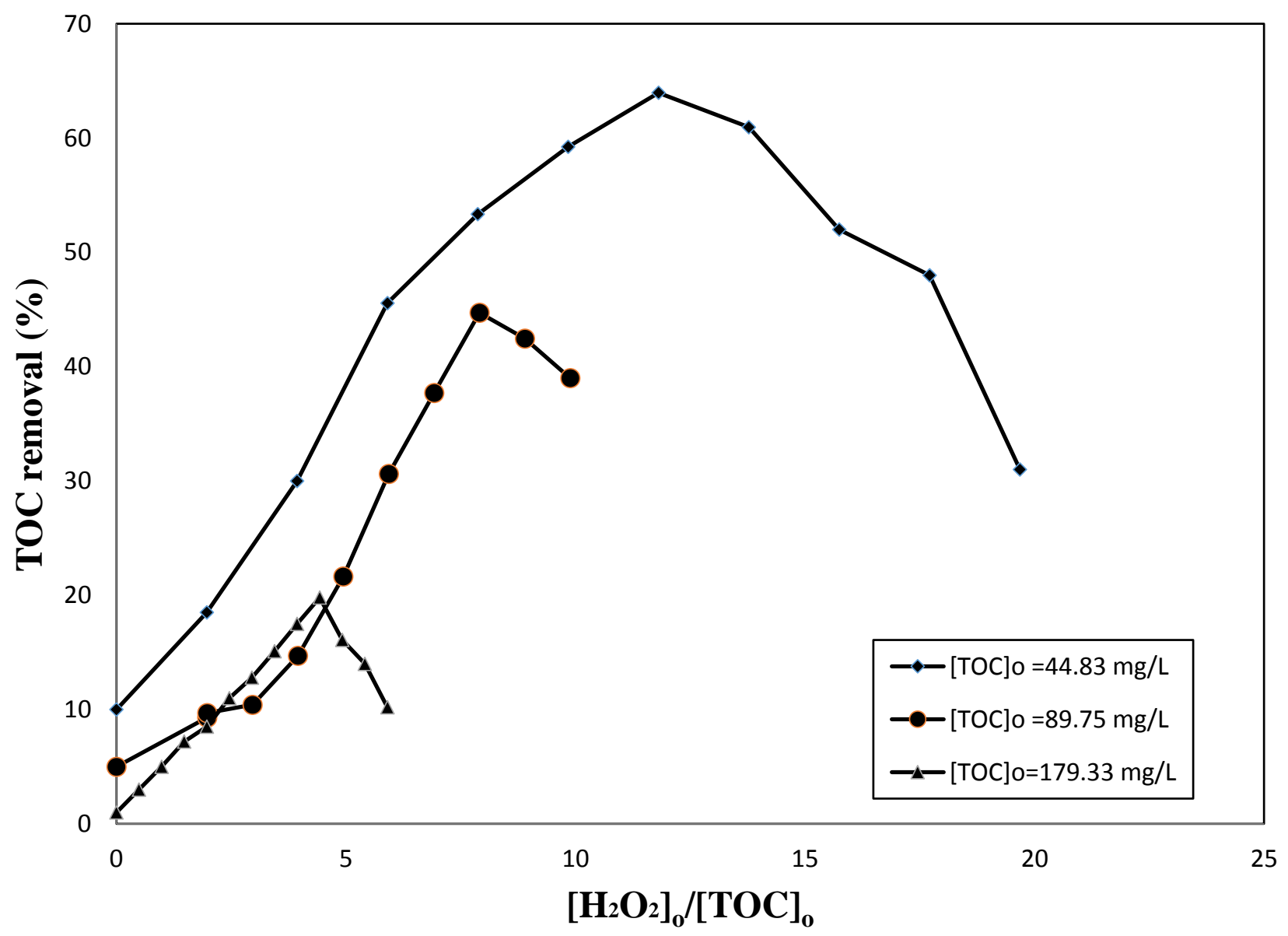

Figure 4.7. Relation of initial molar ratio of $\left[\mathrm{H}_{2} \mathrm{O}_{2}\right]_{0} /[\mathrm{TOC}]_{0}$ for different SPWW concentrations within the $\mathrm{UV} / \mathrm{US} / \mathrm{H}_{2} \mathrm{O}_{2}$ process in batch mode. 
The nitrogen loading of the SPWW was low. However, an experiment was conducted to evaluate treatment ability of sonophotolysis process for TN removal from the SPWW. The optimum $\mathrm{H}_{2} \mathrm{O}_{2}$ concentration found based on TOC removal data was used. Less than 5\% TN removal was observed after 90 min treatment under the sonophotolysis process.

\subsubsection{Effect of ultrasonic power on TOC removal}

Ultrasonic power was the second parameter which was studied to evaluate its effect on $\mathrm{UV} / \mathrm{US} / \mathrm{H}_{2} \mathrm{O}_{2}$ process in batch recirculation mode. Output powers of $20,60,100$ and 140 Watt were applied to the SPWW with the initial TOC of $44.83 \mathrm{mg} / \mathrm{L}$. Optimum $\mathrm{H}_{2} \mathrm{O}_{2}$ concentration of $1750 \mathrm{mg} / \mathrm{L}$ was used while other parameters kept constant $(\mathrm{pH}=3.9$, air flow rate $=2 \mathrm{~L} / \mathrm{min})$. As Figure 4.10 shows, increasing the applied US power from 20 to 140 Watt has improved TOC removal by about $19 \%$. Elevated US power causes higher rate of breakage of $\mathrm{H}_{2} \mathrm{O}_{2}$ molecules in aqueous solution (Na et al., 2012). Consequently, the concentration of hydroxyl radicals was increased and the produced radicals attack the organic matters. Furthermore, an increase in the ultrasonic power contributed to higher mixing intensity due to the turbulence and microstreaming which is generated during the cavitational microbubble collapse. To recap, higher ultrasonic

power results in higher number of cavitation, number of microbubble generated, formation of hydroxyl radicals, mass transfer, and more degradation of pollutants (Mason et al., 1992; 


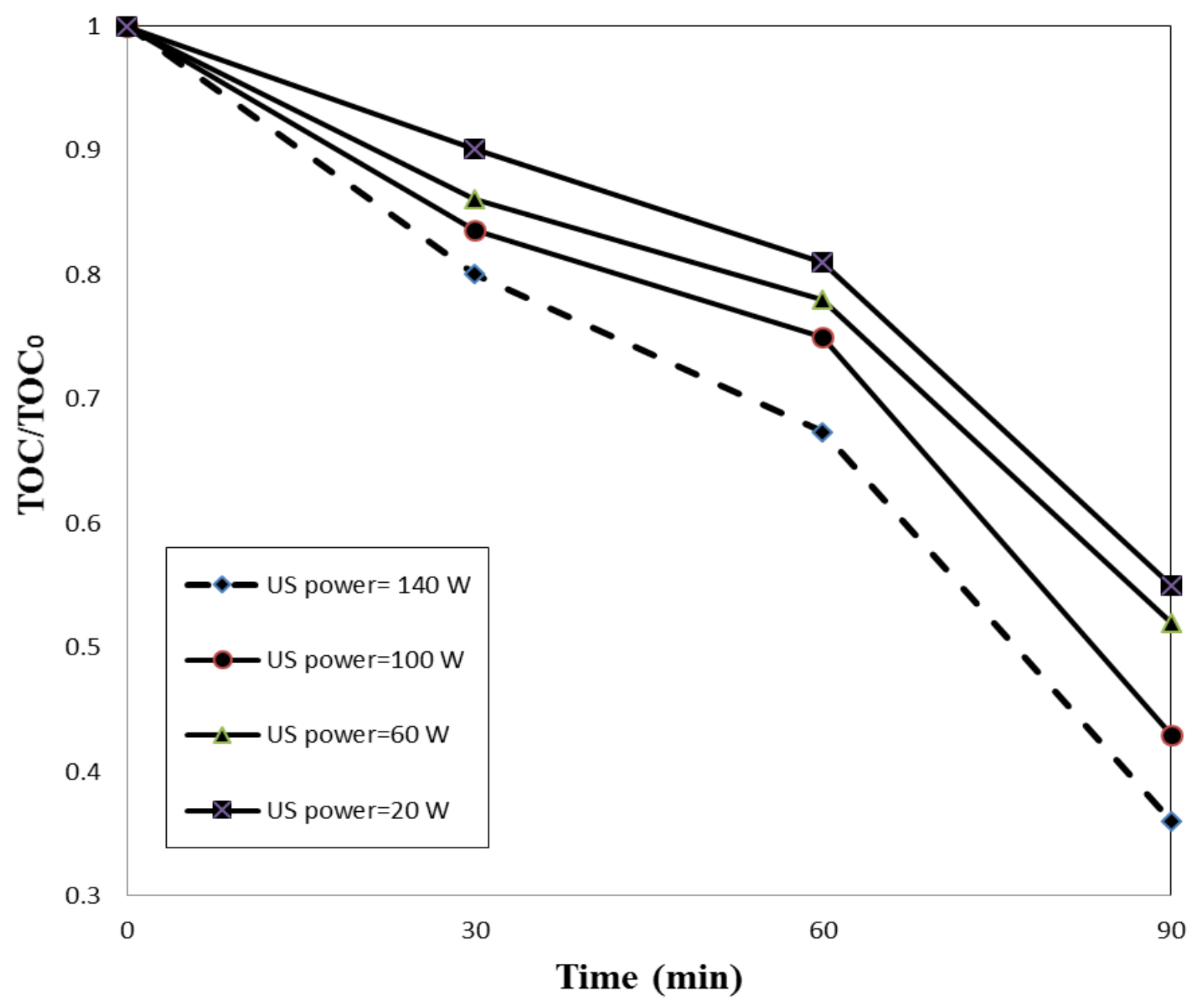

Figure 4.8. Effect of ultrasonic power on TOC removal efficiency during batch $\mathrm{US} / \mathrm{UV} / \mathrm{H}_{2} \mathrm{O}_{2}$ process $\left([\mathrm{TOC}]_{0}=44.83 \mathrm{mg} / \mathrm{L},\left[\mathrm{H}_{2} \mathrm{O}_{2}\right]_{\mathrm{o}}=1750 \mathrm{mg} / \mathrm{L}, \mathrm{pH}=3.9\right.$, and air flow rate: $\left.2 \mathrm{~L} / \mathrm{min}\right)$. 
Mohajerani, 2012). Same results could be found in the open literature. Torres et al. (2008) reported that increasing US power from 20 to $80 \mathrm{~W}$ enhances the degradation of bisphenol A in water. The ibuprofen degradation was also improved by increasing US power (Mendez-Arriaga et al., 2008). In a recent study, (Na et al., 2012) degradation rate constant of diethyl phthalate increased by more than 3 times while enhancing US power from 45 to $80 \mathrm{~W} / \mathrm{L}$. The results of this study as well as data from literature confirms the importance of US output power on competence of both sonolysis and sonophotolysis processes

\subsubsection{Effect of initial pH of the SPWW on TOC removal}

The initial $\mathrm{pH}$ of solution is a critical parameter which affects the efficiency of most AOPs. The data regarding the effect of $\mathrm{pH}$ on the $\mathrm{UV} / \mathrm{US} / \mathrm{H}_{2} \mathrm{O}_{2}$ process is limited. Duran et al. (2013) reported an increase in TOC removal while increasing $\mathrm{pH}$ from 2 to 8 for the treatment of food processing industry wastewater treatment using the $\mathrm{UV} / \mathrm{US} / \mathrm{H}_{2} \mathrm{O}_{2}$ process. Another recent report by Xu et al. (2013) studied the degradation of dimethyl phthalate by US/UV process and stated a systematic reduction in dimethyl phthalate degradation by increasing the $\mathrm{pH}$ in the range of 2 to 10. In the present study, the TOC removal was observed under sonophotolysis process by changing $\mathrm{pH}$ in the range of 2 to 8 . The optimal Initial $\mathrm{H}_{2} \mathrm{O}_{2}$ concentration of $1750 \mathrm{mg} / \mathrm{L}$ and optimal US power of $140 \mathrm{~W}$ were applied while air flow rate was kept at $2 \mathrm{~L} / \mathrm{min}$. Data are shown in Figure 4.11 and it was found that by increasing $\mathrm{pH}$, TOC reduction decreased with an exception in alkaline $\mathrm{pH}$ of 8 . An explanation to this trend may be due to the reduction of oxidation potential of hydroxyl radicals while $\mathrm{pH}$ is elevated. In addition, the fast consumption of hydroxyl radicals in alkaline medium must be considered (Reaction 4.1).

$\cdot \mathrm{OH}+\mathrm{OH}^{-} \rightleftarrows \mathrm{H}_{2} \mathrm{O}+\mathrm{O}^{-}$ 
In Reaction 4.1, $\mathrm{k}$ forward and $\mathrm{k}$ backward are $1.2 \times 10^{10} \mathrm{M}^{-1} \mathrm{~S}^{-1}$ and $9.3 \times 10^{7} \mathrm{~S}^{-1}$, respectively (Hamdaoui and Naffrechoux, 2008).

The effect of $\mathrm{pH}$ on the rates of degradation in sonophotolysis process is also reliant on the state of the contaminant molecule, whether the pollutant is present as ionic species or as a molecule. Several studies reported that the degradation rate is lowest at the $\mathrm{pH}$ range which the pollutant is in its ionized form (Ashokkumar et al., 2000; Mohajerani, 2012; Hamdaoui and Naffrechoux, 2008). This behavior is due to the fact that components are nonvolatile and more stabilized at their ionized form. So they react with ${ }^{\circ} \mathrm{OH}$ only at microbubbles surfaces. On the other hand, in molecular form, they can enter the vapor phase; consequently, they decomposed both, by thermolytic cleavage and reaction with ${ }^{\circ} \mathrm{OH}$ in aqueous solution.

\subsubsection{Effect of air flow rate on TOC removal}

Air flow rate was the last parameter which was studied to observe its effect on the TOC removal during the UV/US/ $\mathrm{H}_{2} \mathrm{O}_{2}$ process. Air flow rates in the range of 1 to $5 \mathrm{~L} / \mathrm{min}$ were applied while other parameters adjusted to their optimal values found in previous steps $\left(\left[\mathrm{H}_{2} \mathrm{O}_{2}\right]=1750 \mathrm{mg} / \mathrm{L}\right.$, US Power $=140 \mathrm{~W}$ and $\mathrm{pH}=2$ ). The results are demonstrated in Figure 4.12. Increasing the flow rate from 1 to $3 \mathrm{~L} / \mathrm{min}$ improved the TOC removal from 59 to $73 \%$. Further increase in air flow rate did not affect the TOC removal significantly and around 57\% TOC removal achieved for flow rates of 4 and $5 \mathrm{~L} / \mathrm{min}$.

Several researchers stated positive effect of gas sparging in the enhancement of sonochemical process (Mason et al., 2003; Mendez-Arriaga et al., 2008). Naddeoa et al. (2009) reported greater degradation of a pharmaceutical wastewater under US irradiation under continuous air sparging in comparison to the degradation in the absence of air. 


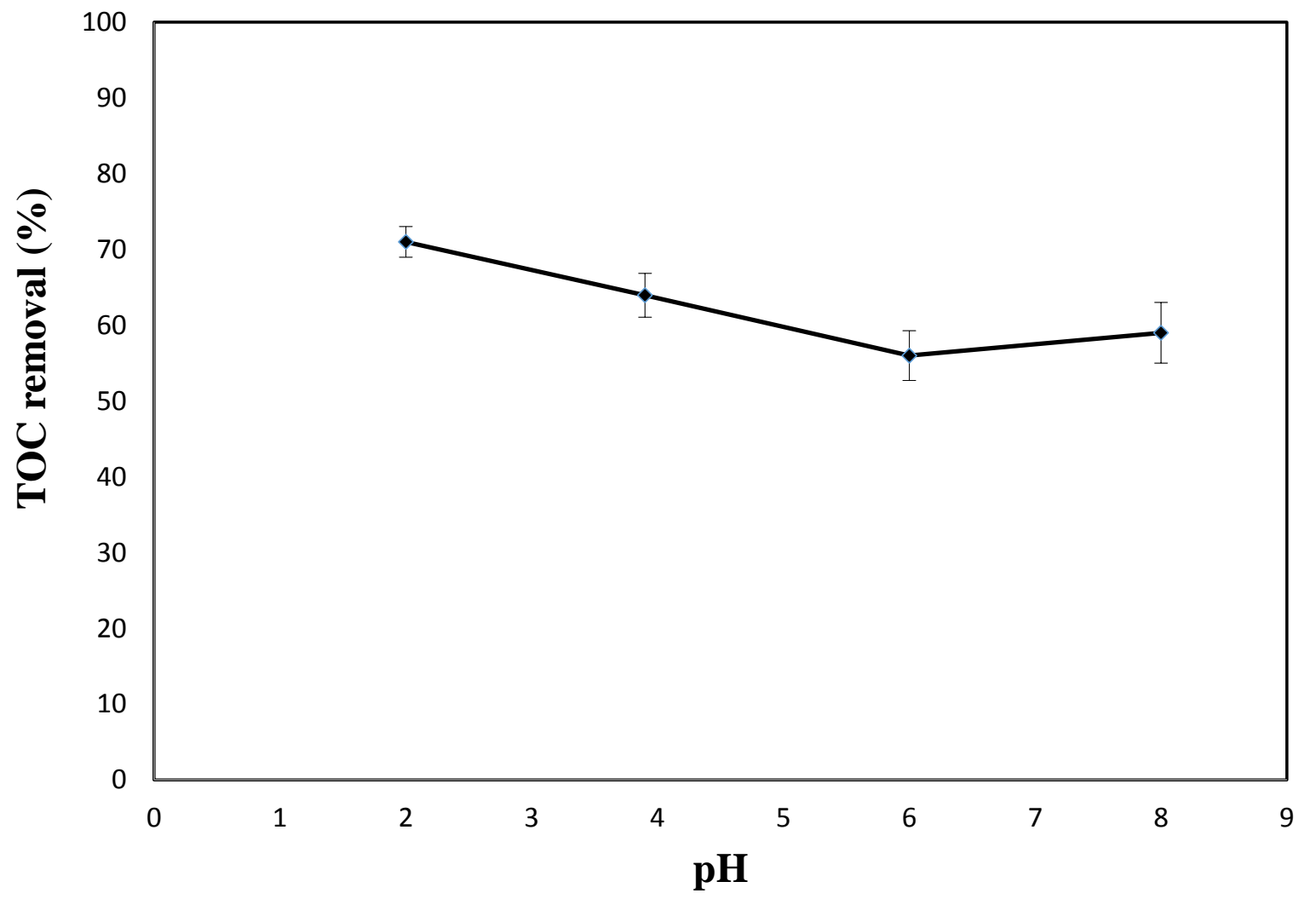

Figure 4.9. Effect of initial pH of the SPWW on TOC removal efficiency after 90 min batch mode US/UV/ $/ \mathrm{H}_{2} \mathrm{O}_{2}$ process $\left([\mathrm{TOC}]_{o}=44.83 \mathrm{mg} / \mathrm{L},\left[\mathrm{H}_{2} \mathrm{O}_{2}\right]_{0}=1750 \mathrm{mg} / \mathrm{L}\right.$, US Power $=140 \mathrm{~W}$ and air flow rate: $2 \mathrm{~L} / \mathrm{min}$ ). 


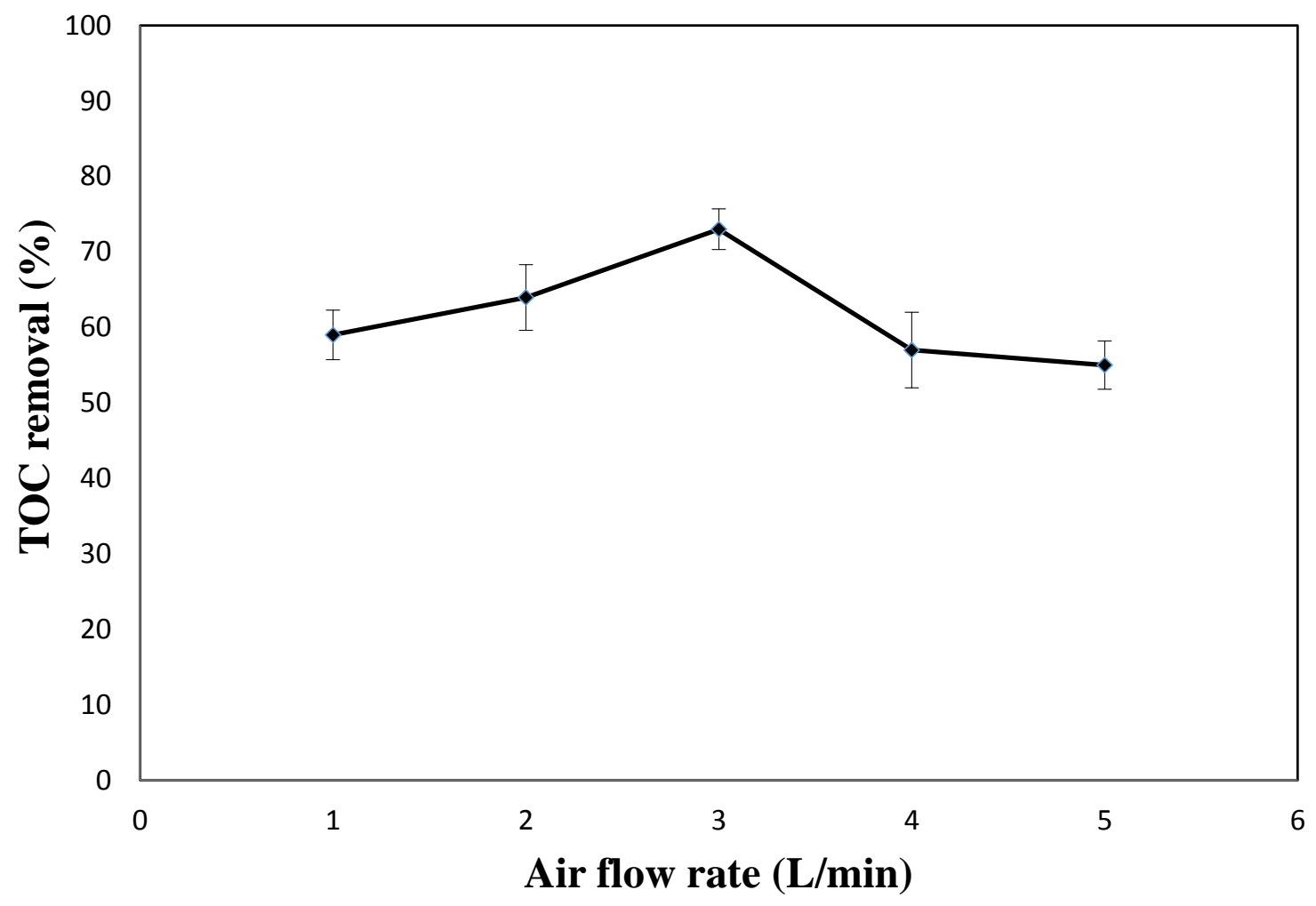

Figure 4.10. Effect of air flow rate on TOC removal efficiency after 90 min batch mode $\mathrm{US} / \mathrm{UV} / \mathrm{H}_{2} \mathrm{O}_{2}$ process $([\mathrm{TOC}] \mathrm{o}=\mathbf{4 4 . 8 3} \mathrm{mg} / \mathrm{L},[\mathrm{H} 2 \mathrm{O} 2] \mathrm{o}=1750 \mathrm{mg} / \mathrm{L}$, US Power $=140 \mathrm{~W}$ and pH=2). 
They mentioned that this improved results is due to the fact that gases operate as nucleation site for cavitation. Adverse effect of high air flow rates (4 and $5 \mathrm{~L} / \mathrm{min}$ ) could be described by considering the lower residence time of organics in the sonophotreactor which caused by higher liquid circulation during the treatment with elevated air flow rates.

\subsection{TOC, COD, and TN Removal in SPWW Using Aerobic}

\section{Activated Sludge Process}

Biological treatment using the aerobic AS process in continuous mode in a laboratory scale reactor was studied to treat the SPWW. Four hydraulic retention times (HRT) of 12, 24, 36 and 48 $\mathrm{h}$ were used with the TOC loading rates of $0.93-15 \mathrm{mg} /(\mathrm{L} . \mathrm{h})$ and TN loading rates of $0.064-0.85$ $\mathrm{mg} /(\mathrm{L} . \mathrm{h})$. Results are presented in Figures 4.13, 4.14, and 4.15. The optimum retention time for aerobic AS process was $24 \mathrm{~h}$ since there was no significant change in TOC removal for retention times over $24 \mathrm{~h}$. The TOC removal after $24 \mathrm{~h}$ retention time was 65,69 and $73 \%$ for the three SPWW samples. For HRT of 48 h, 67, 71 and $76 \%$ TOC reduction were observed which shows only a slight improvement. Also, in the case of TN removal, the results were in the range of 32 to $60 \%$ for HRT of $24 \mathrm{~h}$ and in the range of 52 to $65 \%$ for HRT of $48 \mathrm{~h}$. Furthermore, it was also observed that at higher influent TOC and TN concentrations, the TOC and TN removal rates were higher. Figure 4.15 depicts the COD removal percentage. The COD removal trend is different from those of TOC and TN. Since by decreasing the inlet COD, the removal increases. Maximum $82 \%$ COD removal was observed after $24 \mathrm{~h}$ retention time for the SPWW with lowest inlet COD. After 24 $\mathrm{h}$ there is almost no change. So there is a consistency with previous results of TOC and TN removal. The treatment ability of aerobic AS process was not satisfactory more than 95\% TOC removal is the goal to meet the standard regulations. These unsatisfactory results are attributed to the 


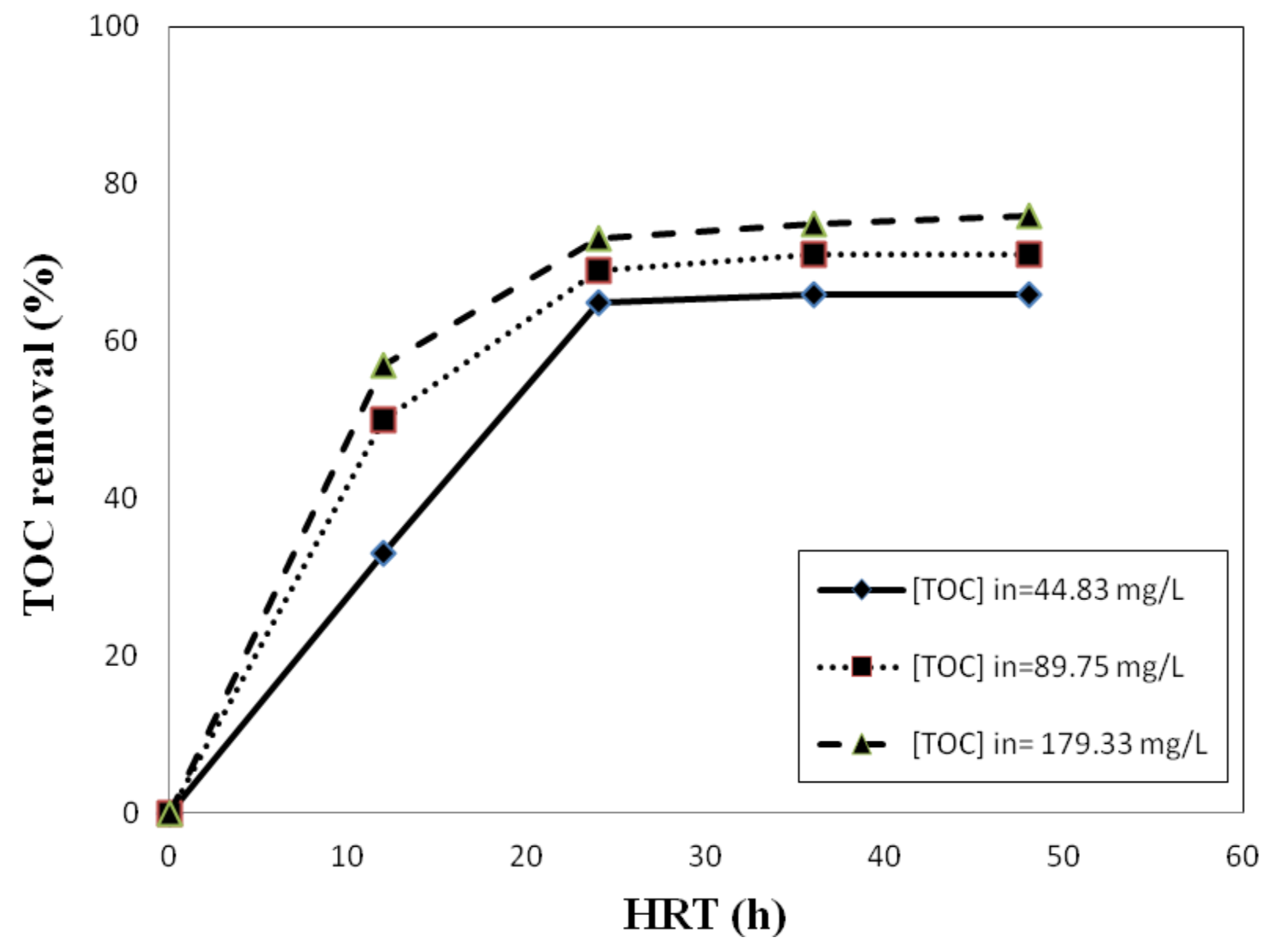

Figure 4.11. TOC removal for different SPWW concentrations at various HRT using aerobic activated sludge treatment in continuous mode without recirculation. 


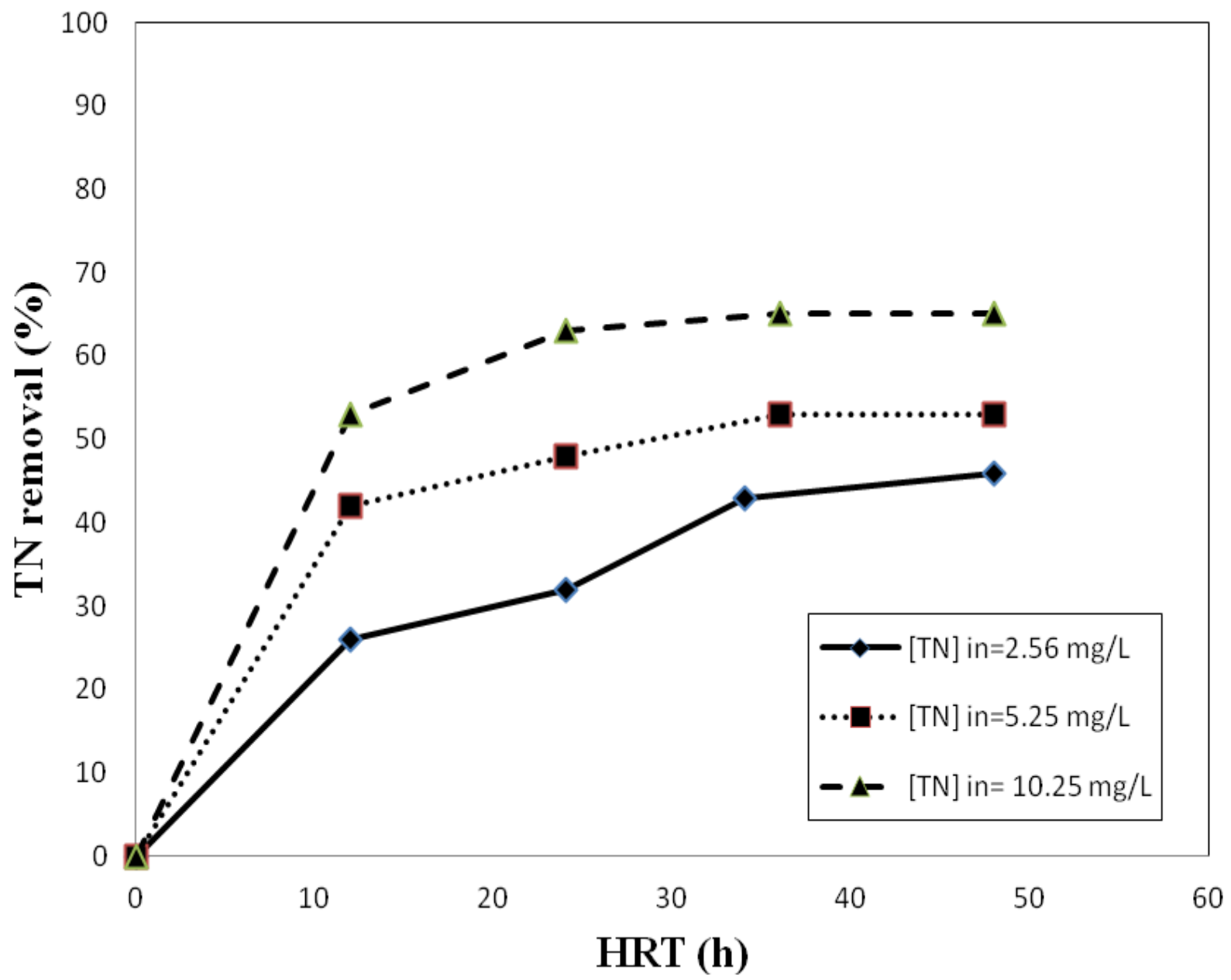

Figure 4.12. TN removal for different SPWW concentrations at various HRT using aerobic activated sludge treatment in continuous mode without recirculation. 


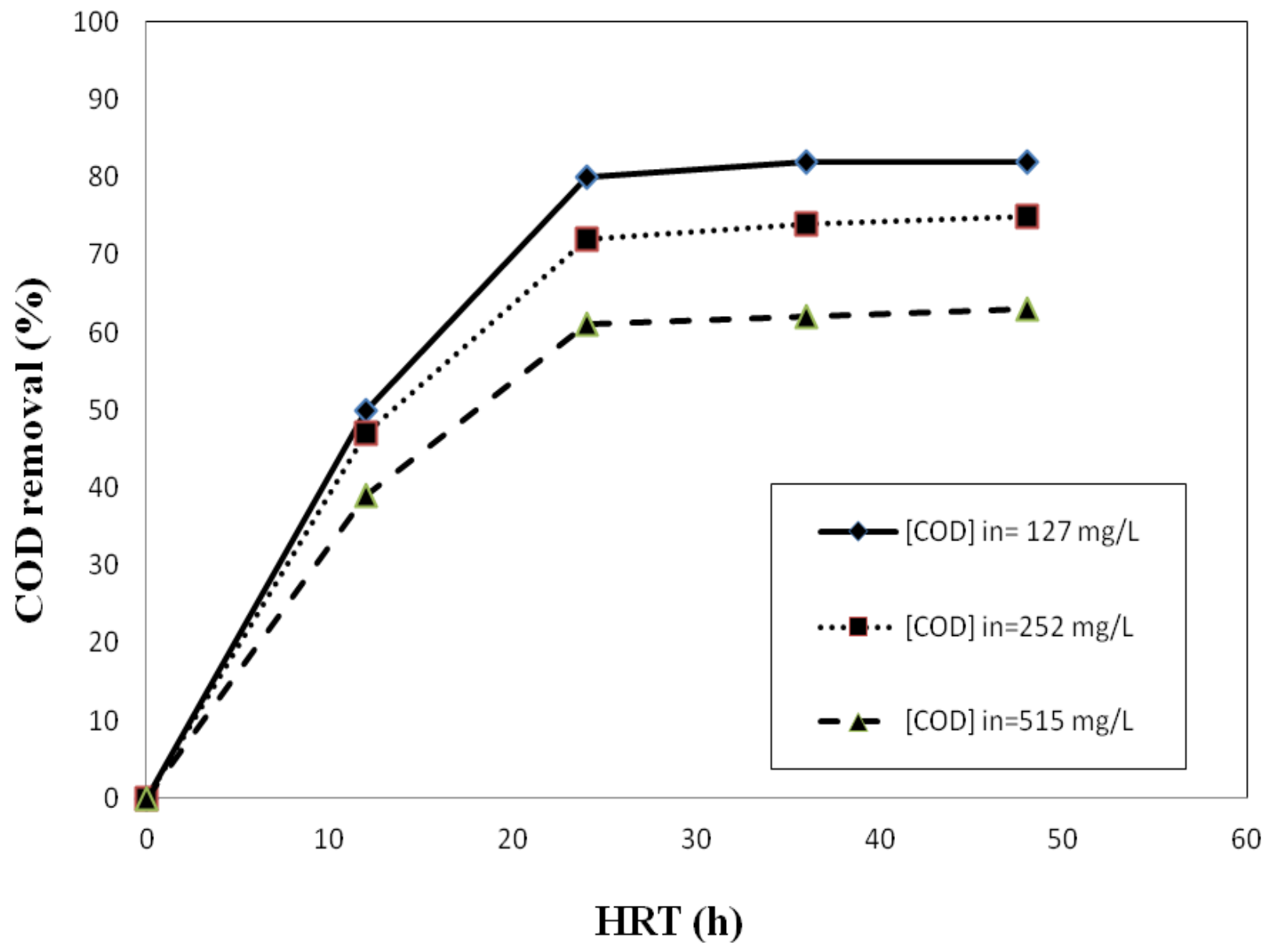

Figure 4.13. COD removal for different SPWW concentrations at various HRT using aerobic activated sludge treatment in continuous mode without recirculation. 
existence of nonbidegradable components which are usually remains unaltered in the effluent of biological treatment systems. In order to achieve high removal efficiency, the application of advanced oxidation technologies as pre-treatment seems crucial. However, in order to make the treatment process practically economical, the combination of AOPs with biological process can be a good alternative. This combination will be discussed in the next section.

\subsection{TOC, COD, and TN Removal in SPWW Using Combined}

\section{$\mathrm{UV} / \mathrm{US} / \mathrm{H}_{2} \mathrm{O}_{2}$ and Aerobic AS Processes}

It was observed in Section 4.4 that the SPWW samples were approximately nonbiodegradable and the aerobic AS process was only able for the partial treatment of the wastewater. On the other hand, $\mathrm{UV} / \mathrm{US} / \mathrm{H}_{2} \mathrm{O}_{2}$ using the optimal operating conditions showed a significant efficiency in the TOC removal. However, achieving complete removal of pollutants require longer reaction time and higher consumption of chemicals which make the treatment expensive. Therefore, the combination of the two processes is studied in this section in order to accomplish greater removal of TOC, COD, and TN while trying to make the treatment economical by reducing the usage of chemicals and finding an optimum retention time for transferring the wastewater from sonophotoreactor to the bioreactor.

In this section, the processes were performed in continues mode to investigate the biodegradability of treated SPWW in different hydraulic retention times under UV/US/ $\mathrm{H}_{2} \mathrm{O}_{2}$

process. Continuous mode studies were performed only on the SPWW with the inlet TOC of $44.83 \mathrm{mg} / \mathrm{L}$. Biodegradability studies were carried out based on evolution of $\mathrm{BOD}_{5} / \mathrm{COD}$ ratio and the average oxidation state of the wastewater samples during the treatment. Additionally, 
since the effluent of the sonophotoreactor would be introduced to the bioreactor, the concentration of $\mathrm{H}_{2} \mathrm{O}_{2}$ should be minimized. So, the concentration profile of hydrogen peroxide was determined during the UV/US/ $\mathrm{H}_{2} \mathrm{O}_{2}$ process. According to the results from biodegradability studies and $\mathrm{H}_{2} \mathrm{O}_{2}$ concentration profile, the optimum retention time to transfer of the SPWW from the sonophotoreactor to bioreactor was determined.

In the second step, using the results found from continuous mode studies, the SPWW was pretreated in the sonophotoreactor and the effluent was introduced to the aerobic AS reactor. A complete discussion of the results is provided in the next sections.

\subsection{1 $\mathrm{UV} / \mathrm{US} / \mathrm{H}_{2} \mathrm{O}_{2}$ as pre-treatment in continuous mode}

According to the results of batch mode studies, continuous mode experiments were conducted using US power of $140 \mathrm{~W}, \mathrm{pH} 2$, air flow rated of $3 \mathrm{~L} / \mathrm{min}$, and various $\mathrm{H}_{2} \mathrm{O}_{2}$ concentrations at different hydraulic retention times from 30 to 180 min. TOC profile is presented in Figures 4.16. The results are in accordance with batch mode experiments. Increasing the inlet $\mathrm{H}_{2} \mathrm{O}_{2}$ concentration increased the TOC removal. Under the optimum condition approximately $90 \%$ removal was observed which confirmed the high treatment ability of the UV/US/ $\mathrm{H}_{2} \mathrm{O}_{2}$ process.

In order to achieve high treatment efficiency in bioreactors while combining them with AOPs, it should be considered that the effluent of the AOP reactor should be biodegradable. Also, it has been proven that high concentrations of hydrogen peroxide can be harmful to bacterial activity (Scott and Ollis, 1995). Studying the two mentioned factors (biodegradability and residual hydrogen peroxide concentration) help to find the optimum point for transferring the wastewater from sonophotoreactor to the aerobic AS reactor. 


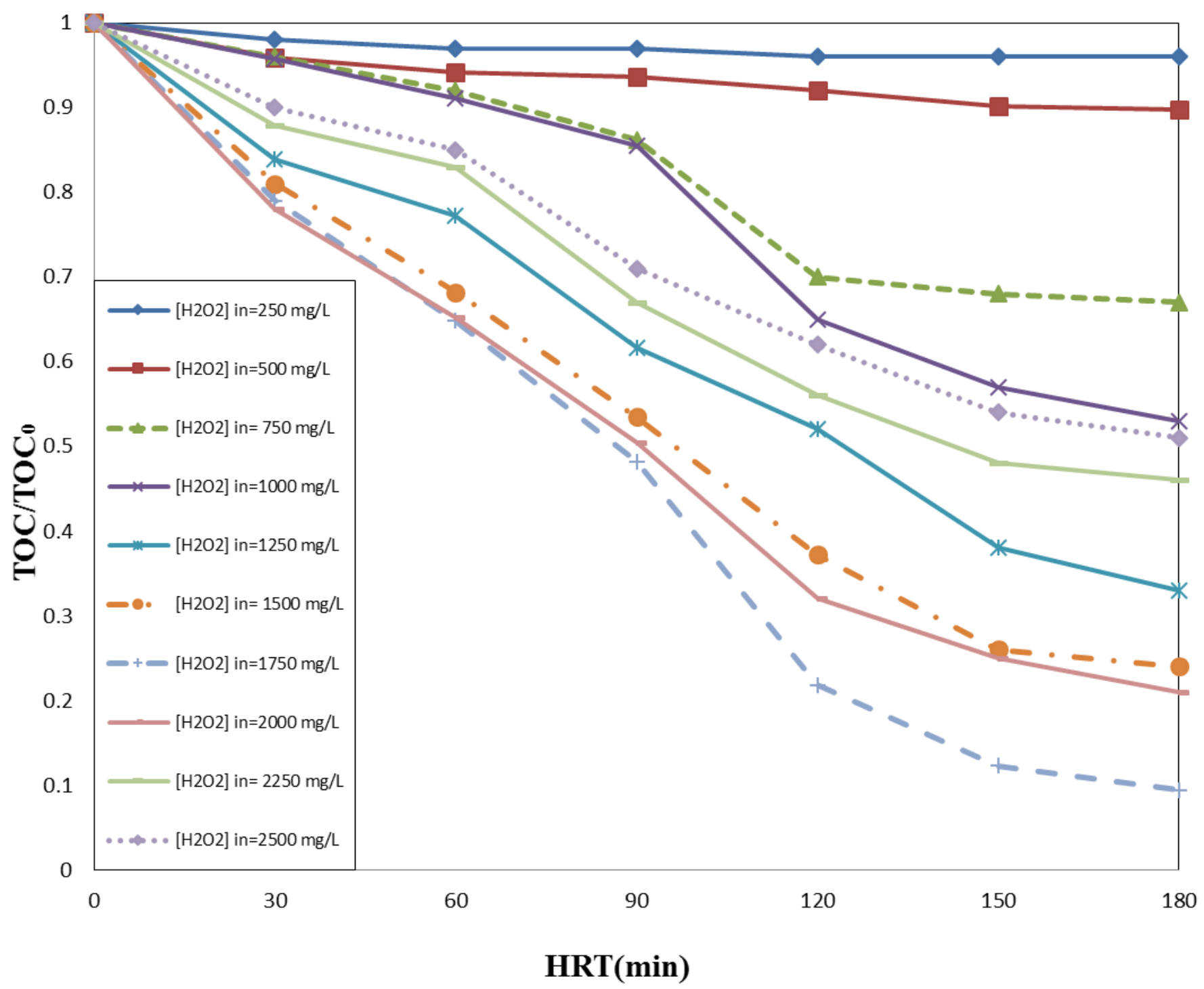

Figure 4.14. TOC removal using different $\mathrm{H}_{2} \mathrm{O}_{2}$ concentrations with inlet TOC concentration of $44.83 \mathrm{mg} / \mathrm{L}$ during continuous mode $\mathrm{UV} / \mathrm{US} / \mathrm{H}_{2} \mathrm{O}_{2}$. 
From the results presented in Figure 4.16, it is shown that TOC removal using $250 \mathrm{mg} / \mathrm{L} \mathrm{H}_{2} \mathrm{O}_{2}$ is marginal. Only 4\% TOC removal was observed. Additionally, it is obvious that using more than optimum dosage of $\mathrm{H}_{2} \mathrm{O}_{2}$ will have negative effect on the treatment both economically and operationally. Therefore, for further studies in this section, we focused on inlet $\mathrm{H}_{2} \mathrm{O}_{2}$ concentrations of 500, 750, 1000, 1250, 1500 and $1750 \mathrm{mg} / \mathrm{L}$.

\subsubsection{Biodegradability Studies}

There are various parameters which can be used to determine the biodegradability of wastewater samples. Common methods include the ratio of $\mathrm{BOD}_{5} / \mathrm{COD}$ or $\mathrm{BOD}_{5} / \mathrm{TOC}$, which are proposed by several authors (Van Aken et al., 2013; Contreras et al., 2003; Takahashi et al., 1994). Typically, the $\mathrm{BOD}_{5} / \mathrm{COD}$ ratio of 0.4 or more is considered as biodegradable wastewater (Contreras et al., 2003). Another parameter which is a measure of the oxidation state of the wastewater is the average oxidation state (AOS) which was used by several authors as well (Sitori et al., 2009; Silva et al., 2013). In order to evaluate the biodegradability of the untreated SPWW samples, BOD5/COD was measured and as shown in Figure 4.17. This figure shows, the $\mathrm{BOD}_{5} / \mathrm{COD}$ ratio for wastewater samples is far from 0.4. AOS for the three SPWW with TOC concentrations of $44.83,89.75$, and $179.33 \mathrm{mg} / \mathrm{L}$ were $-0.24,-0.19$ and -0.30 respectively. These data states that the SPWW samples are not biodegradable and pre-treatment before aerobic AS process is required.

The evolution of BOD5/COD ratio and AOS for the wastewater with initial TOC of $44.83 \mathrm{mg} / \mathrm{L}$ was investigated during the $\mathrm{UV} / \mathrm{US} / \mathrm{H}_{2} \mathrm{O}_{2}$ process. Results are illustrated in Figures 4.19 and 4.20. Increasing the HRT from 0 to 120 min improve the AOS significantly. However, AOS remains almost constant in HRT of 150 and 180 for all experiments except for the experiment with initial 


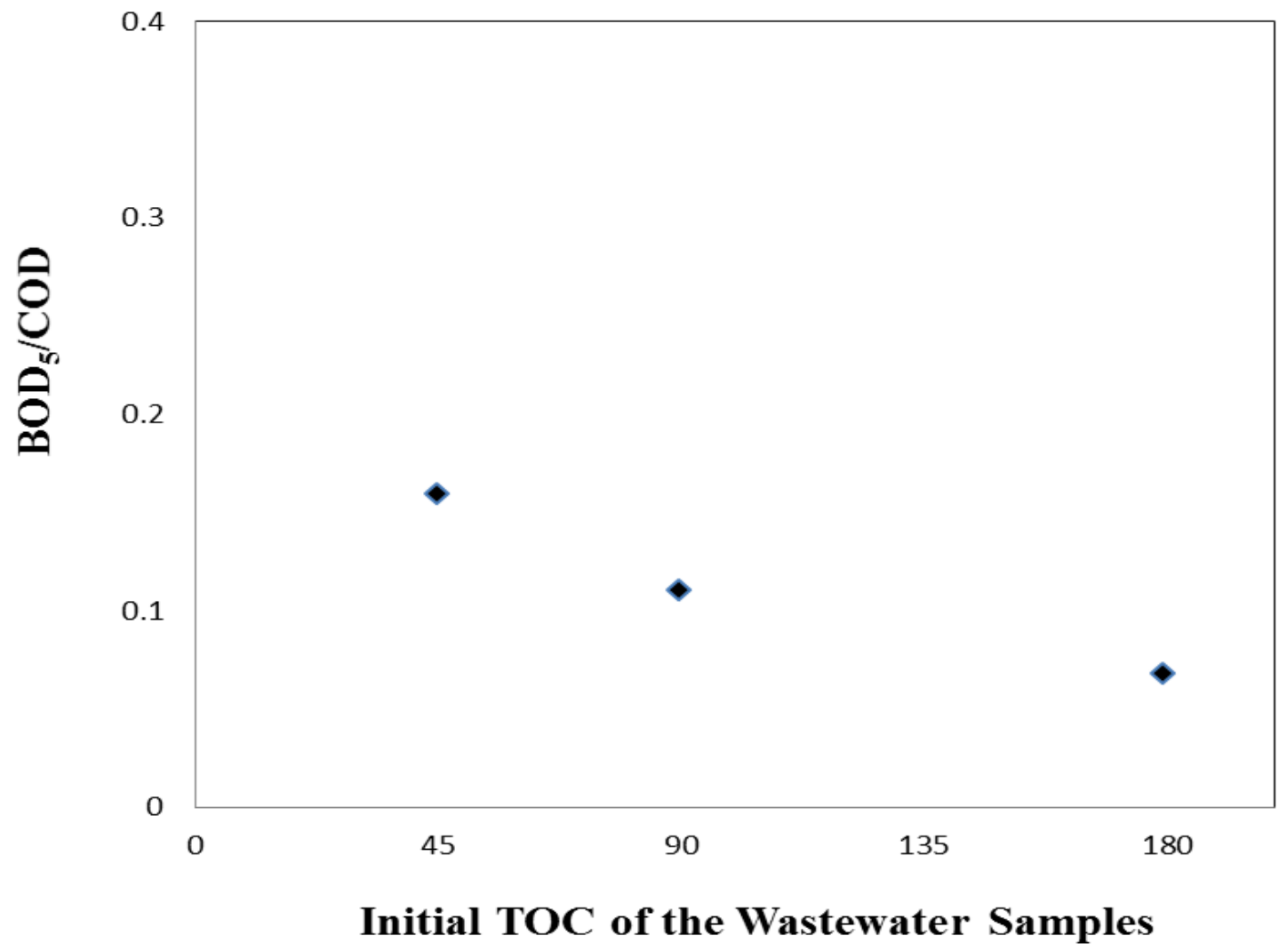

Figure 4.15. BOD $_{5} / \mathrm{COD}$ ratio of the pharmaceutical wastewater. 


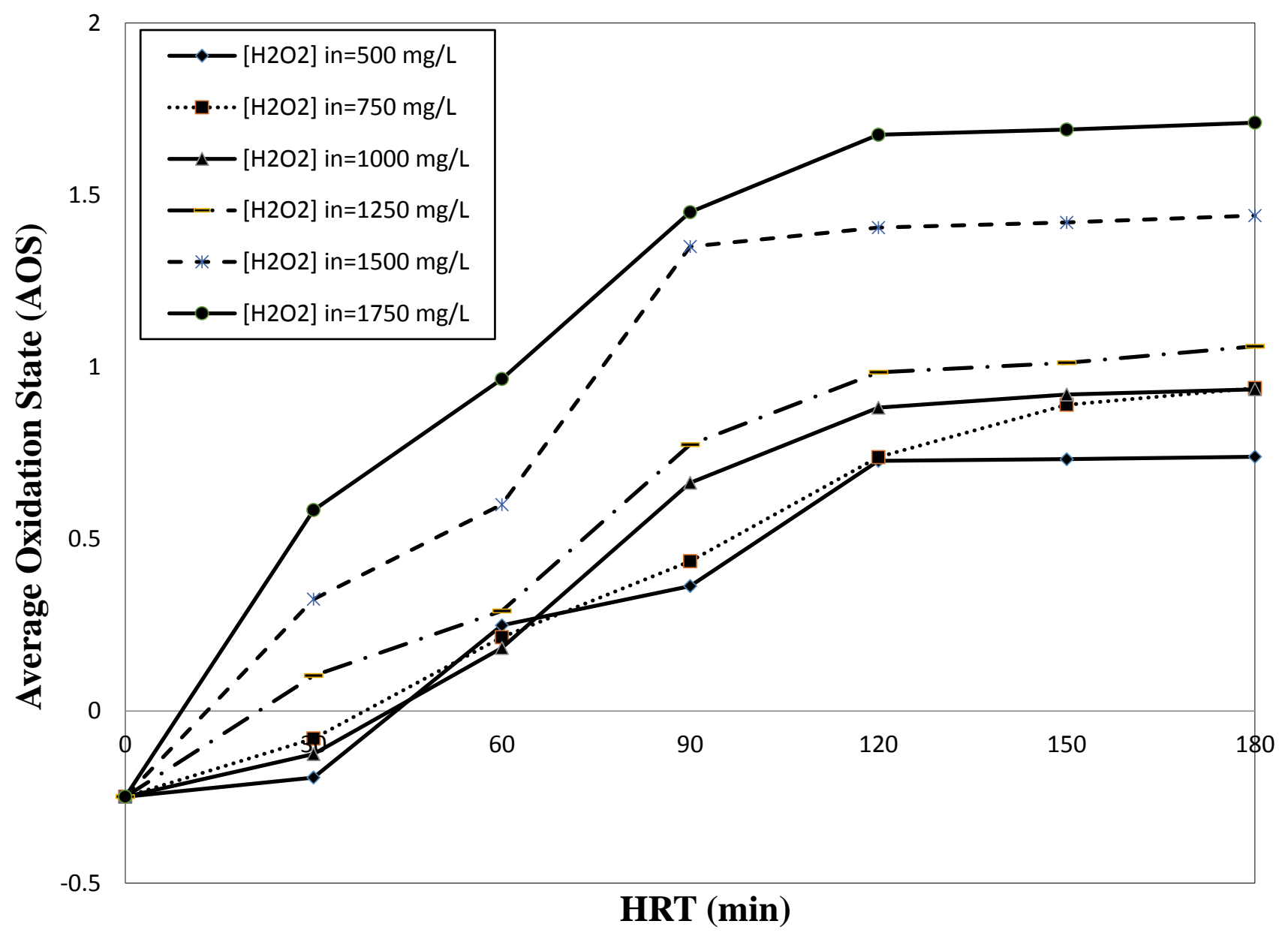

Figure 4.16. Evolution of average oxidation state during $\mathrm{UV} / \mathrm{US} / \mathrm{H}_{2} \mathrm{O}_{2}$ process at various HRT, $[\text { TOC }]_{\text {in }}=44.83 \mathrm{mg} / \mathrm{L}$. 


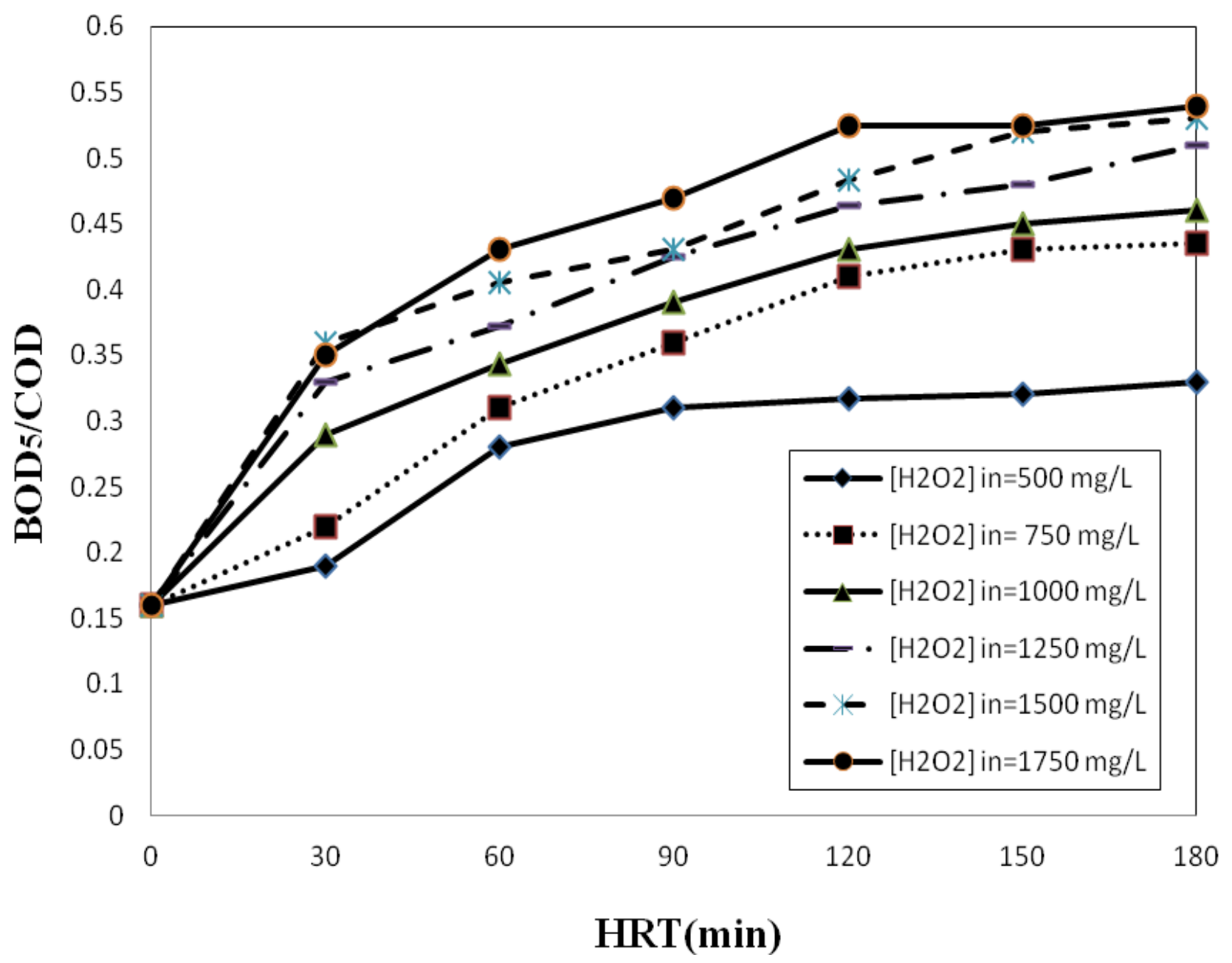

Figure 4.17. Evolution of $\mathrm{BOD}_{5} / \mathrm{COD}$ ratio during $\mathrm{UV} / \mathrm{US} / \mathrm{H}_{2} \mathrm{O}_{2}$ process at various $\mathrm{HRT}$, $[\mathrm{TOC}]_{\mathrm{in}}=\mathbf{4 4 . 8 3} \mathrm{mg} / \mathrm{L}$. 
$\mathrm{H}_{2} \mathrm{O}_{2}$ concentration of $750 \mathrm{mg} / \mathrm{L}$. The elevation of AOS implies that the intermediates which are formed during the treatment are oxidized easier (Sarria et al., 2002). Constant AOS after 120 min HRT means that the chemistry of the produced intermediates does not change notably after that time.

BOD $/$ COD ratio of the SPWW was also improved by increasing HRT during the UV/US/ $/ \mathrm{H}_{2} \mathrm{O}_{2}$ process. Applying HRT of $120 \mathrm{~min}$ in all the experiment expect the one with initial oxidant concentration of $500 \mathrm{mg} / \mathrm{L}$ made the $\mathrm{BOD}_{5} / \mathrm{COD}$ ratio cross 0.4 which means the wastewater samples could be considered biodegradable. However, samples with higher initial concentration of the oxidant became biodegradable in lower hydraulic retention times.

\subsubsection{Residual $\mathrm{H}_{2} \mathrm{O}_{2}$ concentration profile}

As mentioned in the Section 4.5.1, high concentrations of $\mathrm{H}_{2} \mathrm{O}_{2}$ affect the performance of bacterial communities negatively. In many studies concerning application of $\mathrm{H}_{2} \mathrm{O}_{2}$ based AOPs prior to biological treatment; the residual $\mathrm{H}_{2} \mathrm{O}_{2}$ was removed or neutralized from the wastewater before introducing it to bioreactor. Several components are used to remove $\mathrm{H}_{2} \mathrm{O}_{2}$. The most common is known as catalase enzyme (Tabrizi and Mehrvar, 2004; Badawy et al., 2009; Barrera, 2011; Vilar et al., 2012). Sodium sulfite was also used (Adam et al., 1994). Continually addition of catalase to the wastewater, especially in the industrial scale, would increase the treatment cost significantly. In order to avoid using catalase, the residual concentration of hydrogen peroxide should be minimized in the effluent of AOP reactor. This may achieve whether by decreasing the initial dosage of the oxidant or increasing the hydraulic retention time. 


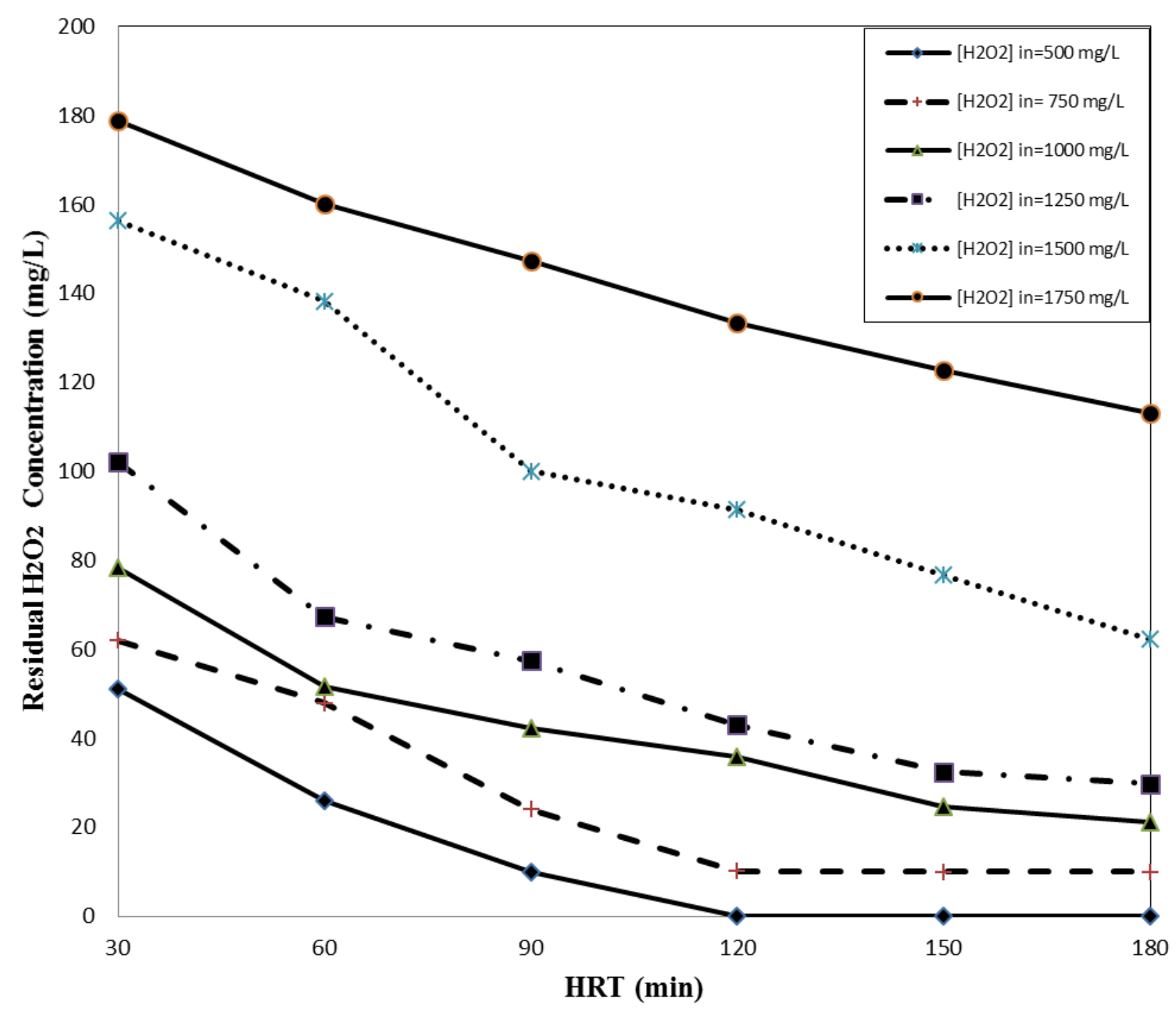

Figure 4.18. Residual $\mathrm{H}_{2} \mathrm{O}_{2}$ concentration in the effluent of the sonophotoreactor at various HRT, $[\text { TOC }]_{\text {in }}=44.83 \mathrm{mg} / \mathrm{L}$. 
Figure 4.20 illustrates the residual $\mathrm{H}_{2} \mathrm{O}_{2}$ concentration under $\mathrm{UV} / \mathrm{US} / \mathrm{H}_{2} \mathrm{O}_{2}$ process at various hydraulic retention times. The trend of residual oxidant concentration is approximately the same for all experiments. Reducing the inlet dosage of hydrogen peroxide caused lower residual concentration in the effluent.

Using the optimum dosage of the oxidant found in Section $4.3 .2(1750 \mathrm{mg} / \mathrm{L})$ results in more than 130 and $110 \mathrm{mg} / \mathrm{L} \mathrm{H}_{2} \mathrm{O}_{2}$ in the effluent of sonophotoreactor after 120 and $180 \mathrm{~min} \mathrm{HRT}$, respectively. In the case of inlet $\mathrm{H}_{2} \mathrm{O}_{2}$ concentrations of 750 and $500 \mathrm{mg} / \mathrm{L}$, in the experiments with HRT of $120 \mathrm{~min}$ and more, less than $11 \mathrm{mg} / \mathrm{L} \mathrm{H}_{2} \mathrm{O}_{2}$ in the effluent were observed. This low concentration caused in a low efficiency of the treatment which can be seen in TOC removal curve (Figure 4.16). Therefore, it seems that there is no need for retention times higher than 120 min while working with 500 and $750 \mathrm{mg} / \mathrm{L} \mathrm{H}_{2} \mathrm{O}_{2}$.

It has been mentioned in the open literature that very low concentrations of $\mathrm{H}_{2} \mathrm{O}_{2}$ does not cause drastic problems on microorganisms applied in biological treatment (Oller et al., 2011; Scott and Ollis, 1995). Also, Laera et al. (2012) reported that $\mathrm{H}_{2} \mathrm{O}_{2}$ in low range of $3-7 \mathrm{mg} / \mathrm{L}$ did not influence the membrane bioreactor biomass while integrated with the $\mathrm{UV} / \mathrm{H}_{2} \mathrm{O}_{2}$ process. These findings would be useful to determine the stage that the wastewater samples could be transferred from the sonophotoreactor to the aerobic AS process. 


\subsubsection{Determination of optimum $\mathrm{H}_{2} \mathrm{O}_{2}$ dosage and hydraulic retention time for combination of the $\mathrm{UV} / \mathrm{US} / \mathrm{H}_{2} \mathrm{O}_{2}$ and the aerobic $\mathrm{AS}$ processes}

Biodegradability studies demonstrated that except the experiment with inlet oxidant dosage of $500 \mathrm{mg} / \mathrm{L}$, using $120 \mathrm{~min}$ retention time, make the wastewater biodegradable and significant efficiency from aerobic AS process could be expected.

Additionally, considering residual $\mathrm{H}_{2} \mathrm{O}_{2}$ profile and data found in the open literature regarding the tolerance of microorganisms to $\mathrm{H}_{2} \mathrm{O}_{2}$, it seems that only effluents from experiments with of inlet $\mathrm{H}_{2} \mathrm{O}_{2}$ concentrations of 750 and $500 \mathrm{mg} / \mathrm{L}$ with retention times more than 120 min could be transferred to the bioreactor without having adverse effect on microorganisms. Since experiments with $500 \mathrm{mg} / \mathrm{L}$ oxidant did not yield acceptable TOC removal, $750 \mathrm{mg} / \mathrm{L}_{2} \mathrm{O}_{2}$ was chosen for combined experiments. Also hydraulic retention time of 120 min was selected due to limited residual $\mathrm{H}_{2} \mathrm{O}_{2}$ and satisfactory $\mathrm{BOD}_{5} / \mathrm{COD}$ ratio.

For the aerobic AS process, according to experiments in Section 4.4, HRT of $24 \mathrm{~h}$ was chosen for combined processes.

\subsubsection{Combined Processes}

Combining AOPs and biological systems seems as a great alternative to achieve high treatment ability along with lower cost. Therefore, several researchers have used this treatment method for elimination of various types of pollutants from aqueous solutions. In 2003, Entezari and Petrier combined sonolysis process with enzymatic treatment in order to degrade substituted phenols in water. They observed higher removal efficiency in the combined method comparing to the two 
processes individually. Sirtori et al. (2009) combined photo-Fenton and immobilized biomass reactor (IBR) to treat a pharmaceutical wastewater containing an antibiotic named nalidixic acid. The antibiotic concentration remained unchanged after the bio treatment. Photo-Fenton process was applied as pre-treatment and used till the antibiotic was removed completely. The combined process reduced the dissolved organic carbon by $95 \%$. In another recent study, treatment of an antibiotic wastewater containing amoxicillin and cloxillin was studied by applying Fenton and TiO2 photocatalysis prior to a sequencing biological batch reactor (Elmolla and Chaudhuri, 2011 and 2012). Fenton and photocatalysis were able to remove the antibiotics completely after 1 and 30 min, respectively. Also, COD removal in combination processes using Fenton was 89\% which was much better than $57 \%$ that was achieved using photocatalysis as pretreatment. The mentioned studies are few examples that confirm the treat ability and capability of the combined methods.

In the final step of this study, the SPWW with TOC loading of $44.83 \mathrm{mg} / \mathrm{L}$ was first treated under the UV/US/ $\mathrm{H}_{2} \mathrm{O}_{2}$ process under HRT of $120 \mathrm{~min}$. The inlet $\mathrm{H}_{2} \mathrm{O}_{2}$ concentration was $750 \mathrm{mg} / \mathrm{L}$. Other operational parameters were adjusted to the optimum values which were found in batch experiments $(\mathrm{pH}=2$, US power $=140 \mathrm{~W}$, air flow rate $=3 \mathrm{~L} / \mathrm{min})$. The effluent was collected and before introducing to the aerobic AS reactor, the $\mathrm{pH}$ was adjusted to 7 using $\mathrm{NaOH}$ solution. After $\mathrm{pH}$ adjustment, the pre-treated wastewater was transferred to the bioreactor and the flow rate was adjusted to have $24 \mathrm{~h}$ retention time. The results are shown in figures 21 . The TOC and COD removal were $98 \%$ and $99 \%$, respectively. The combined processes were successful in treatment of the SPWW. The molar ratio of $\left[\mathrm{H}_{2} \mathrm{O}_{2}\right] /[\mathrm{TOC}]$ in the combined processes were 5.9 which showed a significant reduction comparing to the optimum value found in UV/US/ $/ \mathrm{H}_{2} \mathrm{O}_{2}$ process alone. From the $98 \%$ TOC removal, about $31 \%$ was due to the advanced oxidation 
process and the rest was attributed to the aerobic AS process. In the case of COD reduction, $43.5 \%$ was eliminated in the sonophotoreactor and $55.5 \%$ was deducted in the bioreactor. The results confirm that combination of advanced oxidation and aerobic AS process could contribute to high treatment efficiency and reduce the chemical dosage consumption.

Almost all of the TN removal was occurred in the aerobic AS process. However, higher TN removal was achieved in the combined processes comparing to the aerobic AS process alone. This may be due to change in the structure of nitrogenous compounds. The results confirm that the combination of advanced oxidation and aerobic AS process could contribute to a high treatment efficiency and reduce the chemical dosage consumption. 


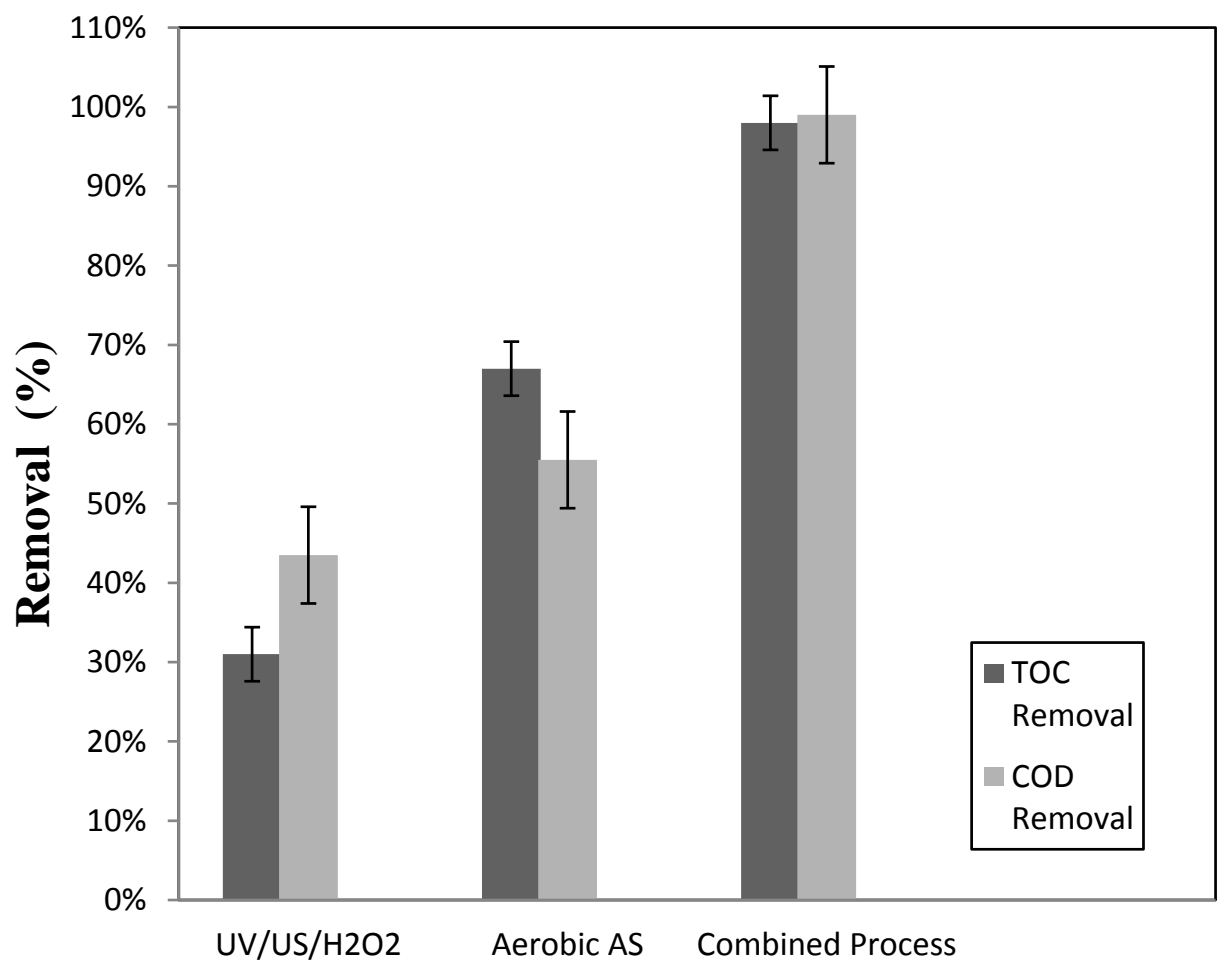

Figure 4.19. Comparison of TOC and COD removal using different alternatives in continuous mode without recycling, including $\mathrm{UV} / \mathrm{US} / \mathrm{H}_{2} \mathrm{O}_{2}$ process alone in continuous mode, aerobic $\mathrm{AS}$ process alone in continuous mode and combination of both processes $\left([\mathrm{TOC}]_{\mathrm{in}}=44.83 \mathrm{mg} / \mathrm{L}\right.$, $[\mathrm{COD}]_{\mathrm{in}}=127 \mathrm{mg} / \mathrm{L}$, air flow rate in sonophotoreactor $=2 \mathrm{~L} / \mathrm{min}, \mathrm{pH}=2,\left[\mathrm{H}_{2} \mathrm{O}_{2}\right]_{\mathrm{in}}=750 \mathrm{mg} / \mathrm{L}, \mathrm{HRT}$ in sonophotoreactot $=120 \mathrm{~min}, \mathrm{HRT}$ in bioreactor $=24 \mathrm{~h}$ ) 


\section{CHAPTER 5}

\section{CONCLUSIONS AND RECOMMENDATIONS}

\subsection{Conclusions}

From the conducted experiments and obtained results, following conclusions could be drawn:

- Efficiency of seven different processes of $\mathrm{H}_{2} \mathrm{O}_{2}$ alone, sonolysis (US alone), photolysis (UV alone), UV/US, $\mathrm{UV} / \mathrm{H}_{2} \mathrm{O}_{2}, \mathrm{US} / \mathrm{H}_{2} \mathrm{O}_{2}$ and $\mathrm{UV} / \mathrm{US} / \mathrm{H}_{2} \mathrm{O}_{2}$ were investigated for treatment of a pharmaceutical wastewater. It was found that the highest TOC removal achieved through $\mathrm{UV} / \mathrm{US} / \mathrm{H}_{2} \mathrm{O}_{2}$ process. The second best process was $\mathrm{UV} / \mathrm{H}_{2} \mathrm{O}_{2}$ process. The other methods resulted in less than $10 \%$ TOC removal after 150 min reaction time.

- $\mathrm{H}_{2} \mathrm{O}_{2}$ alone process lead to the lowest TOC removal. However, the addition of $\mathrm{H}_{2} \mathrm{O}_{2}$ to US, UV and US/UV processes improved the TOC removal by $2 \%, 28 \%$ and $36 \%$, respectively after 90 min reaction time.

- Batch recirculation mode experiments were performed to determine the optimum operational parameters. Ultrasonic power of $140 \mathrm{~W}$, initial $\mathrm{pH}$ solution of 2 and airflow rate of $3 \mathrm{~L} / \mathrm{min}$ were found as optimal values. Also, in the case of $\mathrm{H}_{2} \mathrm{O}_{2}$ concentration, $1750 \mathrm{mg} / \mathrm{L}$ for the wastewater with initial $\mathrm{TOC}$ of $44.83 \mathrm{mg} / \mathrm{L}$ resulted in highest degradation. For the other two wastewater samples with TOC of 89.75 and $179.33 \mathrm{mg} / \mathrm{L}$, 
$2250 \mathrm{mg} / \mathrm{L}$ of the oxidant was optimum. These results contributed to $\left[\mathrm{H}_{2} \mathrm{O}_{2}\right] /[\mathrm{TOC}]$ molar ratio of $13.77,8.85$ and 4.42 , respectively.

- The addition of $\mathrm{H}_{2} \mathrm{O}_{2}$ more than optimum dosage decreased the efficiency of the treatment and increased the operating cost. Therefore, in all the advanced oxidation processes that $\mathrm{H}_{2} \mathrm{O}_{2}$ is used, the optimum dosage should be determined carefully.

- Continuous mode experiments were performed using the optimum operating conditions. Hydraulic retention times between 30 and 180 min were used. The $\mathrm{UV} / \mathrm{US} / \mathrm{H}_{2} \mathrm{O}_{2}$ process led to more than $90 \%$ removal under 180 min HRT. This proved the high treatment ability of the process. However, the high chemical dosage and the high electrical power consumption are the problems associated with AOPs which should be considered while their application in industrial scale

- Aerobic activated sludge process in a laboratory scale reactor was also employed to treat the SPWW with different inlet TOC and COD loadings. The process was able to remove the TOC in the range of 65 to $73 \%$ and COD in the range 61 to $80 \%$ under $24 \mathrm{~h}$ hydraulic retention time. Increasing the HRT to $48 \mathrm{~h}$ did not make significant change on the efficiency of the treatment. The ability of biological process to treat the SPWW was not sufficient since more than $95 \%$ removal in TOC is required. Due to this fact, the application of AOPs as pre-treatment to make the wastewater sample more biodegradable looks indispensible.

- During the $\mathrm{UV} / \mathrm{US} / \mathrm{H}_{2} \mathrm{O}_{2}$ process in continuous mode, biodegradability studies were performed based on the evolution of $\mathrm{BOD}_{5} / \mathrm{COD}$ ratio and average oxidation state of the 
effluents. Except the experiment with inlet oxidant concentration of $500 \mathrm{mg} / \mathrm{L}$, $\mathrm{BOD}_{5} / \mathrm{COD}$ ratio passed over 0.4 after $120 \mathrm{~min}$ retention time. This implies that the effluent of the sonophotoreactor could be considered biodegradable. Additionally, the AOS was also increased from -0.16 to 1.3 . The enhancement of AOS reveals that the produced intermediates could be oxidized easier.

- It has been mentioned that high concentrations of $\mathrm{H}_{2} \mathrm{O}_{2}$ inhibits bacterial activity. However, very low concentrations do not cause serious troubles. Due to the importance of this issue, residual $\mathrm{H}_{2} \mathrm{O}_{2}$ concentration in the effluent of the sonophotoreactor was determined using DMP method. In the experiments with inlet $\mathrm{H}_{2} \mathrm{O}_{2}$ concentration of 500 and $750 \mathrm{mg} / \mathrm{L}$, less than $11 \mathrm{mg} / \mathrm{L}$ of the oxidant was determined in the effluents with more than $120 \mathrm{~min}$ HRT. According to the data found in the open literature, this low concentration can be introduced to the biological process without affecting microorganism negatively.

- $\quad$ Based on the data from biodegradability studies and also those from $\mathrm{H}_{2} \mathrm{O}_{2}$ concentration profile, $750 \mathrm{mg} / \mathrm{L}$ of the oxidant was selected to be used in combined processes. Hydraulic retention time in the sonophotoreactor and bioreactor was selected as $120 \mathrm{~min}$ and $24 \mathrm{~h}$, respectively.

- In the combined processes, the SPWW was pretreated in the sonophotoreactor using the optimum operational parameters and $750 \mathrm{mg} / \mathrm{L} \mathrm{H}_{2} \mathrm{O}_{2}$. The effluent was collected and after $\mathrm{pH}$ adjustment, it was transferred to the bioreactor. Combination of the UV/US/ $\mathrm{H}_{2} \mathrm{O}_{2}$ and aerobic AS process was able to treat the SPWW successfully. Over 98\% TOC and 99\% COD removal were observed. The results confirmed the high treatment ability of the 
combined processes. The consumption of the oxidant was also reduced in combined process. Molar ratio of $\left[\mathrm{H}_{2} \mathrm{O}_{2}\right] /[\mathrm{TOC}]$ used in the combined process was 5.9 which is significantly lower than 13.77 that was found for the UV/US/ $\mathrm{H}_{2} \mathrm{O}_{2}$ alone.

\subsection{Recommendations}

The following recommendations are proposed for future studies:

- In order to improve the degradation efficiency in UV/US process and enhance the synergic effect, using ultrasonic probes with higher frequencies and higher output powers are recommended.

- $\quad$ Future studies may consider application of UV lamps with different fluencies to evaluate the effect of intensity of UV light on degradation.

- Future study should focus on the effect of the addition of catalysts such as $\mathrm{TiO}_{2}, \mathrm{ZnO}_{2}$ to the US/UV process while combining with biological processes.

- Further studies should apply actual raw pharmaceutical wastewater in order to evaluate the applicability of the systems examined in these studies to actual conditions, and determine a possible scale up of laboratory scale systems.

- Further work should be considered investigation on the kinetic modeling, optimization of processes, and modeling of the combined $\mathrm{UV} / \mathrm{US} / \mathrm{H}_{2} \mathrm{O}_{2}$ and aerobic AS processes.

- Future research should consider different patterns for addition of addition of $\mathrm{H}_{2} \mathrm{O}_{2}$ to $\mathrm{AOP}$ reactor instead of initial injection. 


\section{References}

Acero, J.L, Benitez, F.J., Real, F.J., Roldan, G. "Kinetics of aqueous chlorination of some pharmaceuticals and their elimination from water matrices." Water Res. 44 (2010): 41584170.

Adams, C. D., Scanlon, P. A., Secrist, N. D. "Oxidation and biodegradability enhancement of 1,4Dioxane using hydrogen peroxide and ozone." Environ. Sci.Technol. 28, no. 11 (1994): 1812-1888.

Aga., D.S. Fate of Pharmaceuticals in the Environment and in Water Treatment, First edition. London, Newyork: Taylor Francis Group, 2008.

Ahmedchekkat, F., Medjram, M.S., Chiha, M., Al-Bsoul, A.M.A. "Sonophotocatalytic degradation of Rhodamine B using a novel reactor geometry: Effect of operating conditions." Chem. Eng. J. 178 (2011): 244-251.

Akiyama, T., Savin, M.C. "Populations of antibiotic-resistant coliform bacteria change rapidly in a wastewater effluent dominated stream." Sci. Total Environ. 408, no. 24 (2010): 61926201.

Alaton., I.A., Dogruel, S., Baykal, E., Gerone, G. "Combined chemical and biological oxidation of peniciline formulation efflent." J. Environ. Manage. 73 (2004): 155-163.

Alum, A., Yoon, Y., Westerhoff, P., Abbaszadegan, M. "Oxidation of bisphenol A, 17-betaestradiol, and 17-alphaethynyl estradiol and byproduct estrogenicity." Environ. Toxicol. 19, no. 3 (2004): 257-264. 
Antouniou, P., Hamilton, J., Koopman, B., Holloway, B., Lyberatos, G., Svoronos, S.A. "Effect of temperature and $\mathrm{pH}$ on the effective maxiumum specific growth rate of nitrifying bacteria." Water Res. 24, no. 1 (1990): 97-101.

APHA. Standards Methods for the Examination of Water and Wastewater. Washington D.C: American Water Association, Water Environment Federation, 1998.

Arslan, I., Balcioglu, A.I. "Degradation of Remazol black B dye and its simulated dyebath wastewater by advanced oxidation processes in heterogeneous and homogenous media." Color Technol. 117, no. 1 (2001): 38-42.

Asano, T., Burton, F, and Leverenz, H. Water Reuse: Issues, Technologies, and Applications. . New York: McGraw-Hill Professional, 2007.

Augugliaro, V., Litter, M., Palmisano, L., Soria, J. "The combination of heterogeneous photocatalysis with chemical and physical operations: A tool for improving the photoprocess performance ." J. Photoch. Photobio. C 7, no. 4 (2006): 127-144.

Battimelli, A., Loisel, D., Garcia-Bernet, D., Carrere, H., Delgenes, J.-P. "Combined ozone pretreatment and biological processes for removal of colored and biorefractory compounds in wastewater from molasses fermentation industries." J. Chem. Technol. Biotechnol. 85, no. 7 (2010): 968-975.

Badawy, M.I., Wahaab, R.A., El-Kalliny, A.S. "Removal of veterinary antibiotics from sequencing batch reactor (SBR) pretreated swine wastewater by Fenton's reagent." $J$. Hazard. Mater. 167, no. 1-3 (2009): 567-574.

Barrera, M. "Photochemical treatment of organic constituents and bacterial pathogens from synthetic slaughterhouse wastewater by combining Vacuum-UV and UV-C." MASc Thesis, Toronto; Ryerson University, 2011. 
Ben, W., Qiang, Z., Pan, X., Chen, M. "Fenton-biological treatment processes for the removal of some pharmaceuticals from industrial wastewater." Water Res. 43, no. 17 (2009): 43924402.

Behnajady, M.A., Modirshahla, N., Shokri, M., Vahid, B. "Effect of operational parameters on degradation of Malachite Green by ultrasonic irradiation." Ultrason. Sonochem. 15, no. 6 (2008): 1009-1014.

Bernhard, M., Müller, J., Knepper, T.P. "Biodegradation of persistent polar pollutants in wastewater: comparison of an optimized lab-scale membrane bioreactor and activated sludge treatment." Water Res. 40 (2006): 3419-3428.

Bolong, N., Ismail, A.F., Salim, M.R., Matsuura, T. "Review of the effects of emerging contaminants in wastewaters and options for their removal." Desalination 239 (2009): 229-246.

Bolton, J., and Cotton, C. The Ultraviolet Disinfection Handbook (1st ed.). Denver: American Water Works Association (AWWA), 2008.

Bolton, J.R. Ultraviolet Application Handbook (3rd ed.). Edmonton: Bolton Photosciences Inc., 2010.

Braghetta, A., Brownawell, B. "Removal of pharmaceuticals and endocrine disrupting compounds through advanced wastewater treatment technologies." AWWA - Water Quality Technology Conference. 2002.

Braun, A.M. and Oliveros, E. "How to evaluate photochemical methods for water treatment." Water Sci. Tech. 35, no. 4 (1997): 17-23. 
Bredhult, C., Bäcklin B.M., Olovsson, M. "Effects of some endocrine disruptors on the proliferation and viability of human endometrial endothelial cells in vitro." Reprod. Toxicol. 23 (2007): 550-559.

Brown, K.D., Kulis, J., Thomson, B., Chapman, T.H., Mawhinney, D.B. "Occurrence of antibiotics in hospital, residential, and dairy effluent, municipal wastewater, and the Rio Grande in New Mexico." Sci. Total Environ. 366 (2006): 772-783.

Bustillo-Lecompte, C. "Combined anaerobic-aeribic and UV/H2O2 proceeses for the treatment of synthetic slaughterhouse wastewater." MASc Thesis, Toronto; Ryerson University, 2012.

Bustillo-Lecompte, C., Mehrvar, M., Quninones-Bola, E. "Combined anaerobic-aerobic and $\mathrm{UV} / \mathrm{H} 2 \mathrm{O} 2$ processes for the treatment of synthetic slaughterhouse wastewater." $J$. Environ. Sci. Health, A 48 (2013): 1112-1135.

Cao, W., and Mehrvar, M. "Slaughterhouse wastewater treatment by combined anaerobic baffled reactor and UV/H2O2 processes." Chem. Eng. Res. Des., 89 (7), 1136-1143.

Carballa, M., Manterola, G., Larrea, L., Ternes, T., Omil, F., Lema, J.M. "Influence of ozone pretreatment on sludge anaerobic digestion: Removal of pharmaceutical and personal care products." Chemosphere 67, no. 7 (2007): 1444-1452.

Chan, Y.J., Chong, M.F., Law, C.L., Hassell, D.G. "A review on anaerobic-aerobic treatment of industrial and municipal wastewater." Chem. Eng. J. 155, no. 1-2 (2009): 1-18.

Chang, C., Chang, J., Vigneswaran, S., Kandasamy, J. "Pharmaceutical wastewater treatment by membrane bioreactor process- a case study in southern Taiwan." Desalination 234, no. 1-3 (2008): 386-392. 
Chen, Y.F. , Ng, W.J. , Yap, M.G.S. "Performance of upflow anaerobic biofilter process in pharmaceutical wastewater treatment." Resour. Conserv. Recycl. 11, no. 1-4 (1994): 7381.

Chen, Z., Ren, N., Wang, A., Zhang, Z., Shi, Y. "A novel application of TPAD-MBR system to the pilot treatment of chemical synthesis-based pharmaceutical wastewater." Wat. Res. 42 (2008): 3385-3392.

Chisiti, M.Y., Halard., B., Moo-Young, M. "Liquid circulation in airlift reactors." Chem. Eng. Sci. 43, no. 3 (1988): 451-457.

Choi, K., Kim, Y., Park, J., Park, C.K., Kim, M., Kim, H.S., Kim, P. "Seasonal variations of several pharmaceutical residues in surface water and sewage treatment plants of Han River, Korea." Sci. Total Environ. 405, no. 1-3 (2008): 120-128.

Comninellis, C., Kapalka, A., Malato, S., Parsons, S.A., Poulios, I., Mantzavinos, D. "Contribution of the ozonation pre-treatment to the biodegradation of aqueous solutions of 2,4-dichlorophenol" Water Res. 37, no. 13 (2003): 3164-3171.

Contreras, S., Rodríguez, M., Al Momani, F., Sans, C., Esplugas, S. "Advanced oxidation processes for water treatment: Advances and trends for R\&D." J. Chem. Technol. Biotechnol. 83, no. 6 (2008): 769-776.

De la Cruz, N., Giménez, J., Esplugas, S., Grandjean, D., De Alencastro, L.F., Pulgarín, C. "Degradation of 32 emergent contaminants by UV and neutral photo-fenton in domestic wastewater effluent previously treated by activated sludge." Water Res. 46, no. 6 (2012): 1947-1957. 
Deegan, A.M., Shaik, B., Nolan, K., Urell, K., Oelgemöller, M., Tobin, J., Morrissey, A. "Treatment options for wastewater effluents from pharmaceutical companies." Int. J. Environ. Sci. Technol. 8, no. 3 (2011): 649-666.

Destaillats, H., A.J. Colussi, J.M. Joseph, and M.R. Hoffmann. "Synergistic effects of sonolysis." J. Phys. Chem. 104, no. 39 (2000): 8930-8935.

Durán, A., Monteagudo,J.M., Sanmartín, I., Gómez, P. "Homogeneous sonophotolysis of food processing industry wastewater: Study of synergistic effects, mineralization and toxicity removal." Ultrason. Sonochem. 20 (2013): 785-791.

Ecenfelder, W. Industrial Water Pollution Control. New York: McGraw Hill, 2000.

Edalatmanesh, M., Mehrvar, M., Dhib, R. "Optimization of phenol degradation in a combined photochemical-biological wastewater treatment system." Chem. Eng. Res. Des. 86, no. 11 (2008): 1243-1252.

El Gohary, F., Abou-Elea, S. "Evaluation of biological technologies for wastewater treatment in the pharmaceutical industry." Water Sci. Tech. 32, no. 11 (1995): 13-20.

Elmolla, E.S., Chaudhuri, M. "The feasibility of using combined Fenton-SBR for antibiotic wastewater treatment." Desalination 285 (2012): 14-21.

Elmolla, E.S., Chaudhuri, M. "The feasibility of using combined TiO2 photocatalysis-SBR process for antibiotic wastewater treatment." Desalination 272, no. 1-3 (2011): 218-224.

Emery, R.J., Papadaki, M., Freitas Dos Santos, L.M., Mantzavinos, D. "Extent of sonochemical degradation and change of toxicity of a pharmaceutical precursor (triphenylphosphine oxide) in water as a function of treatment conditions." Environ. Int. 31, no. 2 (2005): 207211. 
Emmanuel, E. Evaluation des risques sanitaires et ecotoxicologiques lies aux effluents hospitaliers; Ph.D. Dissertation. Lyon: Institut National des Science Appliquées, 2004.

Enright, A., McHugh, S., Collins, G., O’Flaherty, V. "Low-temperature anaerobic biological treatment of solvent containing pharmaceutical wastewater." Water Res. 39, no. 19 (2005): $4587-4596$.

Entezari, M.H., Petrier, C., Devidal, P. "Sonochemical degradation of phenol in water: a comparison of classical equipment with a new cylindrical reactor." Ultrason. Sonochem. 10 (2003): 103-108.

Environment Canada. (2000). Framework and recommendations concerning effluent quality of wastewater disposed by federal institutions. Retrieved December 10, 2010, from FCEMS/Wastewater Working Group: http://www.csc-scc.gc.ca/text/plcy/doc/318-6gl_e.pdf. n.d.

EPA, (1997) Office of Compliance Sector Notebook Project: Profile of Pharmaceutical Manufacturing Industry, 310-R-97-005.

EPA, U.S. (1998) Development Document for Final Efflent Limitations Guidlines and Standards for the Pharmaceutical Manufacturing Point Source Category. Washington: U.S. Environmental Protection Agency.

Gao, Y.-Q., Gao, N.-Y., Deng, Y., Gu, J.-S., Gu, Y.-L., Zhang, D. "Factors affecting sonolytic degradation of sulfamethazine in water. "Ultrason. Sonochem. 26, no. 6 (2013): 14011407.

Ghafoori, S., Mehrvar, M., Chan, P.K., "Photoassisted Fenton-like degradation of aqueous poly(acrylic acid): From mechanistic kinetic model to CFD modeling. " Chem. Eng. Res. Des. (2013), http://dx.doi.org/10.1016/j.cherd.2013.05.019. 
Gebhardt, W., Schröder, H.F., "Liquid chromatography-(tandem) mass spectrometry for the follow-up of the elimination of persistent pharmaceuticals during wastewater treatment applying biological wastewater treatment and advanced oxidation." J. Chromatogr. A 1160, no. 1-2 (2007): 34-43.

Göbel A., Thomsen A., McArdell C.S., Joss A., Giger W. "Occurrence and sorption behavior of sulfonamides, macrolides, and trimethoprim in activated sludge treatment." Environ. Sci. Technol. 39 ( 2005): 3981-3989.

Gogate, P.R., Pandit, A.B. "A review of imperative technologies for wastewater treatment I: Oxidation technologies at ambient conditions." Adv. Environ. Res. 8, no. 3-4 (2004): 501551.

Gómez, J.L., León, G., Hidalgo, A.M., Gómez, M., Murcia, M.D., Griñán, G. "Application of reverse osmosis to remove aniline from wastewater." Desalination 245, no. 1-3 (2009): 687-693.

Grady, C. P., Daigger, G. T., and Lim, H. C. Biological Wastewater Treatment, second ed. revised and expanded. NewYork: Marcel Dekker Inc., 1999.

Gulyas, H. "Processes for the removal of recalcitrant organics from industrial wastewaters." Water Sci. Technol. 36, no. 2-3 (1997): 9-16.

Gunnarsson, L., Kristiansson, E., Rutgersson, C., Sturve, J., Fick, J., Förlin, L., Larsson, D.G.J. "Pharmaceutical industry effluent diluted 1:500 affects global gene expression, cytochrome P450 1A activity, and plasma phosphate in fish." Environ. Toxicol. Chem. 28, no. 12 (2009): 2639-2647. 
Gupta, S., Gupta, S., Hung, Y.T. "Treatment of Pharmaceutical Wastes." In Handbook of Industrial and Hazardous Wastes Treatment, 63-130. NewYork: Marcel Dekker, Inc., 2004.

Guyer, G.T., Ince, N.H. "Degradation of diclofenac in water by homogeneous and heterogeneous sonolysis." Ultrason. Sonochem. 18 (2011): 114-119.

Haji, S., Benstaali, B., Al-Bastaki, N. "Degradation of methyl orange by UV/H2O2 advanced oxidation process." Chem. Eng. J. 168 (2011): 134-139.

Hamdaoui, O., Naffrechoux, E. " Sonochemical and photosonochemical degradation of 4chlorophenol in aqueous media" Ultrason. Sonochem. 15, no. 6 (2008): 981-987.

Hapeshi, E., Fotiou, I., Fatta-Kassinos, D. "Sonophotocatalytic treatment of ofloxacin in secondary treated effluent and elucidation of its transformation products." Chem. Eng. J. 224 (2013): 96-105.

Hartmann, J., Bartels, P., Mau, U., Witter, M., Tümpling, W.v., Hofmann, J., Nietzschmann, E. "Degradation of the drug diclofenac in water by sonolysis in presence of catalysts." Chemosphere 70, no. 3 (2008): 453-461.

He, Y., Bishop, P.L. "Effect of acid orange 7 on nitrification process." J. Environ. Eng. 120, no. 1 (1994): 108-121.

He, Z., Zhu, R., Xu, X., Song, S., Chen, J., Xia, M. "Ozonation combined with sonolysis for degradation and detoxification of m-nitrotoluene in aqueous solution." Ind. Eng. Chem. Res. 48, no. 12 (2009): 5578-5583.

Hua, I., Hoffman, M.R. "Optimization of ultrasonic irradiation as an advanced oxidation technology." Environ. Sci. Technol. 31 (1997): 2237-2243. 
Huerta-Fontela, M., Galceran, M.T., Ventura, F. "Occurrence and removal of pharmaceuticals and hormones through drinking water treatment." Water Res. 45, no. 3 (2011): 1432-1442.

Ileri, R., Sengil, I., Kulac, S., Damar, Y. "Treatment of mixed pharmaceutical industry and domestic wastewater by sequencing batch reactor." J. Environ. Sci. Health. A. 38, no. 10 (2003): 2101-2111.

Isariebel, Q.P., Carine, J.L., Ulises-Javier, J.H., Marie, W.A., Henri, D. "Sonolysis of levodopa and paracetamol in aqueous solutions." Ultrason. Sonochem. 16 (2009): 610-616.

Jagannathana, M., Grieser, F., Ashokkumar, M. "Sonophotocatalytic degradation of paracetamol using TiO2 and $\mathrm{Fe}^{3+} . "$ Sep. Purif. Technol. 103 (2013): 114-118.

Ji, J.Y., Xing, Y.J., Ma, Z.T., Cai, J., Zheng, P., Lu, H.F. "Toxicity assessment of anaerobic digestion intermediates and antibiotics in pharmaceutical wastewater by luminescent bacterium." J. Hazard. Mater. 246-247 (2013): 319-323.

Jones, O. A. H., Voulvoulis, N., Lester, J.N. "Potential ecological and human health risks associated with the presence of pharmaceutically active compounds in the aquatic environment." Crit. Rev. Toxicol. 34, no. 4 (2004): 335-350.

Joseph, C.G., Li Puma, G., Bono, A., Krishnaiah, D. "Sonophotocatalysis in advanced oxidation process: A short review." Ultrason. Sonochem. 16, no. 5 (2009): 583-589.

Kasprzyk-Hordern, B., Dinsdale, R.M., Guwy, A.J. "The occurrence of pharmaceuticals, personal care products, endocrine disruptors and illicit drugs in surface water in South Wales, UK." Water Res. 42 (2008): 3498-3518.

Khetan, S., Collins, T. "Human pharmaceuticals in the aquatic environment: A challenge to green chemistry." Chem. Rev. 107, no. 6 (2007): 2319-1364. 
Khokhawala, I.M., Gogate, P.R. "Degradation of phenol using a combination of ultrasonic and UV irradiations." Ultrason. Sonochem. 17 (2010): 833-838.

Kidak, R., Ince, N.H. " Catalysis of advanced oxidation reactions by ultrasound: A case study with phenol." J. Adv. Oxid. Technol. 146, no. 3 (2007):630-635.

Kim, I., Yamashita, N., Tanaka, H. "Performance of UV and UV/H2O2 processes for the removal of pharmaceuticals detected in secondary effluent of a sewage treatment plant in Japan." $J$. Hazard. Mater. 166, no. 2-3 (2009): 1134-1140.

Kimura, K., Hara, H., Watanabe, Y. "Elimination of selected acidic pharmaceuticals from municipal wastewaters by activated sludge systems and membrane bioreactors." Environ. Sci. Technol. 41 (2007): 3708-3714 .

Klamerth, N., Malato, S., Maldonado, M.I., Agüera, A., Fernández-Alba, A. "Modified photoFenton for degradation of emerging contaminants in municipal wastewater effluents." Catal. Today 161, no. 1 (2011): 241-246.

Klamerth, N., Rizzo, L., Malato, S., Maldonado, M.I., Agüera, A., Fernández-Alba, A.R. "Degradation of fifteen emerging contaminants at $\mu \mathrm{g}$ L-1 initial concentrations by mild solar photo-Fenton in MWTP effluents." Water Res. 44, no. 2 (2010): 545-554.

Klavarioti, M., Mantzavinos, D., Kassinos, D. "Removal of residual pharmaceuticals from aqueous systems by advanced oxidation processes." Environ. Int. 35 (2009): 402-417.

Köhler, C., Venditti, S., Igos, E., Klepiszewski, K., Benetto, E., Cornelissen, A. "Elimination of pharmaceutical residues in biologically pre-treated hospital wastewater using advanced UV irradiation technology: A comparative assessment." J. Hazard. Mater. 239-240 (2012): 70-77. 
Korenaga, T., Zhou, X., Okada, K., Monwake, T. "Determination of chemical oxygen demand by a flow-injection method using cerium(IV) sulphate as oxidizing agent." Anal. Chim. Acta 272, no. 2 (1993): 237-244.

Kosaka, K., Yamada, H., Matsui., S., Echigo., S., Shishida., K. "Comparison among the methods for hydrogen peroxide measurement to evaluate advanced oxidation process; application of spectrophotometric method using Copper(II) ion and 2,9-Dimethyl-1,10phenanthroline." Environ. Sci. Technol. 32 (1998): 3821-3824.

Kosma, C.I., Lambropoulou, D.A., Albanis, T.A. "Occurrence and removal of PPCPs in municipal and hospital wastewater in Greece." J. Hazard. Mater. 179, no. 1-3 (2010): 804817.

Kraigher, B., Kosjek, T., Heath, E., Kompare, B., Mandic-Mulec, I. "Influence of pharmaceutical residues on the structure of activated sludge bacterial communities in wastewater treatment bioreactors." Water. Res. 42, no. 17 (2008): 4578-4588.

Kulik, N., Trapido, M., Goi, A., Veressinina, Y., Munter, R. "Combined chemical treatment of pharmaceutical effluents from medical ointment production." Chemosphere 70, no. 8 (2008): 1525-1531.

Laera, G., Cassano, D., Lopez, A., Pinto, A., Pollice, G., Ricco, G., Mascolo, G. "Removal of organics and degradation products from industrial wastewater by a membrane bioractor integrated with ozone or UV/H2O2 treatment." Environ. Sci. Technol., 46, no.2 (2012): 1010-1018.

Lagarde, F., Tusseau-Vuillemin, M.-H., Lessard, P., Héduit, A., Dutrop, F., Mouchel, J.-M. "Variability estimation of urban wastewater biodegradable fractions by respirometry." Water Res. 39, no. 19 (2005): 34768-4778. 
LaPara, T., Nakatsu, C., Pantea, L., Alleman, J. "Aerobic biological treatment of a pharmaceutical wastewater: Effect of temperature on COD removal and bacterial community development." Water Res. 35, no. 18 (2001): 4417-4425.

Lee, Y., von Gunten, U. "Oxidative transformation of micropollutants during municipal wastewater treatment: Comparison of kinetic aspects of selective (chlorine, chlorine dioxide, ferrateVI, and ozone) and non-selective oxidants (hydroxyl radical)." Water Res. 44, no. 2 (2010): 555-566.

Legrini, O., Dickinson, M. H. "Photochemical processes for water treatment." Chem. Rev. 93 (1993): 671-698.

Lúcia Santos, H.M.L.M., Araújoa, A.N., Fachini, A., Pena, A., Delerue-Matosc, C., Montenegro, M.C.B.S.M. "Ecotoxicological aspects related to the presence of pharmaceuticals in the aquatic environment." J. Hazard. Mater. 175 (2010): 45-95.

Madhavan, J., Grieser, F., Ashokkumar, M. "Combined advanced oxidation processes for the synergistic degradation of ibuprofen in aqueous environments." J. Hazard. Mater. 178, no. 1-3 (2010): 202-208.

Maezawa, A., Nakadoi, H., Suzuki, K., Furusawa, T., Suzuki, Y., Uchida, S. "Treatment of dye wastewater by using photo-catalytic oxidation with sonication." Ultrason. Sonochem. 14, no. 5 (2007): 615-620.

Mannucci, A., Munz, G., Mori, G., Lubello, C. "Anaerobic treatment of vegetable tannery wastewaters: A review." Desalination 264, no. 1-2 (2010): 1-8.

Martins, A.d.O., Canalli, V.M., Azevedo, C.M.N., Pires, M. "Degradation of pararosaniline (C.I. Basic Red 9 monohydrochloride) dye by ozonation and sonolysis." Dyes Pigments 68, no. 2-3 (2006): 227-234. 
Mascolo, G., Laera, G., Pollice, A., Cassano, D., Pinto, A., Salerno, C., Lopez, A. "Effective organics degradation from pharmaceutical wastewater by an integrated process including membrane bioreactor and ozonation." Chemosphere 78, no. 9 (2010): 1100-1109.

Mason, T.J, Lorimer, J.P., Bates, D.M. "Quantifying sonochemistry: casting some light on a 'black art'." Ultrasonics 30, no. 1 (1992): 40-42.

Mason, T.J., Joyce, E., Phull, S.S., Lorimer, J.P. "Potential uses of ultrasound in the biological decontamination of water." Ultrason. Sonochem. 10, no. 6 (2003): 319-323.

McMurray, J., and Fay, R. Chemistry (6th ed.). Upper Saddle River, NJ: Pearson Prentice-Hall, 2011.

Mendez-Arriaga, F., Torres-Palma, R.A., Petrier, C., Esplugas, S., Gimenez, J., Pulgarin, C. "Ultrasonic treatment of water contaminated with ibuprofen." Water Res. 42, no. 16 (2008): 4243-4248.

Miège, C., Choubert, J.M., Ribeiro, L., Eusèbe, M., Coquery, M.,. "Removal efficiency of pharmaceuticals and personal care products with varying wastewater treatment processes and operating conditions - conception of a database and first results." Water Sci. Technol. 57, no. 1 (2010): 49-56.

Mohajerani, M. "Intensification of advanced oxidation processes for wastewater treatment." $\mathrm{PhD}$ Dissertion, Ryerson University, Toronto, 2012.

Mohajerani, M., Mehrvar, M., Ein-Mozaffari, F. "Using an external-loop airlift sonophotoreactor to enhance the biodegradability of aqueous sulfadiazine solution." Sep. Purif. Technol. 90 (2010): 173-181.

Murthy, Y.S., Subbiah, V., Rao, D.S., Reddy, R.C., Kumar, L.S., Elyas, S.I., Rama Rao, K.G., Gadgill, J.S., Deshmukh, S.B. "Treatment and disposal of wastewater from synthetic drugs 
plant (I.D.P.L.), Hyderabad, Part I - Wastewater characteristics." Indian J. Environ. Health 26 , no.1 (1984): 7- 19.

Mutamim, N.S.A., Noor, Z.Z., Abu Hassan, M.A., Olsson, G. "Application of membrane bioreactor technology in treating high strength industrial wastewater: a performance review ." Desalination 305 (2012): 1-11.

Na, S., Jinhua, C., Cui, M., Khim, J. "Sonophotolytic diethyl phthalate (DEP) degradation with UVC or VUV irradiation." Ultrason. Sonochem. 19 (2012): 1094-1098.

Naddeoa, V., Meric, S., Kassinos, D., Belgiorno, V., Guida, M. "Fate of pharmaceuticals in contaminated urban wastewater effluent under ultrasonic irradiation." Water Res. 43 (2009): 4019-4027.

Nakada, N., Shinohara, H., Murata, A., Kiri, K., Managaki, S., Sato, N., Takada, H. "Removal of selected pharmaceuticals and personal care products (PPCPs) and endocrine-disrupting chemicals (EDCs) during sand filtration and ozonation at a municipal sewage treatment plant." Water Res. 41, no. 19 (2007): 4373-4382.

Nardi, G., Feretti, D., Bracchi, U., Tanzi, M.L., Dorè, F., Francesconi, A., Grottolo, M., Bragonzi, G., Perna, M.C., Monarca, S. "Acque reflue ospedaliere, Valutazione di un trattamento di disinfezione con biossido di cloro." Inquinamento 7 (1995): 77-83.

Nghiem, L., Schafer, A., Elimelech. M. "Pharmaceutical retention mechanisms by nanofiltration membranes." Environ. Sci. Tech. 39, no. 19 (2005): 7698-7705.

Nikolaou, A., Meric, S., Fatta, D. "Occurrence patterns of pharmaceuticals in water and wastewater environments." Anal. Bioanal. Chem. (2007) 387 (2007): 1225-1234. 
Oktem, Y.A., Ince, O., Donnelly, T., Sallis, P., Ince, B. K. "Anaerobic treatment of a chemical synthesis-based pharmaceutical wastewater in a hybrid up-flow anaerobic sludge blanket reactor." Bioresour. Technol. 99 (2008): 1089-1096.

Oktem, Y.A., Ince, O., Donnelly, T., Sallis, P., Ince, B. K. "Determination of optimum operating conditions of an acidification reactor treating a chemical synthesis-based pharmaceutical wastewater." Process Biochem. 41 (2006): 2258-2263.

Oller, I., Malato, S., Sánchez-Pérez, J.A. "Combination of advanced axidation processes and biological treatments for wastewater decontamination-A review." Sci. Total Environ. 409 (2011): 4141-4166.

Onesios, K.M., Yu, J.T., Bouwer, E.J. "Biodegradation and removal of pharmaceuticals and personal care products in treatment systems-a review." Biodegradation 20 (2009): 441466.

Oppenheimer, J., Stephenson, R., Burbano, A., Liu, L. "Characterizing the passage of personal care products through wastewater treatment processes." Water Environ. Res. 79, no. 13 (2007): 1564-2577.

Oppenländer, T. Photochemical Purification of Water and Air, Advanced Oxidation Processes (AOPs);Principles, Reaction Mechanisms, Reactor Concepts. Winheim: Wiley-VCH, 2003.

Oz, N., Ince, O., Ince, B. "Effect of wastewater composition on methanogenic activity in an anaerobic reactor." J. Environ. Sci. Health. A. 39, no. 11-12 (2004): 2029-2042.

Pagano, M., Lopez, A., Volpe, A., Mascolo, G., and Ciannarella, R. "Oxidation of nonionic surfactants by Fenton and H2O2/UV processes." Environ. Technol. 29, no. 4 (2008): 423433. 
Painter, H.A., Loveless, J.E. "Effect of temperature and $\mathrm{pH}$ value on the growth-rate constants of nitrifying bacteria in the activated-sludge process." Water Res. 17, no. 3 (1983): 237-248.

Pereira, V. J., Weinberg, H. S., Linden, K. G., Singer, P. C. "UV degradation kinetics and modeling of pharmaceutical compounds in laboratory grade and surface water via direct and indirect photolysis at 254 nm." Environ. Sci. Tech. 41, no. 5 (2007): 1682-1688.

Pétrier, C., Lamy, M.-F., Francony, A., Benahcene, A., David, B., Renaudin, V., Gondrexon, N. "Sonochemical degradation of phenol in dilute aqueous solutions: Comparison of the reaction rates at 20 and 487 kHz." J. Phys. Chem. 98, no. 41 (1994): 10514-10520.

Qiang, Z., Macauley, J., Mormile, M., Surampalli, R., Adams, C. "Treatment of antibiotics and antibiotic resistant bacteria in swine wastewater with free chlorine." J. Agr. Food. Chem. 54, no. 21 (2006): 8144-8154.

Reungoat, J., Escher, B.I., Macova, M., Argaud, F.X., Gernjak, W., Keller, J. "Ozonation and biological activated carbon filtration of wastewater treatment plant effluents." Water Res. 46, no. 3 (2012): 863-872.

Rizzo, L., Meric, S., Guida, M., Kassinos, D., Belgiorno, V. "Heterogenous photocatalytic degradation kinetics and detoxification of an urban wastewater treatment plant effluent contaminated with pharmaceuticals." Water Res. 43, no. 16 (2009): 4070-4078.

Rosal, R., Rodríguez, A., Perdigón-Melón, J.A., Mezcua, M., Hernando, M.D., Letón, P., GarcíaCalvo, E., (...), Fernández-Alba, A.R. "Removal of pharmaceuticals and kinetics of mineralization by $\mathrm{O}_{3} / \mathrm{H}_{2} \mathrm{O}_{2}$ in a biotreated municipal wastewater." Water Res. 42, no. 14 (2008): 3719-3728.

Rosal, R., Rodríguez, A., Perdigón-Melón, J.A., Petre, A., García-Calvo, E., Gómez, M.J., Agüera, A., Fernández-Alba, A.R. "Occurrence of emerging pollutants in urban 
wastewater and their removal through biological treatment followed by ozonation." Water Res. 44, no. 2 (2010): 578-588.

Sacher, F., Ehmann, M., Gabriel, S., Graf, C., Brauch, H.J. "Pharmaceutical residues in the river Rhine - results of a one-decade monitoring programme." J. Environ. Monit. 10 (2008): 664-670.

Saghafinia, M.S., Emadian, S.M., Vossoughi, M. "Performances evaluation of photo-Fenton process and sonolysis for treatment of penicilin G formulation efflent." Procedia Environ. Sci. 8 (2011): 202-208.

Sanches, S., Barreto Crespo, M.T., Pereira, V.J. "Drinking water treatment of priority pesticides using low pressure UV photolysis and advanced oxidation processes." Water Res. 44, no. 6 (2010): 1809-1818.

Santos, L.H.M.L.M., Araújo, A.N., Fachini, A., Pena, A., Delerue-Matos, C., Montenegro, M.C.B.S.M. "Ecotoxicological aspects related to the presence of pharmaceuticals in the aquatic environment." J. Hazard. Mater. 175, no. 1-3 (2010): 45-95.

Sarria, V., Kenfack, S., Guillod, O., Pulgarin, C. "An innovative coupled solar-biological system at field pilot scale for the treatment of biorecalcitrant pollutants." J. Photoch. Photobio. A 159, no. 1 (2003): 89-99.

Sarria, V., Parra, S., Adler, N., Peringer, P., Benitez, N., Pulgarin, C. "Recent developments in the coupling of photoassisted and aerobic biological processes for the treatment of biorecalcitrant compounds." Catal. Today 76, no. 2-4 (2002): 301-315.

Sayadi, S., Allouche, N., Jaoua, M., Aloui, F. "Detrimental effects of high molecular-mass polyphenols on olive mill wastewater biotreatment" Process Biochem. 35, no. 7 (2000): 725-735. 
Schaar, H., Clara, M., Gans, O., Kreuzinger, N. "Micropollutant removal during biological wastewater treatment and a subsequent ozonation step." Environ. Pollut. 158, no. 5 (2010): 1399-1404.

Schäfer, A.I., Nghiem, L.D., Waite, T.D. "Removal of the natural hormone estrone from aqueous solutions using nanofiltration and reverse osmosis." Environ. Sci. Technol. 37, no. 1 (2003): 182-188.

Schroder, H.F. "Substance-specific detection and pursuit of non-eliminable compounds during biological treatment of waste water from the pharmaceutical industry ." Waste Manage. 19, no. 2 (1999): 111-123.

Scott., J.P., Ollis, D.F. "Integration of chemical and biological oxidation processes for water treatment: review and recommendations." Environ. Prog. 14, no. 2 (1995): 88-103.

Sharma, V.K. "Oxidative transformations of environmental pharmaceuticals by $\mathrm{Cl} 2, \mathrm{ClO} 2, \mathrm{O} 3$, and Fe(VI): kinetics assessments." Chemosphere 73, no. 9 (2008): 1379-1386.

Shirgaonkar, I.Z., Pandit, A.B. "Sonophotochemical destruction of aqueous solution of 2,4,6trichlorophenol." Ultrason. Sonochem. 5, no. 2 (19989): 53-61.

Silva, B.F.D., Jelic, A., López-Serna, R., Mozeto, A.A., Petrovic, M., Barceló, D. "Occurrence and distribution of pharmaceuticals in surface water, suspended solids and sediments of the Ebro river basin, Spain." Chemosphere 85, no. 8 ( 2011): 1331-1339.

Silva, T.F.C.V., Fonseca, A., Saraiva, I., Vilar, V.J.P., Boaventura, R.A.R. " Biodegradability enhancement of a leachate after biological lagooning using a solar driven photo-Fenton reaction, and further combination with an activated sludge biological process, at preindustrial scale" Water Res. 47, no. 10 ( 2011): 3543-3557. 
Sirtori, C., Zapata, A., Oller, I., Gernjak, W., Agüera, A., Malato, S. "Decontamination of industrial pharmaceutical wastewater by combining solar photo-Fenton and biological treatment." Water Res. 43, no. 3 (2009): 661-668.

Sivakumar, R., Muthukumar, K. "Sonochemical degradation of pharmaceutical wastewater." Clean-Soil, Air, Water 39 , no. 2 (2011): 136-141.

Snyder, S., Adham, S., Redding, A., Cannon, F., DeCarolis, J., Oppenheimer, J., Wert, E., Yoon, Y. "Role of membranes and activated carbon in the removal of endocrine disruptors and pharmaceuticals." Desalination 202, no. 1-3 (2007): 156-181.

Song, W., Teshiba, T., Rein, K., O'Shea, K.E. "Ultrasonically induced degradation and detoxification of microcystin-LR (Cyanobacterial Toxin)." Environ. Sci. Technol. 39, no. 16 (2005): 6300-6305.

Sonnenschein, C., Soto, A.M. "An updated review of environmental estrogen and androgen mimics and antagonists." J. Steroid Biochem. 65, no. 1-6 (1998): 143-150.

Sreekanth, D., Sivaramakrishna, D., Himabindu, V., Anjaneyulu, Y. "Thermophilic treatment of bulk drug pharmaceutical industrial wastewaters by using hybrid up flow anaerobic sludge blanket reactor." Bioresour. Tech. 100, no. 9 (2009): 2534-2539.

Strenn, B., Clara, M., Gans, O., Kreuzinger, N. "Carbamazepine, diclofenac, ibuprofen and bezafibrate - investigations on the behaviour of selected pharmaceuticals during wastewater treatment." Water Sci. Technol. 50, no. 5 (2004): 269-276.

Stock, N.L., Peller, J., Vinodgopal, K., Kamat, P.V. "Combinative sonolysis and photocatalysis for textile dye degradation." Environ. Sci. Technol. 34, no. 9 (2000): 1747-1750.

Stumm-Zollinger, E., Fair, G. M. "Biodegradation of steroid hormones." Res. J. Water Pollut. C. 37, no. 11 (1965): 1506-1510. 
Suarez, S., Lema, J.M., Omil, F. "Pre-treatment of hospital wastewater by coagulationflocculation and flotation." Bioresour. Technol. 100 (2009): 2138-2146.

Sumpter, J.P. "Xenoendocrine disrupters-environmental impact." Toxicol. Lett. 102-103 (1998): 337-342.

Tabrizi, G.B., Mehrvar, M. "Integration of advanced oxidation technologies and biological processes: Recent developments, trends, and advances." J. Environ. Sci. Health, A 39, no. 11-12 (2004): 3029-3081.

Takahashi, N., Nakai, T., Satoh, Y., Katoh, Y. "Variation of biodegradability of nitrogenous organic compounds by ozonation" Water Res. 28, no. 7 (1994): 1563-1570.

Tarr, M. Chemical Degradation Methods for Wastes and Pollutants: Environmental and Industrial Applications. New York, NY: Marcel Dekker, 2003.

Tchobanoglous, G., F.L. Burton, and H.D. Stensel. Wastewater Engineering: Treatment, Disposal, and Reuse, 4th Edition. NewYork: McGraw-Hill, Inc., 2003.

Ternes, T.A., Jones, A. Human Pharmaceuticals, Pormones and Fragrances. The Challenge of Micropollutants in Urban Water Managemen. London: IWA, 2006.

Thiele-bruhn, S. "Pharmaceutical antibiotic compounds in soil- a review." J. Plant Nutr. Soil Sci. 166, no.2 (2003): 145-167.

Tezcanli-Guyer, G., Ince, N.H. "Degradation and toxicity reduction of textile dyestuff by ultrasound" Ultrason. Sonochem. 10, no 4-5 (2003):235-240.

Tizghadam, M., Dagot, C., Baudu, M. "Wastewater treatment in a hybrid activated sludge baffled reactor." J. Hazard. Mater. 154 (2008): 550-557. 
Torres, R.A., Pétrier, C., Combet, E., Carrier, M., Pulgarin, C. "Ultrasonic cavitation applied to the treatment of bisphenol A. Effect of sonochemical parameters and analysis of BPA byproducts." Ultrason. Sonochem. 15, no. 4 (2008): 605-611.

Trovó, A.G., Melo, S.A.A., Nogueira, R.F.P. "Photodegradation of the pharmaceuticals amoxicillin, bezafibrate and paracetamol by the photo-Fenton process-Application to sewage treatment plant effluent." J. Photochem. Photobiol., A 198, no. 2-3 (2008): 215220.

Trovó, A.G., Pupo Nogueira, R.F., Agüera, A., Fernandez-Alba, A.R., Malato, S. "Degradation of the antibiotic amoxicillin by photo-Fenton process - Chemical and toxicological assessment." Water Res. 45, no. 3 (2011): 1394-1402.

Van Aken, P., Van Eyck, K., Degrève, J., Liers, S., Luyten, J. "COD and AOX Removal and Biodegradability Assessment for Fenton and O3/UV Oxidation Processes: A Case Study from a Graphical Industry Wastewater" Ozone-Sci. Eng. 35, no. 1 (2013): 16-21.

Velvizhi, G., Venkata Mohan, S. "Biocatalyst behavior under self-induced electrogenic microenvironment in comparison with anaerobic treatment: Evaluation with pharmaceutical wastewater for multi-pollutant removal." Bioresour. Technol. 102, no. 23 (2011): 10784-10793.

Verlicchi, P., Al Aukidy, M., Zambello, E. "Occurrence of pharmaceutical compounds in urban wastewater: Removal, mass load and environmental risk after a secondary treatment $-\mathrm{A}$ review." Sci. Total. Environ. 429 (2012): 123-155.

Verlicchi, P., Galletti, A., Petrovic, M., Barceló, D. "Hospital effluents as a source of emerging pollutants: An overview of micropollutants and sustainable treatment options." J. Hydrol. 389, no. 3-4 (2010): 416-428. 
Vieno, N., Tuhkanen, T., Kronberg, L. "Elimination of pharmaceuticals in sewage treatment plants in Finland." Water Res. 41 (2007): 1001-1012.

Vilar, V.J.P, Moreira., F.C., Ferreira.,A.C.C., Sousa, M.A., Goncalves, C., Alpendurada, M.F., Boaventura, R.A.R. "Biodegradability enhancement of a pesticide-containing bio-treated wastewater using a solar photo-Fenton treatment step followed by a biological oxidation process." Water Res. 46 (2012): 4599-4613.

Vinodgopal, K., Peller J. "Hydroxyl radical-mediated advanced oxidation processes for textile dyes: A comparison of the radiolytic and sonolytic degradation of the monoazo dye Acid Orange 7." Res. Chem. Intermed. 29, no. 3 (2003): 307-316.

Voncina, D.B., Marechal, A.M.L. "Reactive dye decolorization using combined ultrasound/H2O2." Dyes Pigments 59 (2003): 173-179.

Vonga, D., Marotta, R., Napolitano, A., Andreozzi, R., d'lschia, M. "Advanced oxidation of the pharmaceutical drug diclofenac with UV/H2O2 and ozone." Water Res. 38, no. 2 (2004): 414-422.

Watkinson, A., Murby, E., Costanzo, S. "Removal of antibiotics in conventional and advanced wastewater treatment: Implications for environmental discharge and water recycling." Water Res. 41, no. 18 (2007): 4164-4176.

Wei, X., Li, B., Zhao, S., Wang, L., Zhang, H., Li, C., Wang, S. "Mixed pharmaceutical wastewater treatment by integrated membrane-aerated biofilm reactor (MABR) system A pilot-scale study." Bioresour. Technol. 122 (2012): 189-195.

Wu, C., Liu, X., Wei., D., Fan, J., Wang, L. "Photosonochemical degradation of phenol in water." Water Res. 35, no. 16 (2001): 3927-3933. 
Xing, Z., Sun, D. "Treatment of antibiotic fermentation wastewater by combined polyferric sulfate coagulation, Fenton and sedimentation process." J. Hazard. Mater. 168 (2009): $1264-1268$.

Xu, L.J, Chu, W., Graham, N. "Sonophotolytic degradation of dimethyl phthalate without catalyst: Analysis of the synergistic effect and modeling." Water Res. 47 (2013): 19962004.

Yeole, T.Y., Gadre, R.V., Ranade, D.R., "Biological treatment of a pharmaceutical waste." Indian J. Environ. Health 38, no.2 (1996): 95-99.

Yoon, Y., Westerhoff, P., Snyder, S.A., Wert, E.C. "Nanofiltration and ultrafiltration of endocrine disrupting compounds, pharmaceuticals and personal care products." J. Membr. Sci. 270 (2006): 88-100.

Zhang, Y., Love, N., and Edwards, M. "Nitrification in drinking water systems." Crit. Rev. Environ. Sci. Technol. 39, no. 3 (2009): 153-208.

Zhao, H., Jiang, D., Zhang, S., Catterall, K., John, R. "Development of a direct photoelectrochemical method for determination of chemical oxygen demand." Anal. Chem. 76 (2004): 155-160.

Zhou, T., Wu, X., Zhang, Y., Li, J., Lim, T.-T. "Synergistic catalytic degradation of antibiotic sulfamethazine in a heterogeneous sonophotolytic goethite/oxalate Fenton-like system." Appl. Catal. B-Environ. 136-137 (2013): 294-301. 


\section{APPENDICES}

\section{Appendix A. Determination of theoretical TOC and TN of the synthetic pharmaceutical}

wastewater

The carbon source of the synthetic pharmaceutical wastewater, as mentioned in Chapter 3, was from eight components namely 4-aminophenol, paracetamol, phenol, chloramphenicol, benzoic acid, salicylic acid, nitrobenzene and diclofenac whereas nitrogen source was from five chemicals of 4-aminophenol, paracetamol, chloramphenicol, nitrobenzene and diclofenac as found in actual pharmaceutical wastewater. The calculated values of the total organic carbon (TOC) and total nitrogen (TN) of the raw synthetic pharmaceutical wastewater are shown in Table A.1.

For example, calculations for determining TOC and TN for $30 \mathrm{mg} / \mathrm{L}$ nitobenzne $\left(\mathrm{C}_{6} \mathrm{H}_{5} \mathrm{NO}_{2}\right)$ are as follows:

$\mathrm{TOC}_{\text {Nitrobenzene }}\left(\frac{m g \mathrm{C}}{L}\right)=$

$=\frac{\text { Carbon Molecular Weight (in nitrobenzene) }}{\text { Nitrobenzene Molar Mass }} \times$ Concentration of Nitrobenzene in wastewater $\left(\frac{m g}{L}\right)$

$\mathrm{TOC}_{\text {Nitrobenzene }}=\frac{6 \times(12.0107)}{123.06}\left(\frac{m g \mathrm{C}}{m g \text { Nitrobenzene }}\right) \times 30\left(\frac{m g \text { Nitrobenzene }}{L}\right)$

$\mathrm{TOC}_{\text {Nitrobenzene }}=177.55\left(\frac{m g \mathrm{C}}{L}\right)$

and in case of total nitrogen: 
$\mathrm{TN}_{\text {Nitrobenzene }}(m g \mathrm{~N} / L)=$

$=\frac{\text { Nitrogen Molar Mass (in nitrobenzene) }}{\text { Nitrobenzene Molecular Weight }} \times$ Concentration of Nitrobenzene wastewater $\left(\frac{\mathrm{mg}}{\mathrm{L}}\right)$

$\mathrm{TN}_{\text {Nitrobenzene }}=\frac{1 \times(14.0067)}{123.06}\left(\frac{m g \mathrm{~N}}{m g \text { Nitrobenzene }}\right) \times 30\left(\frac{m g \text { Nitrobenzene }}{L}\right)$

$\mathrm{TN}_{\text {Nitrobenzene }}=3.41\left(\frac{m g N}{L}\right)$

The TOC and TN of the synthetic wastewater are the summation of TOC and TN of the components in the wastewater. Table A.1 represents the amount of each component in the wastewater samples and the TOC and TN associates which each component. 
Table A.1.Theoritical TOC and TN of the wastewater

\begin{tabular}{|c|c|c|c|c|c|c|c|c|}
\hline Compound & $\begin{array}{l}\text { Molecular } \\
\text { Formula }\end{array}$ & $\begin{array}{l}\text { Molecular } \\
\text { Weight } \\
(\mathrm{g} / \mathrm{mol})\end{array}$ & $\begin{array}{l}\text { TOC in } 1^{\text {st }} \\
\operatorname{run}(\mathrm{mg} / \mathrm{L})\end{array}$ & $\begin{array}{l}\text { TOC in } 2^{\text {nd }} \\
\operatorname{run}(\mathrm{mg} / \mathrm{L})\end{array}$ & $\begin{array}{l}\text { TOC in } 3^{\text {rd }} \\
\operatorname{run}(\mathrm{mg} / \mathrm{L})\end{array}$ & $\begin{array}{c}\mathrm{TN} \text { in } 1^{\text {st }} \\
\operatorname{run}(\mathrm{mg} / \mathrm{L})\end{array}$ & $\begin{array}{l}\mathrm{TN} \text { in } 2^{\text {nd }} \\
\operatorname{run}(\mathrm{mg} / \mathrm{L})\end{array}$ & $\begin{array}{l}\mathrm{TN} \text { in } 3^{\text {rd }} \\
\operatorname{run}(\mathrm{mg} / \mathrm{L})\end{array}$ \\
\hline 4- Aminophenol & $\mathrm{C}_{6} \mathrm{H}_{7} \mathrm{NO}$ & 109.13 & 4.12844 & 8.256881 & 16.51376 & 0.802752 & 1.605505 & 3.211009 \\
\hline Paracetamol & $\mathrm{C}_{8} \mathrm{H}_{9} \mathrm{NO}_{2}$ & 151.17 & 1.589404 & 3.178808 & 6.357616 & 0.231788 & 0.463576 & 0.927152 \\
\hline Phenol & $\mathrm{C}_{6} \mathrm{H}_{6} \mathrm{O}$ & 94.11 & 9.574468 & 19.14894 & 38.29787 & 0 & 0 & 0 \\
\hline Chloramphenicol & $\mathrm{C}_{11} \mathrm{H}_{12} \mathrm{C}_{12} \mathrm{~N}_{2} \mathrm{O}_{5}$ & 323.132 & 3.065015 & 6.130031 & 12.26006 & 0.650155 & 1.30031 & 2.600619 \\
\hline Benzoic Acid & $\mathrm{C}_{7} \mathrm{H}_{6} \mathrm{O}_{2}$ & 122.12 & 4.303279 & 8.606557 & 17.21311 & 0 & 0 & 0 \\
\hline Salicylic Acid & $\mathrm{C}_{7} \mathrm{H}_{7} \mathrm{O}_{3} \mathrm{Na}$ & 160.11 & 15.08 & 35 & 70 & 0 & 0 & 0 \\
\hline Diclofenac & $\mathrm{C}_{14} \mathrm{H}_{11} \mathrm{C}_{12} \mathrm{NONa}$ & 318.1 & 0.264784 & 0.567568 & 1.135135 & 0.023649 & 0.047297 & 0.094595 \\
\hline Nitrobenzene & $\mathrm{C}_{6} \mathrm{H}_{5} \mathrm{NO}_{2}$ & 123.06 & 4.390244 & 8.780488 & 17.56098 & 0.853659 & 1.707317 & 3.414634 \\
\hline \multicolumn{9}{|l|}{$\begin{array}{l}\text { Theoretical TOC } \\
(\mathrm{mg} / \mathrm{L})\end{array}$} \\
\hline
\end{tabular}

Theoretical TN

$(\mathrm{mg} / \mathrm{L})$

2.56

5.12

10.24 


\section{Appendix B. Calculation of Theoretical COD of the synthetic pharmaceutical wastewater}

For calculation of the theoretical COD, we can consider the reaction of a compound with structural formula of $\mathrm{C}_{\mathrm{x}} \mathrm{H}_{\mathrm{y}} \mathrm{O}_{z}$ with oxygen as follow:

$\mathrm{C}_{x} \mathrm{H}_{y} \mathrm{O}_{z}+\frac{1}{4}(4 x+y-2 z) \mathrm{O}_{2} \rightarrow x \mathrm{CO}_{2}+\frac{y}{2} \mathrm{H}_{2} \mathrm{O}$

From Equation (B.1), the theoretical COD of 1 mole of a compound with formula of $\mathrm{C}_{\mathrm{x}} \mathrm{H}_{\mathrm{y}} \mathrm{O}_{\mathrm{z}}$ is equal to $\frac{1}{4}(4 x+y-2 z)$ moles of $\mathrm{O}_{2}$. Considering the molecular weight of the compound $\mathrm{C}_{\mathrm{x}} \mathrm{H}_{\mathrm{y}} \mathrm{O}_{z}$ as $(12 x+y+16 z) \mathrm{g} / \mathrm{mol}$ and molecular weight of oxygen as $32 \mathrm{~g} / \mathrm{mol}$, it can concluded that the COD of $(12 x+y+16 z)$ grams of compound $\mathrm{C}_{\mathrm{x}} \mathrm{H}_{\mathrm{y}} \mathrm{O}_{z}$ is equal to $\left(\frac{1}{4}(4 x+y-2 z) \times 32\right)=8(4 x+y-2 z)$ gram $\mathrm{O}_{2}$. Therefore, the theoretical COD of the unit mass of the compound $\mathrm{C}_{\mathrm{x}} \mathrm{H}_{\mathrm{y}} \mathrm{O}_{\mathrm{z}}$ can be found by:

$C O D_{\text {theoritich }}=\frac{8(4 x+y-2 z)}{12 x+y+16 z} \frac{m g \mathrm{O}_{2}}{m g C_{x} \mathrm{H}_{y} \mathrm{O}_{z}} \times$ concentration of compound $\frac{m g C_{x} \mathrm{H}_{y} \mathrm{O}_{z}}{L}=\frac{m g \mathrm{O}_{2}}{L}$

As an example for $12.5 \mathrm{mg} / \mathrm{L}$ phenol $\left(\mathrm{C}_{6} \mathrm{H}_{6} \mathrm{O}\right)$, the theoretical COD would be:

$C O D_{\text {phenol }}=\frac{8(4 \times 6+6-2 \times 1)}{(12 \times 6+1+16 \times 1)} \times 12.5=29.78 \frac{\mathrm{mg} \mathrm{O}_{2}}{\mathrm{~L}}$ 
The theoretical COD of a sample would be the summation of the COD of the components inside the sample.

Table B.1.Theoritical COD of the wastewater

\begin{tabular}{llll}
\hline Component & $\begin{array}{l}\text { COD in } \mathbf{1}^{\text {st }} \text { run } \\
(\mathbf{m g} / \mathbf{L})\end{array}$ & $\begin{array}{l}\text { COD in } \mathbf{2}^{\text {nd }} \text { run } \\
(\mathbf{m g} / \mathbf{L})\end{array}$ & $\begin{array}{l}\text { COD in } \\
(\mathbf{m g} / \mathbf{L})\end{array}$ \\
\hline 4- Aminophenol & 11.92 & 23.85 & 47.70 \\
\hline Paracetamol & 4.50 & 9.00 & 18.01 \\
\hline Phenol & 29.78 & 59.57 & 119.14 \\
\hline Chloramphenicol & 9.52 & 19.04 & 38.05 \\
\hline Benzoic Acid & 12.29 & 24.59 & 49.18 \\
\hline Salicylic Acid & 46.66 & 93.33 & 186.66 \\
\hline Diclofenac & 1.05 & 2.10 & 4.21 \\
\hline Nitrobenzen & 10.73 & 21.46 & 42.92 \\
\hline $\begin{array}{l}\text { Theoritical COD } \\
\text { (mg/L) }\end{array}$ & 126.48 & 252.97 & 505.95 \\
\hline
\end{tabular}




\section{Appendix C. Determination of Reynolds number}

In fluid mechanics, the Reynolds number $(R e)$ is a dimensionless number which gives a measure of the ratio of inertial forces to viscous forces and consequently quantifies the relative importance of these two types of forces for given flow conditions. For flow in a pipe or tube, experimental observations show that for fully developed flow, laminar flow occurs when $\operatorname{Re}<$ 2,100 , turbulent flow occurs when $\operatorname{Re}>4,000$, and transient flow occurs when $2,100<\operatorname{Re}<$ 4,000. For flow in a pipe or tube and in a rectangular duct, the Reynolds number is determined by Equation C.1. An example of the Reynolds number calculation is described as follows, the rest of calculations are portrayed in Table C.1.

$R e=\frac{\rho v l}{\mu}=\frac{\rho Q L}{\mu A}$

where,

$R e=$ Reynolds number;

$v=$ mean fluid velocity $(\mathrm{m} / \mathrm{s})$

$L=$ length that the flow is going through or around (diameter of the pipe or tube) (m);

$V=$ volume of the sample $(\mathrm{L})$;

$\mu=$ dynamic viscosity of the fluid (for water at $25^{\circ} \mathrm{C}, \eta=8.98 \times 10^{-4} \mathrm{~kg} / \mathrm{m} . \mathrm{s}$ );

$\rho=$ density of the fluid (for water at $25^{\circ} \mathrm{C}, \rho=1000 \mathrm{~kg} / \mathrm{m}^{3}$ );

$Q=$ volumetric flow rate $\left(\mathrm{m}^{3} / \mathrm{s}\right) ;$ and

$A=$ pipe cross-sectional area $\left(\mathrm{m}^{2}\right)$. 
$A=\frac{\pi D_{0}^{2}}{4}$ or $A=\frac{\pi\left(D_{0}^{2}-D_{i}^{2}\right)}{4}$ for circular shapes

where,

$D_{0}=$ outer diameter $(\mathrm{m})$;

$D_{i}=$ inner diameter $(\mathrm{m})$;

Example for Sonophotoreactor:

Diameter of riser: $0.0972 \mathrm{~m}$

$$
\begin{aligned}
& A=\frac{\pi\left(0.0972^{2}\right)}{4}=0.00742 \mathrm{~m}^{2} \\
& Q=77.7 \frac{\mathrm{mL}}{\min } \times \frac{1 \mathrm{~min}}{60 \mathrm{~s}} \times \frac{1 \mathrm{~L}}{1000 \mathrm{~mL}} \times \frac{1 \mathrm{~m}^{3}}{1000 \mathrm{~L}}=1.295 \times 10^{-6} \frac{\mathrm{m}^{3}}{\mathrm{~s}} \\
& \operatorname{Re}=\frac{\left(1000 \frac{\mathrm{Kg}}{\mathrm{m}^{3}}\right)\left(1.295 \times 10^{-6} \frac{\mathrm{m}^{3}}{\mathrm{~s}}\right)(0.0972 \mathrm{~m})}{\left(8.96 \times 10^{-4} \frac{\mathrm{Kg}}{\mathrm{m} . \mathrm{s}}\right)\left(0.00742 \mathrm{~m}^{2}\right)}=18.9
\end{aligned}
$$

Example for the bioreactor:

Diameter of the inlet pipe: $0.02 \mathrm{~m}$

$$
\begin{aligned}
& A=\frac{\pi\left(0.0972^{2}\right)}{4}=0.00031 \mathrm{~m}^{2} \\
& Q=11.57 \frac{\mathrm{mL}}{\min } \times \frac{1 \mathrm{~min}}{60 \mathrm{~s}} \times \frac{1 \mathrm{~L}}{1000 \mathrm{~mL}} \times \frac{1 \mathrm{~m}^{3}}{1000 \mathrm{~L}}=1.295 \times 10^{-6} \frac{\mathrm{m}^{3}}{\mathrm{~s}}=0.193 \times 10^{-6} \frac{\mathrm{m}^{3}}{\mathrm{~s}} \\
& \operatorname{Re}=\frac{\left(1000 \frac{\mathrm{Kg}}{\mathrm{m}^{3}}\right)\left(0.193 \times 10^{-6} \frac{\mathrm{m}^{3}}{\mathrm{~s}}\right)(0.02 \mathrm{~m})}{\left(8.96 \times 10^{-4} \frac{\mathrm{Kg}}{\mathrm{m} . \mathrm{s}}\right)\left(0.00031 \mathrm{~m}^{2}\right)}=13.9
\end{aligned}
$$


Table C.1.Parameters for calculation of Reynolds number in the aerobic AS, UV/US/ $\mathrm{H}_{2} \mathrm{O}_{2}$, and the combined processes $\left(\mu=8.98 \times 10^{-4} \mathrm{~kg} / \mathrm{m} . \mathrm{s}, \rho=1000 \mathrm{~kg} / \mathrm{m}^{3}\right)$.

\begin{tabular}{|c|c|c|c|c|}
\hline Process & $\mathrm{Q}(\mathrm{mL} / \mathrm{min})$ & $\mathbf{L}(\mathbf{m})$ & $\mathbf{A}\left(\mathrm{m}^{2}\right)$ & $\mathbf{R e}$ \\
\hline Aerobic AS Process & $\begin{array}{l}8.68 \\
11.57 \\
17.36 \\
34.72\end{array}$ & $\begin{array}{l}0.02 \\
0.02 \\
0.02 \\
0.02\end{array}$ & $\begin{array}{l}0.00031 \\
0.00031 \\
0.00031 \\
0.00031\end{array}$ & $\begin{array}{l}10.4 \\
13.9 \\
20.8 \\
41.6\end{array}$ \\
\hline $\mathrm{UV} / \mathrm{US} / \mathrm{H}_{2} \mathrm{O}_{2}$ & $\begin{array}{l}38.88 \\
46.67 \\
58.33 \\
77.77 \\
116.66 \\
233.33\end{array}$ & $\begin{array}{l}0.0972 \\
0.0972 \\
0.0972 \\
0.0972 \\
0.0972 \\
0.0972\end{array}$ & $\begin{array}{l}0.00742 \\
0.00742 \\
0.00742 \\
0.00742 \\
0.00742 \\
0.00742\end{array}$ & $\begin{array}{l}9.4 \\
11.3 \\
14.2 \\
18.9 \\
28.4 \\
56.9\end{array}$ \\
\hline $\begin{array}{l}\text { Combined Sonophotolysis and } \\
\text { Aerobic AS Processes }\end{array}$ & $\begin{array}{l}58.33 \\
17.36\end{array}$ & $\begin{array}{l}0.0972 \\
0.02\end{array}$ & $\begin{array}{l}0.00742 \\
0.00031\end{array}$ & $\begin{array}{l}14.2 \\
20.8\end{array}$ \\
\hline
\end{tabular}




\section{Appendix D. Determination of MLSS and MLVSS}

Total suspended solid and volatile suspended solid were calculated by Equations (3.1) and (3.2) as explained in Section 3.5.3. The method is according to the sections 2540D and 2540E of the Standard Methods (APHA, 1998).

$\operatorname{TSS}$ or $M L S S=\frac{W_{3}-W_{2}-W_{1}}{V}$

And,

$\operatorname{VSS}$ or MLVSS $=\frac{\left(W_{3}-W_{2}-W_{1}\right)-\left(W_{4}-W_{1}\right)}{V}$

where,

$W_{1}=$ Weight of dried aluminum dish (mg);

$W_{2}=$ Weight of dried filter paper $(\mathrm{mg})$;

$W_{3}=$ Sum of weights of solids of the sample, aluminum dish and filter paper after drying at 105 ${ }^{\circ} \mathrm{C}(\mathrm{mg})$

$W_{4}=$ Sum of the weights of the solids of the sample, paper filter and aluminum dish after burning at $550^{\circ} \mathrm{C}(\mathrm{mg})$; and

$V=$ Volume of the sample $(\mathrm{L})$;

For example, in the first day of the acclimatization period, the calculations are shown in Table D.1: 
Table D.1. Calculation of the concentration of MLSS and MLVSS of sludge in the Aerobic AS reactor.

\begin{tabular}{|c|c|c|}
\hline & Sample Description & Result \\
\hline 1 & Weight of aluminum dish & $1.3147 \mathrm{~g}$ \\
\hline 2 & Wight of filter paper & $0.0765 \mathrm{~g}$ \\
\hline 3 & $\begin{array}{l}\text { Sum of weights of solids of the sample, aluminum dish and } \\
\text { filter paper after drying }\end{array}$ & $1.3995 \mathrm{~g}$ \\
\hline 4 & $\begin{array}{l}\text { Sum of the weights of the solids of the sample, paper filter } \\
\text { and aluminum dish after burning }\end{array}$ & $1.3905 \mathrm{~g}$ \\
\hline 5 & Volume of the sample & $5 \mathrm{~mL}$ \\
\hline 6 & MLSS & $1660 \mathrm{mg} / \mathrm{L}$ \\
\hline 7 & MLVSS & $900 \mathrm{mg} / \mathrm{L}$ \\
\hline
\end{tabular}




\section{Appendix E. Determination of standard deviation and relative error}

Each experiment in the current study was replicated three times, and the reported results represent the average value of the obtained results. The standard error of the mean was used as the error bar in this study. The sample standard deviation was used to analyze the accuracy of an experimental measurement for a finite set of experimental data. Sample mean $(\bar{x})$, sample standard deviation $(s)$, and standard error of the mean $\left(S E_{\bar{x}}\right)$ are determined as follows. Standard error of the mean is estimated by the sample estimate of the sample standard deviation divided by the square root of the total sample number.

$\bar{x}=\frac{\sum_{i=1}^{N} x_{i}}{N}$

$S=\sqrt{\frac{\sum_{i=1}^{N}\left(x_{i}-\bar{x}\right)^{2}}{N-1}}$

$S E_{\bar{x}}=\frac{s}{\sqrt{N}}$

where $x_{i}$ is the measurement values of sample $i$; and $N$ is the total number of measurements.

Thus the upper and lower limit of a sample reading can be given as:

Upper limit $=\bar{x}+S E_{\bar{x}}$

Lower limit $=\bar{x}-S E_{\bar{x}}$ 